\author{
Universidade de São Paulo \\ Instituto de Física
}

\title{
Propriedades Físicas que Desencadeiam Alterações Mecânicas em Células Vivas
}

\author{
Marcel Philippi Dorta
}

Orientador: Prof. Dr. Adriano Mesquita Alencar

Dissertação de mestrado apresentada ao Instituto de Física da Universidade de São Paulo, para a obtenção do título de Mestre em Ciências

Banca Examinadora:

Prof. Dr. Adriano Mesquita Alencar (IFUSP)

Prof. Dr. Alexandre da Costa Pereira (Incor/HC/FMUSP)

Prof $^{\mathrm{a}}$. Dr ${ }^{\mathrm{a}}$. Elisabeth Mateus Yoshimura (IFUSP) 


\section{FICHA CATALOGRÁFICA \\ Preparada pelo Serviço de Biblioteca e Informação do Instituto de Física da Universidade de São Paulo}

Dorta, Marcel Philippi

Propriedades físicas que desencadeiam alterações mecânicas em células vivas. São Paulo, 2014.

Dissertação (Mestrado) - Universidade de São Paulo. Instituto de Física. Departamento de Física Geral

Orientador: Prof. Dr. Adriano Mesquita Alencar

Área de Concentração: Física

Unitermos: 1.Processamento de imagens; 2. Fractais; 3. Reologia; 4. Microscopia confocal. 
"Sou eu próprio uma questão colocada ao mundo e devo fornecer minha resposta; caso contrário, estarei reduzido à resposta que o mundo me der." Carl Gustav Jung, Uma resposta ao nosso tempo. 


\section{Agradecimentos}

Gostaria de iniciar agradecendo do fundo do meu coração a Deus e a minha família. Meus irmãos, Renato e Renan, a minha mãe, Tânia e ao meu pai, Celso, que fisicamente não pôde presenciar este término. Mas eu sei que hoje ele se encontra em um lugar muito melhor do que qualquer um de nós pode imaginar, e que de lá, ele está muito feliz por mais esta etapa cumprida. Agradeço ao apoio de todos, especialmente a minha mãe que me deu toda a força e condição para que eu pudesse estar aqui hoje. Tudo isso é graças a você mãe, ao seu carinho, ao seu amor, a sua dedicação e por você ter acreditado em mim. Se eu pudesse, daria metade do meu diploma para você, porém, como isto não é possível, te digo que você é importante de mais pra mim e que eu te amo muito.

Agradeço aos meus amigos e parentes, que mesmo estando longe sempre me deram todo o apoio e carinho para que eu conseguisse superar todas as dificuldades do caminho. Vocês foram muito importantes pra mim. Eram vocês que sempre me faziam lembrar da minha terrinha querida, que me ligavam pra saber como eu estava, que me contavam coisas engraçadas, quando por aqui a situação não era das mais felizes. Muito obrigado por vocês existirem na minha vida.

Já aqui em São Paulo, uma das coisas que mais me ajudou e iluminou meu caminho foi o Grudo de Estudos Espíritas Mensageiros da Luz. Esses amigos, essa grande família que nós formamos foi maravilhosa. Vou guardar todos estes momentos no fundo do coração, para o resto da minha vida. Assim, agradeço aos amigos, Ney, José, Rose, Geraldo, Jaqueline, Juliana, Paula, Pettterson, Daniela, Ana Costa, a queridíssima Ana Toscano, enfim, a todos que fazem parte desta casa. Muito obrigado por todas as conversas, conselhos, estudos, diversão e oportunidade de elevação espiritual. Vocês são muito importantes para minha vida, e me ajudaram muito nessa caminhada.

Agradeço a todas as amizades feitas nestes últimos anos da minha vida. A amizade pra mim é algo muito importante e sempre me deu motivos pra sorrir e pra acreditar que a vida vale a pena ser vivida. Agradeço, em especial, com todo o carinho do mundo a Karina, pela convivência quase constante durante todo este tempo morando aqui em São Paulo. Só Deus, com suas leis de infinito amor, sabe o quanto esta amizade significou pra mim, o quanto eu aprendi e como todos estes momentos vividos irão 
repercutir no decorrer da minha vida. Agradeço sempre, por você ter entrado na minha vida e por ser esta pessoa tão especial que só você sabe ser.

Agradeço aos amigos formados no decorrer do curso de Mestrado. Ao, Bruno, André, Alexsandro, vulgo Gaúcho e aos amigos de sala, Vinicius e Fabris. Agradeço em especial este último por todos os bate papos e conselhos de caráter científico, que me ajudaram muito a dar andamento ao meu trabalho. Agradeço a todos os amigos de grupo de pesquisa, Alexandre, Mariana Sacrini, Mariana Menegon, Marcia, Wagner, Juan, Matheus e a Diana, ou Dianitta. Sou muito grato pela oportunidade de ter conhecido todos vocês e pelos bons e maus momentos que passamos juntos nestes últimos anos.

Agradeço muito ao meu orientador, Prof. Adriano, por ter aberto as portas do grupo para mim, por todo o apoio, pela dedicação, por sempre querer ajudar e por todos os conselhos. Sei que se hoje pude aumentar meu leque de conhecimento, me tornando mais capaz de encarar o mundo profissional e cientifico, foi graças a você professor. Em nome do grupo, agradeço por sempre procurar nos ajudar no que for preciso, e pelo esforço constante de tentar deixar o ambiente de convivência do grupo o mais agradável possível, fazendo com que nos sentíssemos felizes trabalhando.

Agradeço a FAPESP pelo apoio financeiro, tanto com relação a bolsa quanto ao recurso para a pesquisa. Graças aos recursos em forma de auxilio a pesquisa pude me manter em São Paulo e obter este título. Por fim, agradeço ao Instituto de Física pelo espaço físico disponibilizado para que eu pudesse realizar a pesquisa com as melhores condições possíveis. 


\section{Resumo}

Todos os seres vivos compartilham uma característica comum na sua composição estrutural, a célula. No corpo humano, as células vasculares de músculo liso são fundamentais para o bom funcionamento dos vasos arteriais. A principal função dessas células é contrair e regular o calibre desses vasos, a pressão sanguínea e a distribuição do fluxo de sangue. Devido a isto, alterações mecânicas sofridas por estas células acarretam modificações estruturais nos vasos, podendo levar à hipertensão, vasoespasmo e arteriosclerose. O principal objetivo do nosso trabalho foi o de desenvolver uma nova plataforma de análise de imagens de células vasculares para caracterizar suas propriedades estruturais. Em nossa plataforma, analisamos parâmetros estruturais de células vasculares de músculo liso de diferentes leitos arteriais, com as fibras de actina evidenciadas com marcadores fluorescentes, obtidas por microscopia confocal. Estes parâmetros são: o Índice de Alinhamento das fibras de actina da imagem, a distribuição de comprimento dessas fibras e sua dimensão fractal. Mostramos que com esses parâmetros somos capazes de comparar células de leitos arteriais diferentes de forma quantitativa, assim como, correlacionar esses parâmetros com suas propriedades mecânicas. 


\begin{abstract}
All living organisms share a unique characteristic in their structural composition, the cell. In the human body, vascular smooth muscle cells are fundamental for the ideal functioning of the arterial vessels. The main function of these cells is to contract and regulate these vessels caliber, as well as the blood pressure and flow distribution of blood. Due to the exposed above, mechanical alterations suffered by these cells cause structural modifications in vessels, which may lead to hypertension, vasospasm and atherosclerosis. The main objective of our research was to develop a new framework of image analysis for vessel cells in order to characterize their structural properties. In our framework we analyzed structural parameters of vascular smooth muscle cells from different arterial sites, with actin fibers labeled with fluorescent markers, obtained by confocal microscopy. These parameters are: the actin fibers alignment index of the image, the length distribution of these fibers and their fractal dimension. We presented that with these parameters we are able to quantitatively compare cells in different arterial sites as well as correlate these parameters with their mechanical properties.
\end{abstract}




\section{Sumário}

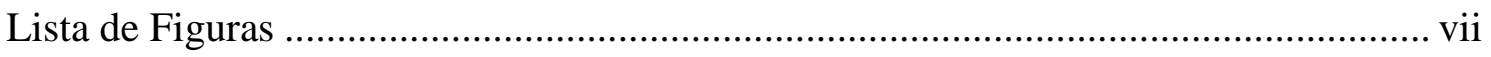

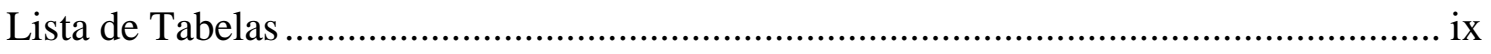

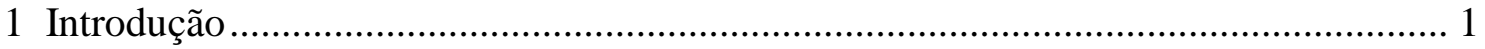

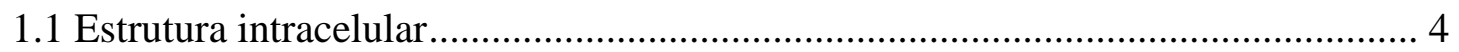

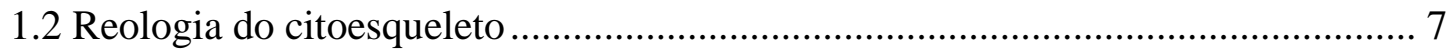

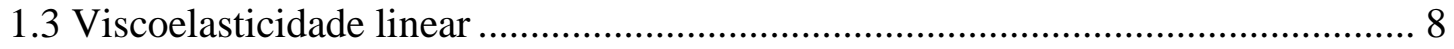

1.4 Citometria óptica magnética de rotação.............................................................. 13

1.5 Caracterização mecânica de CVML via técnica de OMTC .................................... 16

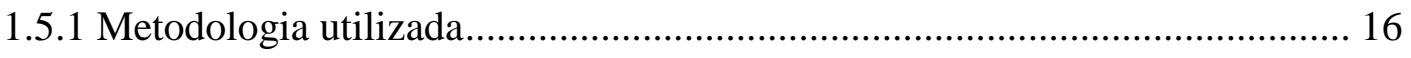

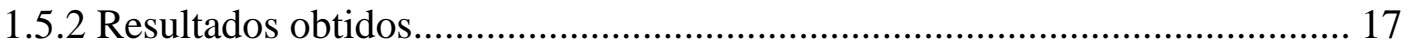

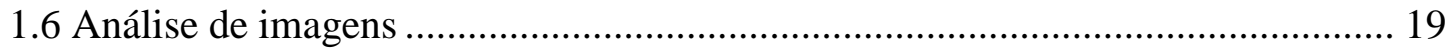

1.6.1 Microscopia de fluorescência .............................................................. 21

1.6.2 Processos de identificação de bordas em uma imagem ................................ 24

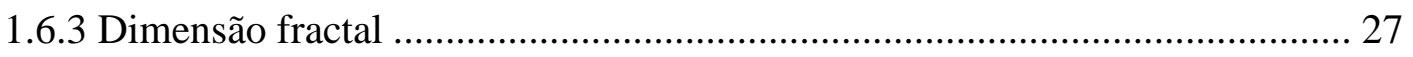

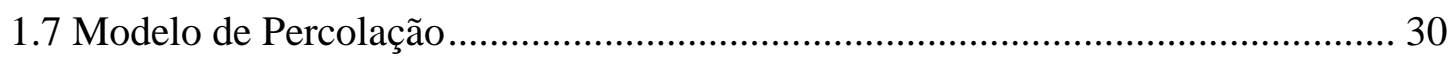

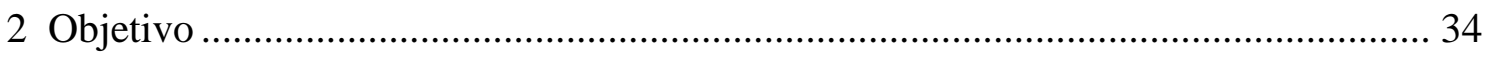

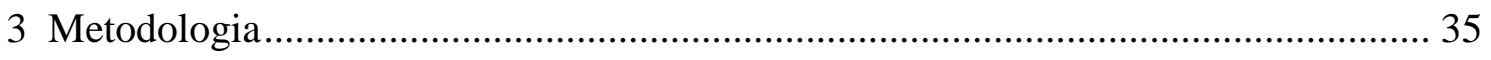

3.1 Processamento e análise das imagens ................................................................... 35

3.2 Quantificação da Dimensão fractal .................................................................... 36

3.3 Quantificação do Índice de Alinhamento ......................................................... 38

3.4 Processamento para quantificação da distribuição de comprimento das fibras .... 40

3.5 Testes de aplicabilidade da metodologia desenvolvida .................................... 43

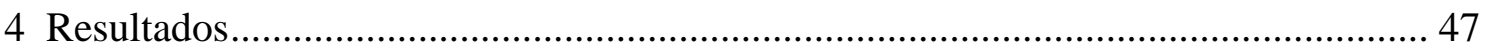

4.1 Caracterização morfológica de células vasculares de músculo liso: Índice de alinhamento de Dimensão fractal. 
4.2 Caracterização morfológica de células vasculares de músculo liso: Probabilidade de distribuição do comprimento das fibras de actina.

5 Discussão e Considerações Finais ......................................................................... 58

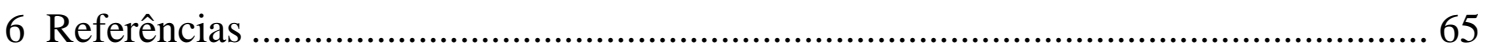

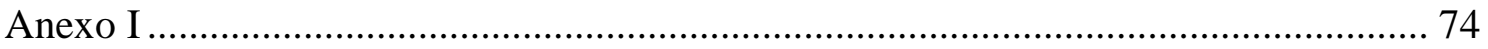




\section{Lista de Figuras}

Figura 1: Principais componentes do citoesqueleto. ................................................... 5

Figura 2: Módulo de Young de alguns materiais comuns........................................... 8

Figura 3: Cisalhamento de um fluido e de um sólido.................................................... 10

Figura 4: Modelo de Maxwell representado por uma mola associada em série com um amortecedor.

Figura 5: Esquema da técnica do OMTC.

Figura 6: Comportamento da rigidez média $Z G$ das CVML..................................... 18

Figura 7: Esquema representativo de uma imagem, vista por um computador.

Figura 8: Comparação entre uma imagem obtida por microscopia de fluorescência convencional (A) e por confocal (B).

Figura 9: Esquema do funcionamento da fluorescência por um microscópio confocal. 23

Figura 10: Aplicação da FFT em imagens de tecidos normais e malignos obtidos por MSH.

Figura 11: Orientação do citoesqueleto sobre indução de estiramento em células confluentes.

Figura 12: Dimensão Euclidiana e topológica para diversos tipos de objetos.

Figura 13: Esquema ilustrativo para definir percolação e seus agregados.

Figura 14: Teste do limiar de corte

Figura 15: Eliminação de ruído remanescente na identificação do eixo principal.

Figura 16: Comparação entre o processo de esqueletização, utilizada pelo ImageJ, e de identificação do eixo principal, desenvolvido pelo nosso algoritmo.

Figura 17: Teste dos parâmetros $L c, N \min$ e $N \max$, para o cálculo da $D f$ das células.

Figura 18: Teste do algoritmo em imagens artificiais 
Figura 19: Variação da quantidade, $Q$, para remoção de pequenos pixels interpretados como ruído remanescente do processo de identificação do eixo principal das fibras.... 46

Figura 20: Estimativa da $D f$ obtida pelo método de box counting. com o tamanho, $L$,

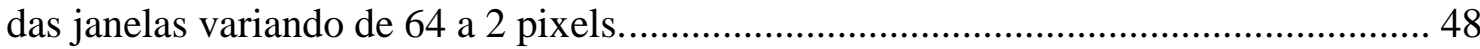

Figura 21: Etapas do processo das imagens. ........................................................... 50

Figura 22: Comportamento do IA com a variação do tamanho da lado, $L$, da janela

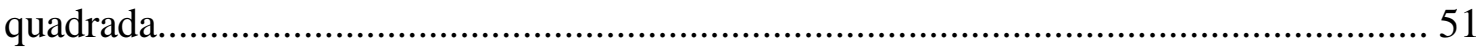

Figura 23: Comportamento do IA de da $D f$ de acordo com o leito arterial.

Figura 24: Esquema ilustrativo do cálculo do perímetro das fibras selecionadas.

Figura 25: Frequências relativas de comprimentos normalizados das fibras, obtidas pela imagem das células de cada artéria (Femoral, Renal, Aorta Abdominal, Carótida, Mamária, Aorta Torácica e Coronária). 55

Figura 26: Gráfico com frequência relativa em escala logarítmica, ilustrando o comportamento para filamentos de comprimentos longos.

Figura 27: Comparação entre a predição teórica da distância relativa entre os sítios de uma rede no modelo de percolação, com a distribuição relativa de filamentos de uma imagem publicada na internet. 


\section{Lista de Tabelas}

Tabela 1: Frequência relativa de comprimentos curtos por leito arterial. .56

Tabela 2: Comparação entre ZG, Frequência relativa de comprimentos curtos, $D_{f}$ e IA .62

Tabela 3: Diferenças estruturais e anatômicas entre as CVML estudadas. .63 


\section{Introdução}

Células vasculares de músculo liso (CVML) são fundamentais para o bom funcionamento dos vasos arteriais no corpo [1]. Estas células compõem a maior parte da parede do vaso sanguíneo e sua principal função é contrair e regular o calibre desses vasos, a pressão sanguínea e a distribuição do fluxo de sangue [2]. As CVML possuem uma plasticidade singular e podem sofrer mudanças no fenótipo em resposta a estímulos locais no ambiente [3].

As CVML possuem características distintas em diferentes artérias, uma vez que o calibre dos vasos varia ao longo da árvore arterial, assim como o fluxo sanguíneo [4,5]. Em artérias saudáveis, as CVML possuem uma forma fusiforme característica, sendo menos pronunciadas em artérias mais elásticas e mais alongadas e bem definidas em células musculares. Este alongamento no formato das células musculares possui a função de facilitar a modulação do tônus nas artérias, nas quais a resposta ao fluxo e pressão sanguínea é importante [5]. Entretanto, quando expostas a danos ambientais ou fisiológicos, as CVML podem alterar sua contratilidade e produção de matriz extracelular (MEC), tornando-se proliferativas e migratórias. Esta mudança desempenha um papel importante na quantidade de alterações vasculares, tais como: hipertensão, vasoespasmo e arterioesclerose, corroborando para que alterações mecânicas nas CVML acarretem modificações estruturais nos vasos, podendo gerar quadros patológicos [5,6].

A mecânica celular tem despertado interesse em várias áreas científicas, principalmente na interface entre Física e Fisiologia [7-9], tendo em vista que o entendimento da mecânica celular que leva a modificações estruturais pode afetar o crescimento de tecido [10,11], formação de tubos vasculares [12,13], migração celular [5,8], assim como levar a quadros patológicos $[14,15]$. Este avanço na área de Fisiologia Molecular levou ao desenvolvimento de novas técnicas experimentais e teóricas para a medição e análise de propriedades mecânicas de células vivas. Dentre as técnicas experimentais, podemos citar: o método da pinça óptica [16,17], aspiração por micropipeta [18-20], microscopia de força atômica [21-23], microscopia de força de tração [24-26], citometria óptica magnética de rotação [15,27-30], entre outras. 
O desenvolvimento destas técnicas experimentais levou à criação de uma vasta gama de modelos matemáticos para descrever a reologia do citoesqueleto e sua mecânica [30]. Estas técnicas experimentais frequentemente induzem uma perturbação mecânica na célula, impondo uma deformação ou aplicando uma força e observando como a célula responde a isto. Isto deu origem a uma série de teorias para descrição da mecânica de células vivas e modelagem do seu citoesqueleto, tais como: os modelos mecânicos elásticos, viscoelásticos e porosos [17,29,31-33]; modelos baseados na teoria de materiais vítreos moles (SGM do inglês "soft glassy material") [17,34,35]; modelo de tensegriy, que parte da premissa da existência da pré-tensão celular exercidas pelo citoesqueleto [36-39]; modelos baseados na teoria de percolação na qual os filamentos que compõem o citoesqueleto devem estar conectados de uma extremidade a outra da célula, para que esta possa exercer suas funções mecânicas [29,40].

Em trabalhos recentes do nosso grupo, verificou-se que CVML de diferentes localidades na árvore arterial, ou seja, de diferentes leitos arteriais, apresentam propriedades mecânicas distintas [41]. Para tal, mediu-se a viscoelasticidade das CVML de diferentes leitos pela técnica de citometria óptica magnética de rotação (OMTC do inglês "Optical Magnetic Twisting Cytometry") ${ }^{1}$. Esta técnica visa quantificar propriedades elásticas e viscosas do esqueleto celular, ou citoesqueleto. Basicamente, microesferas ferromagnéticas, magnetizadas horizontalmente, são aderidas no citoesqueleto da célula e submetidas a um campo magnético oscilatório vertical, do qual pode-se extrair a viscoelasticidade da célula observando a movimentação das esferas $[42,43]$.

Este trabalho não só mostrou a eficiência da técnica em caracterizar células de diferentes artérias do corpo, assim como, deixou em aberto a seguinte questão: qual é a alteração estrutural que resulta em uma alteração viscoelástica na célula? $O$ principal objetivo deste trabalho é responder tal pergunta. Para isso, desenvolvemos uma nova plataforma de análise de imagens de CVML com o objetivo de caracterizar suas propriedades estruturais. Esta plataforma é composta de funções específicas, organizadas em um algoritmo que visa quantificar o alinhamento e distribuição de comprimento de fibras de actina evidenciadas na imagem das células, assim como, alterações no seu formato. Estes tipos de análises de imagens podem servir como uma

\footnotetext{
${ }^{1}$ Um dos grupos pioneiros no desenvolvimento desta técnica foi o grupo da Harvard School blichHeath, arvard University - USA, liderada pelo Prof. Dr. Jeffrey J. Fredberg, o qual mantemos colaborações científicas.
} 
poderosa ferramenta de estudo das propriedades mecânicas e estruturais de células vivas.

Um progresso considerável pode ser constatado nos últimos anos no desenvolvimento de ferramentas de análise de imagens para quantificar mudanças dinâmicas e estruturais tanto em células como em tecidos [44-54]. Os procedimentos comumente utilizados na literatura científica para estes tipos de análises, consistem em: quantificação do alinhamento e comprimento de fibras por análise de Fourier ou identificação de bordas $[45,46,55]$ e mudanças na morfologia do citoesqueleto por análise da Dimensão fractal $\left(D_{f}\right)[54,56,57]$.

Um dos aspectos que faz a quantificação do alinhamento das fibras ser importante é, por exemplo, o fato de que no corpo humano os tecidos musculares dependem do alinhamento de sua matriz extracelular para desempenhar sua função mecânica. A quantificação do alinhamento das fibras das células e da matriz extracelular é determinante no entendimento de como este alinhamento afeta as funções celulares [50]. A análise da $D_{f}$ pode fornecer uma informação adicional sobre a morfologia celular e sua relação com o alinhamento das fibras. Enquanto que o cálculo do comprimento das fibras, além de estar vinculado com mudanças morfológicas, também nos fornece um elo com o modelo teórico de percolação para as CVML.

Para que estas análises possam ser realizadas de forma confiável é necessário a utilização de uma técnica de microscopia capaz de evidenciar a estrutura de interesse com precisão. A utilização de técnicas de microscopia aliadas a uma análise de imagem quantitativa fornece subsídios consideráveis para a interpretação de resultados experimentais [47,48,58-60]. Técnicas de microscopia de fluorescência como, por exemplo, a microscopia confocal, tem sido de fundamental importância para o estudo de células e do funcionamento de funções moleculares [61].

Por fim, nossa plataforma de análise de imagens se diferencia das demais no sentido de fornecer índices que podem ser usados como parâmetro de comparação entre imagens. Para tal, nossa plataforma faz uma análise automatizada, independente do usuário do programa, de parâmetros estruturais da célula que são: o Índice de Alinhamento (IA) das fibras de actina da imagem, a distribuição de comprimento dessas fibras e sua $D_{f}$. 


\subsection{Estrutura intracelular}

Todo ser vivo compartilha uma característica comum na sua composição estrutural, a célula [62]. Podemos dizer que as células são as unidades funcionais básicas da vida, compostas por inúmeros componentes com características mecânicas distintas [30]. Para exercer suas funções, as células controlam suas atividades intra e extracelulares, que constituem basicamente de respostas mecânicas e bioquímicas a forças externas dirigidas a elas.

O comportamento mecânico das células depende da propriedade e do arranjo dos elementos estruturais, que podem ser vistos como uma rede fibrosa, ou rede de filamentos, coletivamente conhecida como citoesqueleto [63]. A maioria dos filamentos estruturais na célula estão interligados para formar uma rede tridimensional, onde filamentos individuais constituintes desta rede se distribuem na célula de forma emaranhada, o que reflete, em parte, sua resistência ao ser flexionada [64]. O citoesqueleto, juntamente com a membrana celular, fornece uma integridade estrutural para manter seu formato, muitas vezes necessário para que as células possam se comunicar entre si e realizar suas funções [30]. Portanto, os filamentos do citoesqueleto, juntamente com outras estruturas, contribuem para a resposta da mecanotransdução, fenômeno este que envolve a sensibilidade da célula em responder a um estímulo mecânico [65].

A rede fibrosa do citoesqueleto além de desempenhar um importante papel nas funções celulares, como migração, adesão e mecanotransdução, também é responsável pela rigidez da mesma [66]. Os principais componentes da rede do citoesqueleto são os filamentos intermediários, os microtúbulos, as fibra de actina, e as ligações cruzadas de proteínas. Estes filamentos de proteínas são responsáveis por manter as propriedades estruturais e a motilidade celular [30,35]. Uma representação esquemática dos filamentos que compõe o citoesqueleto pode ser visto na Figura 1. 

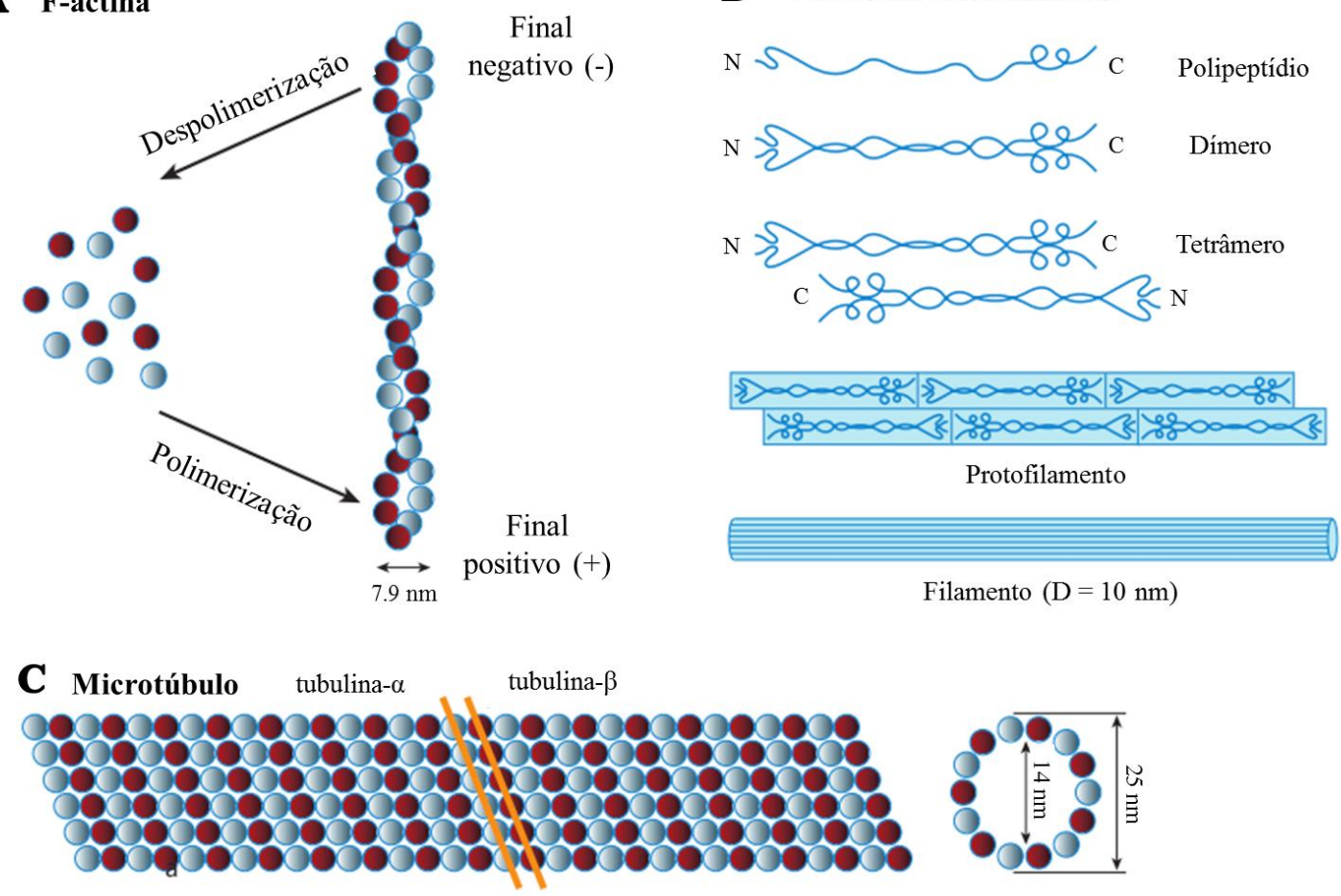

Figura 1: Principais componentes do citoesqueleto. Em A temos as F-actina, em $\mathbf{B}$ os filamentos intermediários e em $\mathbf{C}$ os microtúbulos (Figura adaptada de [30]).

Os filamentos intermediários são ligeiramente mais largos que as fibra de actina e possuem uma estrutura hierárquica mais complexa. Estes filamentos são compostos de diferentes monômeros de proteínas entrelaçados como uma hélice [64]. Os dímeros se arranjam por ligações não covalentes em uma rede alternada de tetrâmeros conectados pelos seus pontos finais formando assim, os protofilamentos, conforme Figura 1. Estes, por sua vez, formam feixes em estruturas do tipo corda, contendo em torno de oito protofilamentos em formato quase cilíndrico com diâmetro de $10 \mathrm{~nm}$, aproximadamente [30,64]. Os filamentos intermediários também contribuem para a elasticidade da célula. Sua rede exibe uma elasticidade não-linear pronunciada, similar a que é observada nas fibras de actina. Estas propriedades elásticas da rede de filamentos intermediários foram investigadas por Yi-Chia Lina et al. em 2010, onde foram analisados dois tipos de filamentos intermediários com propriedades mecânicas similares, vimentina e neurofilamento [67].

Os microtúbulos constituem outro importante componente do citoesqueleto e tem sido verificado seu envolvimento em uma variedade de processos celulares, atuando como um canal para condução dos motores celulares assim como, na organização da 
divisão celular [30,63]. Os microtúbulos são polímeros ocos com diâmetro interno e externo de 14 e $25 \mathrm{~nm}$, respectivamente, compostos de monômeros de tubulina- $\alpha$ e $\beta$ em um arranjo helicoidal, conforme Figura 1 [30,68]. Muitas pesquisas foram feitas sobre as propriedades dos microtúbulos no qual podemos destacar o modelo mecânico celular de Tensigrity, o qual se baseia na premissa de que os microtúbulos realizam compressão que balanceia o estresse contráctil exercido pelas fibras de actina dando estabilidade para a célula. Mais informações a respeito do modelo de Tensegrity e das funções dos microtúbulos e das fibras de actina podem ser encontras nas referências $[25,38,39,69-72]$.

As fibras de actina são polímeros polares com uma torção helicoidal, com diâmetro de 7 a 9 nm, e dois pontos finais que são extremamente diferentes, chamados de barbed e pointed. O ponto final barbed é o mais dinâmico e se alonga 10 vezes mais rápido que o final, pointed [73]. A actina é vista como sendo o componente estrutural primário das células, constituindo $10 \%$ de toda proteína da maioria das células [30]. Sua alta concentração celular torna-a a proteína mais abundante da Terra [74]. As fibras de actina são essenciais para dar suporte mecânico interno para a célula, fornecendo caminhos para a movimentação interna de materiais e dando força para locomoção celular.

As proteínas de ligações cruzadas ligam as F-actina umas às outras formando géis elásticos ou conjuntos de estruturas tais como: fibras de estresse e filopódia [32]. As fibras de actina têm sido caracterizadas por uma variedade de técnicas experimentais. Seus filamentos são rígidos, tendo um comprimento de persistência na ordem de aproximadamente $10 \mu \mathrm{m}$ em solução aquosa, e um efetivo módulo de Young, determinado pela sua rigidez de deflexão e raio [30].

Devido à importância da actina e dos demais filamentos que compõem o citoesqueleto celular, o conhecimento básico de sua reologia é essencial para o entendimento de suas propriedades mecânicas. Portanto, aprofundaremos o conceito de reologia e a aplicação de técnicas experimentais para o estudo da mecânica do citoesqueleto, especificamente na técnica do OMTC. 


\subsection{Reologia do citoesqueleto}

O termo reologia significa o estudo da deformação e fluidez da matéria, ou seja, é o estudo de como materiais complexos fluem e se deformam sob algum tipo de estresse [75,76]. Devido à baixíssima rigidez e pequeno tamanho da célula, as forças mecânicas e as deformações são muito pequenas, na faixa de pico-Newtons e nanômetros, respectivamente [28]. A razão entre a tensão e a deformação relativa de um material, é uma constante chamada de módulo de Young [77]. A Figura 2, mostra o valor do módulo de Young para alguns materiais. Nela, podemos ver que a célula é extremamente mole, com um módulo de Young de muitas ordens de grandeza menor do que a maioria dos materiais comuns.

Quando materiais moles, a esse nível, cerca de $10^{3} \mathrm{~Pa}$ conforme Figura 2, são tensionados, suas microestruturas, tanto armazenam quanto dissipam a energia de deformação de uma forma que pode depender da frequência, fazendo com que, neste caso, a viscosidade e a elasticidade também dependam. As propriedades reológicas de materiais moles determinam sua fluidez e comportamento, fornecendo um vislumbre da sua composição microestrutural [76]. Quantificações mais precisas de medidas mecânicas de células vivas tornaram-se possíveis apenas com desenvolvimento de técnicas microreológicas em décadas recentes, tais como: pinça magnética, pinça óptica, microscopia de força atômica e de tração, OMTC, dentre outras [17,28-30,76]. Aqui, abordaremos especificamente a técnica de OMTC e os conceitos físicos que levaram ao desenvolvimento de tal técnica. Esta técnica se diferencia das demais pela sua capacidade de analisar uma quantidade grande de células, em torno de duzentas, por experimento, fornecendo uma quantidade amostral significativa para análise dos resultados. 


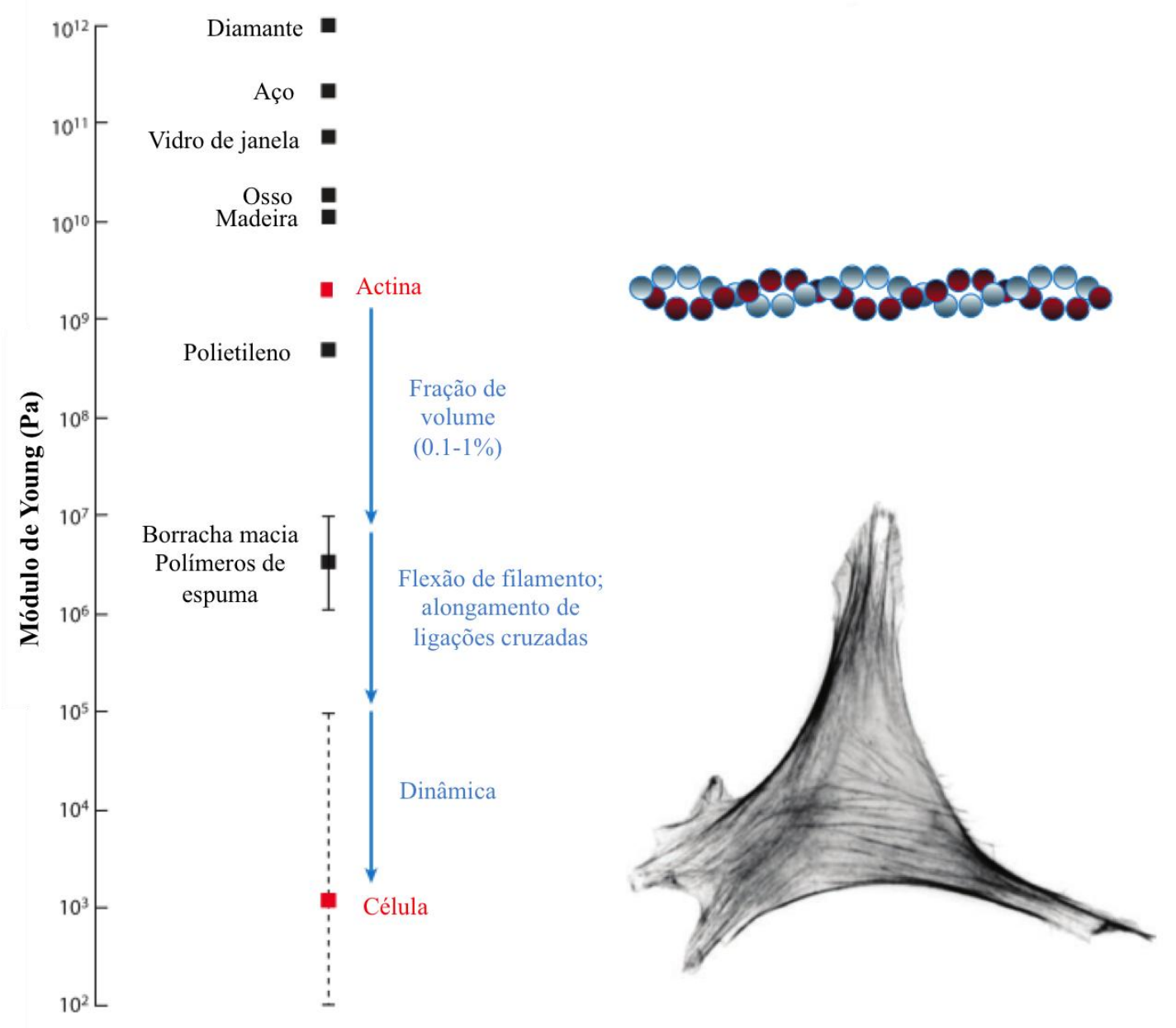

Figura 2: Módulo de Young de alguns materiais comuns. A célula apresenta um módulo de Young muitas ordens de grandeza menor do que alguns materiais típicos, o que a torna extremamente mole. A Factina, isoladamente, tem uma alta rigidez e é a principal proteína que constitui a célula, entretanto, quando colocada no formato de malha conectada com outros componentes do citoesqueleto, forma uma estrutura com a rigidez de géis moles. A imagem ao lado corresponde ao citoesqueleto de uma célula de fibroblastos NIH-3T3 (imagem adaptada de [28]).

\subsection{Viscoelasticidade linear}

Dependendo da abordagem experimental e da escala de tempo, as células apresentam ambas as propriedades: elásticas do tipo sólido e viscosa do tipo líquido [28]. Podemos definir viscosidade e elasticidade utilizando a Figura 3, onde em A, temos uma camada de um líquido qualquer entre duas placas paralelas de área $A_{b}$, a uma distância $d$ uma da outra. Podemos definir a taxa de deformação de cisalhamento, $\dot{\lambda}$, quando aplicamos uma força constante, $F$, na placa superior, que começa a se mover 
com velocidade constante, $v$, relativa à placa inferior na direção paralela à superfície, da seguinte forma:

$$
\frac{d \lambda}{d t}=\dot{\lambda}=\frac{v}{d}
$$

onde a tensão de cisalhamento, $\sigma$, é dada por

$$
\sigma=-\frac{F}{A_{b}}
$$

Assim, a viscosidade do líquido, $\eta$, pode ser definida por:

$$
\eta=-\frac{\sigma}{\dot{\lambda}}
$$

O sinal de negativo é escolhido para dizer que a tensão de cisalhamento, $\sigma$, é exercida pelo sistema sobre o meio externo [78]. A elasticidade pode ser deduzida pela Figura 3(B), onde temos um pedaço de material sólido com área superior e inferior $A_{b} \mathrm{e}$ altura $h$. Quando aplicamos uma força de cisalhamento, $F$, constante, na superfície superior, a posição relativa das duas superfícies pode ser deslocada de uma distância, $s$. Então, a deformação de cisalhamento, $\lambda$, é dada por:

$$
\lambda=\frac{s}{h}
$$

e a tensão de cisalhamento é dada por:

$$
\sigma=-\frac{F}{A_{b}}
$$

De acordo com a definição de um sólido Hookiano, a tensão é linearmente proporcional à deformação

$$
\sigma=G \lambda
$$


onde a constante $G$ é o módulo de Young do sólido, comentado anteriormente.
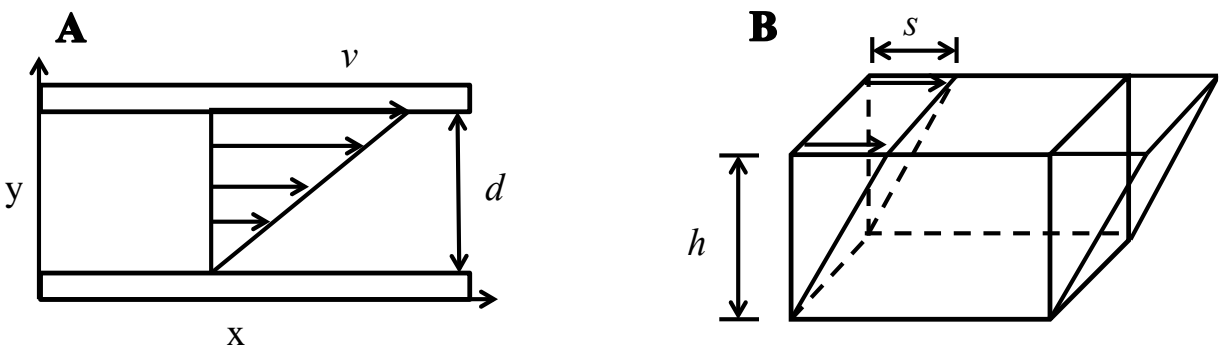

Figura 3: Cisalhamento de um fluido e de um sólido. A: cisalhamento de um fluido entre duas placas planas paralelas separadas por uma distância $d$, onde a placa superior se move com uma velocidade $v$ com relação à placa inferior. B: cisalhamento de um bloco sólido retangular, com altura $h \mathrm{e}$ um deslocamento $s$ da superfície superior com relação à inferior.

Podemos representar o comportamento de um polímero viscoelástico utilizando um modelo mecânico, conhecido como modelo de Maxwell. Neste modelo podemos imitar um material viscoelástico utilizando uma mola e um amortecedor para representar a propriedade elástica e viscosa do material, respectivamente. A mola e o amortecedor estão associados em série, sendo a mola um sólido do tipo de Hooke com comprimento de repouso $S_{0}$. Este sistema, quando deformado por uma força, tem por consequência uma dissipação de energia pelo amortecedor e um armazenamento de energia pela mola [78]. O esquema do modelo de Maxwell pode ser visto na Figura 4.

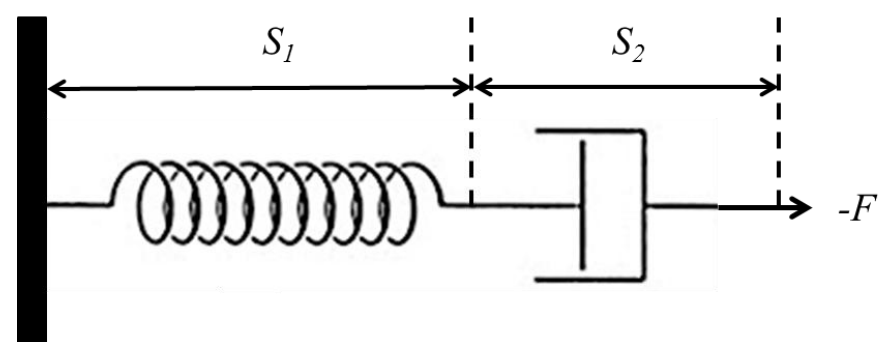

Figura 4: Modelo de Maxwell representado por uma mola associada em série com um amortecedor.

Dividindo o comprimento total do sistema, $S$, em duas partes: $S_{1}$ para a parte da mola e $S_{2}$ para parte do amortecedor e chamando de $S_{0}$ é o comprimento da mola 
quando seu potencial é mínimo, de acordo com a Eq. (1.6) para a mola, podemos escrever:

$$
-F=G\left(S_{1}-S_{0}\right) \Rightarrow G=-\frac{F}{\left(S_{1}-S_{0}\right)}
$$

assim como, conforme a Eq. (1.3)

$$
\eta=-\frac{F}{d S_{2} / d t}
$$

onde $F$ é a força aplicada sobre o sistema. Então, derivando no tempo o comprimento total do sistema, $S$, e utilizando as Eqs. (1.7) e (1.8), temos:

$$
\frac{d S}{d t}=\frac{d}{d t}\left(S_{1}+S_{2}\right)=-\left[\frac{1}{G} \frac{d F}{d t}+\frac{F}{\eta}\right]
$$

que pode ser reescrita como:

$$
F+\frac{\eta}{G} \frac{d F}{d t}=-\eta \frac{d S}{d t}
$$

De uma forma geral, podemos descrever o comportamento viscoelástico de um material polimérico, substituindo $F$ pela tensão $\sigma$, e $d S / d t$ pela taxa de deformação, $\dot{\lambda}$, onde $\lambda$ possui uma componente elástica e outra viscosa, $\lambda=\lambda_{E l}+\lambda_{V i s}$. Com isso a Eq. (1.10) fica:

$$
\sigma+\tau \dot{\sigma}=G \tau \dot{\lambda}
$$

onde

$$
\tau=\frac{\eta}{G}
$$

A Eq. (1.11) é conhecida como equação de Maxwell e $\tau$, dado pela Eq. (1.12), é o tempo de relaxação da viscoelasticidade do sistema. A Eq.(1.11) é capaz de descrever o comportamento viscoelástico de um sistema de forma geral, que opere entre os dois 
limites: fluido Newtoniano e sólido Hookiano. O tempo de relaxação desempenha um papel importante para determinar se no sistema predomina o comportamento tipo fluído Newtoniano ou sólido Hookiano [78].

Tendo em vista que o objetivo principal dessa seção é conceituar fisicamente os princípios que norteiam a técnica do OMTC, é interessante discutirmos como um material viscoelástico responde a uma tensão de cisalhamento oscilatório de pequena amplitude. Supondo uma tensão de cisalhamento oscilatória, a resposta à tensão também deve ser uma função oscilatória com uma determinada fase, então,

$$
\sigma=\sigma_{0} \exp \left(i\left(\omega t+\varphi_{\sigma}\right)\right)
$$

$\mathrm{e}$

$$
\lambda=\lambda_{0} \exp \left(i\left(\omega t+\varphi_{\lambda}\right)\right)
$$

onde $\varphi_{\sigma}$ e $\varphi_{\lambda}$ são as fases, $\sigma_{0}$ e $\lambda_{0}$ são as constantes de fase, da tensão e do cisalhamento gerado, respectivamente. A constante de fase $\lambda_{0}$ é a amplitude da tensão, que deve ser pequena o suficiente para que a condição de linearidade seja satisfeita [75]. Substituindo as Eqs. (1.13) e (1.14) na Eq. (1.11), teremos:

$$
\begin{aligned}
\sigma_{0}^{*} e^{i \omega t}+\tau \sigma_{0}^{*} i \omega e^{i \omega t} & =G \tau \lambda_{0}^{*} i \omega e^{i \omega t} \\
\frac{\sigma_{0}^{*}}{\lambda_{0}^{*}}(1+i \omega \tau) & =G i \omega \tau,
\end{aligned}
$$

onde, $\sigma_{0}^{*}=\sigma_{0} e^{i \varphi_{\sigma}}$ e $\lambda_{0}^{*}=\lambda_{0} e^{i \varphi_{\lambda}}$ e $\omega$ é a frequência de oscilação do campo magnético aplicado.

Podemos definir o módulo complexo de cisalhamento, $G^{*}$, que é outra maneira frequentemente usada para escrever a função da resposta viscoelástica, da seguinte forma:

$$
G^{*}=G^{\prime}+i G^{\prime \prime}=\frac{\sigma_{0}^{*}}{\lambda_{0}^{*}}
$$

onde, $G^{\prime}(\omega)$ é chamado de módulo de armazenamento, e está relacionada com a componente elástica do material, enquanto que, $G^{\prime \prime}(\omega)$ é chamado de módulo de perda 
e está relacionada com a componente viscosa do material. Portanto, combinando a Eq. (1.15) com a Eq. (1.16) temos:

$$
\begin{aligned}
G^{*} & =\frac{G i \omega \tau}{1+i \omega t}=\frac{G i \omega \tau}{1+i \omega t} \cdot \frac{1-i \omega t}{1-i \omega t} \\
G^{*} & =\frac{G \omega^{2} \tau^{2}}{1+\omega^{2} \tau^{2}}+i \frac{G \omega \tau}{1+\omega^{2} \tau^{2}} .
\end{aligned}
$$

Logo, pela Eq.(1.17) vemos que:

$$
G^{\prime}=\frac{G \omega^{2} \tau^{2}}{1+\omega^{2} \tau^{2}}
$$

$\mathrm{e}$

$$
G^{\prime \prime}=i \frac{G \omega \tau}{1+\omega^{2} \tau^{2}}
$$

A taxa de $G^{\prime \prime}$ por $G^{\prime}$ é chamada de tangente de perda [78],

$$
\tan \phi=\frac{G^{\prime \prime}}{G^{\prime}}
$$

São estas as definições básicas que norteiam conceitualmente a teoria envolvida na técnica do OMTC. Esta é uma técnica atual, utilizada para medidas que visam quantificar as propriedades elásticas e viscosas do esqueleto celular.

\subsection{Citometria óptica magnética de rotação}

Nesta técnica, $G^{\prime}(\omega)$ e $G^{\prime \prime}(\omega)$ são expressões mais complexas do que as apresentadas e possuem unidade de pressão ${ }^{2}$. Isto se deve ao fato das medidas dos módulos serem realizadas sobre microesferas aderidas na célula. Isto gera um fator

\footnotetext{
${ }^{2}$ No sistema internacional de unidades, Pascal (Pa) ou N/m².
} 
adicional na expressão do módulo de perda e de armazenamento, que depende da geometria da microesfera e da célula.

As microesferas utilizadas nesta técnica são ferromagnéticas de $4.5 \mu \mathrm{m}$ de diâmetro recobertas com um peptídeo sintético contendo uma sequência adesiva de três aminoácidos - arginine-glycine-aspartic acid (RGD), que são colocadas nas células e se aderem fortemente ao citoesqueleto por meio receptores (integrinas) na sua superfície [27,42]. A sequência RGD é comum a várias proteínas da matriz extracelular e é reconhecida pelas células por meio dos receptores. Estes, além de iniciarem uma sinalização bioquímica, também apresentam uma ligação física ao citoesqueleto de actina.

Inicialmente as microesferas são magnetizadas horizontalmente por um sistema de magnetização (EOL - Eletronics Optics Lasers for Biological and Medical Research) controlado por computador, para em seguida realizar as medidas, impondo um campo magnético vertical homogêneo, externamente, que varia senoidalmente no tempo. A aplicação deste campo gera um torque que causa a rotação das microesferas no sentido de se alinharem ao campo, conforme a Figura 5. Esta rotação é impedida, contudo, pelas forças mecânicas que se desenvolvem dentro das células, com a rotação das esferas. Esse equipamento se anexa à plataforma de um microscópio invertido (Leica DMI4000 B) com uma câmera de vídeo com dispositivo de carga acoplado (CCD), que transmite as imagens e é controlada por um computador com o auxilio de placas de vídeo e dados (National Instruments PCI-6251) e por um software desenvolvido pelo laboratório na linguagem computacional $\mathrm{C}++$.

O torque gerado nas microesferas, devido ao campo magnético externo, desloca lateralmente as esferas durante a sua rotação em resposta ao torque oscilatório. Este deslocamento é detectado pela câmera CCD. O movimento forçado das microesferas é modulado através das propriedades elásticas e viscosas do esqueleto celular. Com isto é possível medir o módulo complexo de cisalhamento, como uma função da frequência devido ao campo magnético oscilatório aplicado, e o deslocamento resultante da microesfera, da seguinte forma [27,79]:

$$
G^{*}(\omega)=G^{\prime}(\omega)+i G^{\prime \prime}(\omega)=\frac{T^{*}(\omega)}{d^{*}(\omega)}
$$


onde $T^{*}(\omega)$ é a Transformada de Fourier do torque aplicado e $d^{*}(\omega)$ é o deslocamento resultante. Esta equação é em essência, igual a Eq.(1.6), porém aqui temos a aplicação da Transformada de Fourier no torque e no deslocamento. Isto é necessário, pois, para obtermos $G^{*}$ para uma determinada frequência $\omega$, tanto o torque quanto o deslocamento também devem ser dados em função da frequência. No entanto, nesta técnica, essas grandezas são medidas ao longo do tempo, por isso a necessidade de se calcular a Transformada de Fourier.
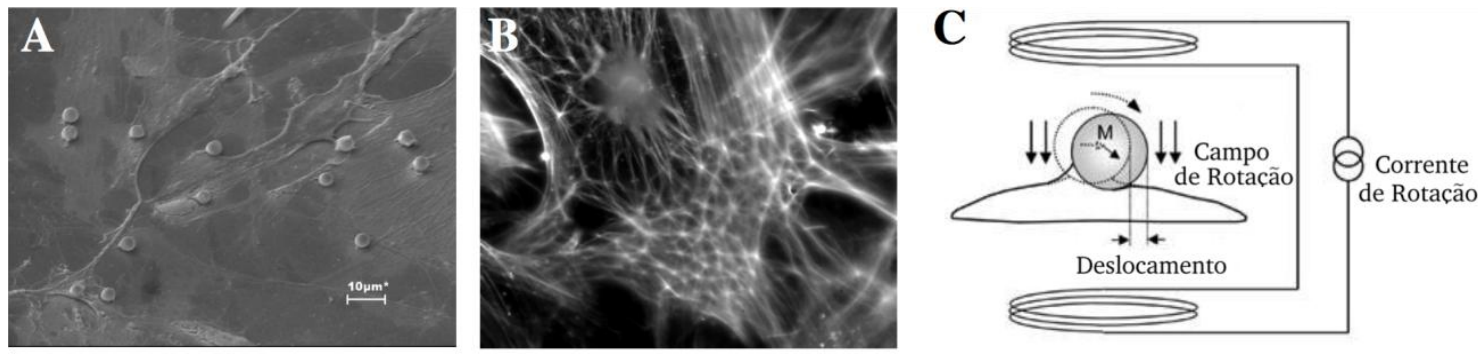

Figura 5: Esquema da técnica do OMTC. A: esferas ferromagnéticas ligadas ao citoesqueleto, imagem obtida por Microscopia Eletrônica de Varredura (MEV). B: imagem de fluorescência onde a esfera ferromagnética fica fortemente ligada no citoesqueleto (célula fixada com faloidina). C: o campo magnético introduz um torque que leva a esfera a girar e se deslocar. $\mathrm{M}$ denota a direção do momento magnético da esfera (imagem adaptada de [27]).

A técnica de OMTC pode ser utilizada para explorar as propriedades dinâmicas do esqueleto celular ao longo de um amplo intervalo de frequência, de 0.1 a $1 \mathrm{kHZ}$, assim como, pode ser aplicada a uma grande variedade de células, incluindo células do músculo liso, células endoteliais e epiteliais [27-29,79]. Recentemente, Dinardo e colaboradores utilizando a técnica do OMTC mostraram que CVML porcinas provenientes de um único animal, ou seja, geneticamente iguais, podem ter propriedades mecânicas diferentes, tanto se forem coletadas de partes diferentes do corpo, por exemplo, das artérias: femoral, aorta, mamária, renal, carótida e coronária [41], quanto se as mesmas forem cultivadas in vitro por um tempo maior ou menor [43]. 


\subsection{Caracterização mecânica de CVML via técnica de OMTC}

Nesta subseção mostraremos os resultados sobre a rigidez das CVML, realizadas pela pesquisadora Carla Dinardo et al., em 2013, nos estudos sobre propriedades mecânicas de CVML [41]. Portanto, descrevê-lo-emos aqui para podermos relacioná-los com os resultados da análise das imagens realizadas em nosso trabalho.

\subsubsection{Metodologia utilizada}

Esferas ferromagnéticas de $4.5 \mu \mathrm{m}$ foram recobertas com um peptídeo sintético contendo uma sequência de ácido arginine-glycine-aspartic (RGD) que se acoplam fortemente a receptores de integrina da célula. Estas esferas são depositadas no meio celular e decantam sobre as células que estão em placas (96 poços) previamente revestidas com $3 \%$ de gelatina porcina a uma concentração de 1 x $10^{4}$ células por poço. Depois de 12 horas as CVML foram privadas de soro por 24 horas e, então, as microesferas ferromagnéticas foram adicionadas às células a uma concentração de $10 \mu \mathrm{g}$ por poço para, então, iniciarem-se as medidas mecânicas [42,43].

As esferas foram primeiramente magnetizadas horizontalmente para, em seguida, ser aplicado um campo magnético oscilatório vertical de $0.75 \mathrm{~Hz}$ de frequência. O deslocamento das microesferas são opticamente registrados por uma câmera CCD acoplada a um microscópio invertido. O módulo complexo de cisalhamento foi calculado via Eq. (1.21). O valor do $\left|G^{*}\right|$ a uma frequência de $0.75 \mathrm{~Hz}$ foi denominado de G. As CVML de diferentes leitos arteriais foram comparadas em termos do valor médio de $\mathrm{G}$.

As CVML foram extraídas de porcos fêmeas, conforme metodologia descrita no Anexo I. Por mais que tenha-se utilizado um padrão para escolha dos porcos, existe uma certa aleatoriedade entre os animais utilizados nos experimentos. Devido a isto, calculou-se o que foi chamado de $Z G$ das CVML, a partir do resultado de $\mathrm{G}$ de todos os poços analisados (individualmente para cada animal) [41]. Este $Z G$ foi obtido pelo método conhecido como standard score. Para isto, calculou-se o valor médio de G de 
todos os experimentos realizados nos leitos arteriais e dividiu-se este valor pelo desvio padrão de $\mathrm{G}$ para todas as artérias. Isto é comumente utilizado para se comparar os dados de um tipo de amostra com o desvio padrão normal, ou seja, uma distribuição normal com valor esperado igual a zero e variância igual a um. Com isto, valores de $Z G$ acima do valor médio de G, possuem valor positivo. Enquanto que, $Z G$ abaixo da média, possuem valor negativo.

Foram realizadas as seguintes quantidades de experimentos nos respectivos leitos arteriais: 51 - mamária; 49 - carótida; 38 - renal e 33 para cada um dos seguintes leitos, coronária, aorta abdominal, aorta torácica e femoral [41]. Foram adotadas algumas condições para validação dos experimentos, que são: as CVML deveriam estar confluentes e dispostas em uma monocamada; deveriam ser identificadas no mínimo 150 microesferas pelo computador; as CVML deveriam apresentar uma morfologia regular, antes e depois do experimento.

\subsubsection{Resultados obtidos}

A rigidez, $G$, das CVML mostrou ser diferente com relação ao leito arterial. Para cada leito foi calculado o valor médio da rigidez, $Z G$, e encontrou-se uma diferença significativa entre a rigidez dos leitos $(p<0.001)$. Para melhor análise destes resultados, foi construído um gráfico de $Z G$ para cada leito arterial, conforme Figura 6. Nesta figura, as CVML foram distribuídas conforme sua distância ao coração, do mais afastado para o mais próximo. Vemos uma tendência de diminuição de $Z G$ quanto menor for sua distância ao coração, onde, na femoral temos o valor máximo de $Z G$, enquanto que na aorta torácica o mínimo. Logo, vemos que as CVML tendem a ser mais moles quanto mais próximas ao coração.

Nota-se que o resultado para as células da coronária está desvinculado dos demais leitos arteriais, Figura 6. Esta distinção foi feita, pois, a coronária tem um comportamento diferente dos demais leitos na árvore arterial. Este recebe irrigação sanguínea durante a diástole, que é um período de relaxamento onde o coração recebe o sangue das veias, enquanto que todos os demais leitos são irrigados durante a sístole, que é quando o coração contrai e ejeta sangue nas artérias. 
Quando estes dados mecânicos foram comparados com dados anatômicos das células, observou-se que as CVML de artérias com menores quantidades de matriz extra celular (femoral e renal) são mais rígidas quando comparadas com as CVML da aorta torácica, que apresenta maior quantidade de matriz extra celular [41]. Além destes resultados, Carla Dinardo et al., concluíram que as CVML são heterogêneas com relação à viscoelasticidade e a quantidade de proteínas do citoesqueleto ao longo da árvore arterial. Suas propriedades mecânicas podem ser influenciadas pelas características da matriz extra celular assim como, podem ser moduladas pelo estresse circunferencial cíclico aplicado ao vaso pelo fluxo sanguíneo [41].

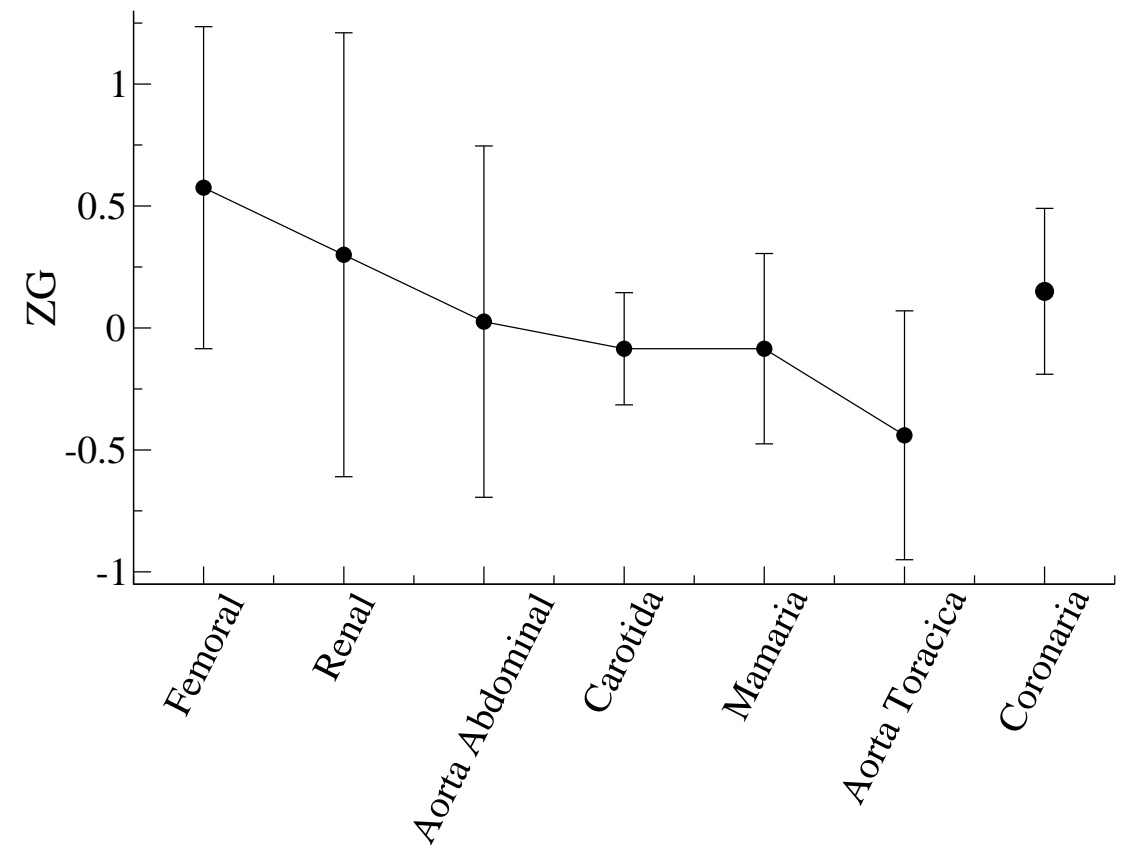

Figura 6: Comportamento da rigidez média $Z G$ das CVML. As artérias estão dispostas em ordem decrescente da distância ao coração, sendo elas: Femoral, Renal, Aorta Abdominal, Carótida, Mamária e Aorta Torácica (imagem adaptada de [41]).

Para explicar este resultado, criamos uma plataforma de análise de imagens de células para podermos correlacionar suas propriedades estruturais e morfológicas com as mecânicas. Na próxima sessão, abordaremos os conceitos básicos sobre imagens, como são feitos os tratamentos de análise e seus fundamentos, que constitui o maior foco deste trabalho. 


\subsection{Análise de imagens}

Avanços recentes na área de microscopia de alta resolução têm proporcionado novas oportunidades de análises de processos biológicos, antes inacessíveis. Isto vem popularizando o processamento e análise de imagens digitais, que agregam riqueza de informação para o entendimento de processos físicos e biológicos, como por exemplo, alteração morfológica e efeito de drogas em células e tecidos, variação de conformação estrutural de células sobre estresse mecânico, entre outras. Assim, torna-se possível a criação de novas ferramentas de pesquisa que acompanhem o avanço na área de microscopia e sejam capazes de lidar com as informações contidas nas imagens, provendo dados estatísticos que possam ser confrontados com técnicas experimentais [46].

Nesse contexto, uma imagem monocromática pode ser definida como uma função bidimensional, $f(x, y)$, onde $x$ e $y$ são as coordenadas espaciais, e a amplitude da função $f$ em qualquer par de coordenadas $(x, y)$ é chamada de intensidade ou nível de cinza da imagem naquele ponto [80]. Imagens coloridas no formato RGB (do inglês red $(\mathrm{R})$, green $(\mathrm{G})$, e blue $(\mathrm{B}))$ são constituídas de três imagens monocromáticas individuais, que são, vermelho, verde e azul. Formatos popularmente utilizados para guardar imagens em câmeras digitais é o JPEG e o PNG. Estes tipos de imagens são comprimidas por funções do tipo de Fourier e ocupam um espaço menor de armazenamento. Imagens no formato TIFF, BMP e PNM, são significativamente maiores do que as anteriores, em termos de espaço de armazenamento, e são uma boa opção de formato para serem processadas futuramente. Por fim, existem as imagens vetorizadas do tipo, PDF e PS, que são imagens geradas por funções matemáticas que descrevem as formas geométricas contidas na imagem.

Destes vários tipos de imagens existentes, as tipicamente trabalhadas são imagens em escala de cinza e imagens RGB [80]. Geralmente o processamento das imagens é feito em escala de cinza ou nas monocamadas individuais de uma imagem RGB, tendo em vista que, geralmente cada camada armazena um determinado tipo de informação e então, são processadas individualmente. Estas imagens são ditas imagens digitais, e são compostas de um número finito de elementos, cada qual com sua posição e valor específicos. Estes elementos são definidos como pixels da imagem [80]. 
O processamento de imagem feito de forma computadorizada é geralmente desenvolvido em softwares específicos e linguagens computacionais que oferecem as ferramentas necessárias para as análises. Dos vários softwares existentes, podemos citar dois que são comumente utilizados no meio acadêmico, o MATLAB e o ImageJ. Ambos são softwares de alta performance para técnicas computacionais que integram, basicamente, visualização e programação $[49,80]$. Em nosso trabalho, optamos por usar o MATLAB, devido à disponibilidade, qualidade e praticidade, pois, este software possui uma vasta biblioteca de análise de imagens e uma ampla bibliografia de trabalhos que o utilizam para este fim.

No MATLAB, como dito anteriormente, as imagens são interpretadas como matrizes e as operações são realizadas nos componentes dessa matriz, conforme Figura 7. Podemos dividir os processos computacionais em três etapas: primitiva, intermediária e avançada. Os processos primitivos envolvem: redução do ruído, realce do contraste e melhora da nitidez da imagem [80]. Este processamento é importante, pois as imagens obtidas por câmeras digitais, como as câmeras CCD, estão sujeitas a várias imperfeições na sua configuração de aquisição [81].

O processamento intermediário tipicamente envolve: segmentação, que é particionar a imagem em regiões ou objetos, descrever, classificar e reconhecer esses objetos. Este processamento é caracterizado pelo fato de que o resultado do processamento da imagem não é uma nova imagem, mas sim parâmetros extraídos da imagem, tais como: bordas, contornos, área, identificação de objetos individuais, entre outros [80]. Por fim, processamentos avançados consistem de uma análise de imagem no intuito de dar sentido aos dados extraídos, desenvolver funções para lidar com os dados e construir gráficos ou esquemas para interpretá-los.

Em nosso trabalho incorporamos as três etapas citadas para o processamento de imagens digitais no formato TIFF, onde, as coordenadas espaciais $x$ e $y$, e o valor da amplitude da função $f$, são valores inteiros, ou seja, quantidades discretas. 

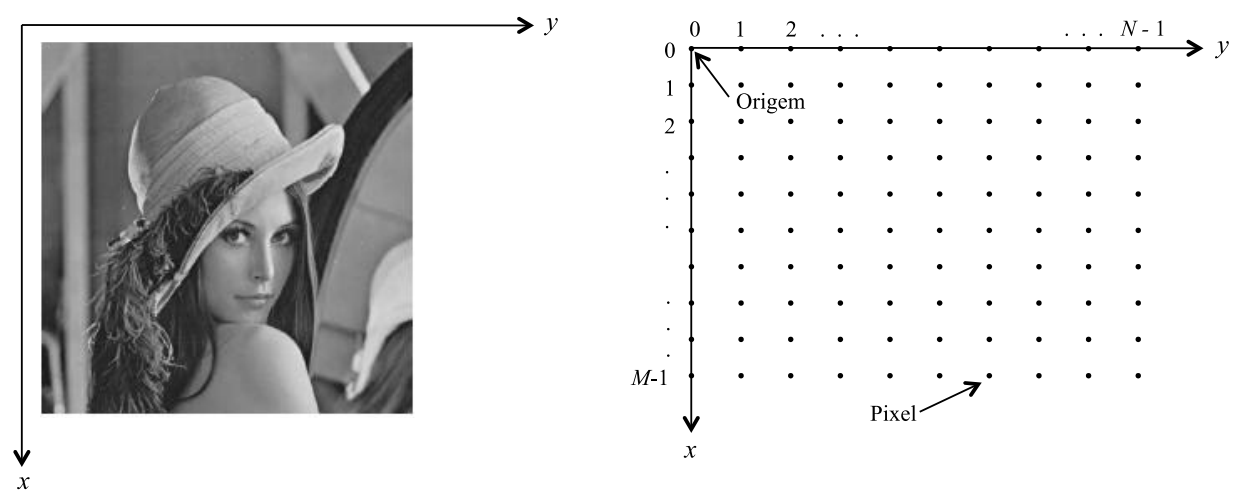

Figura 7: Esquema representativo de uma imagem, vista por um computador. À esquerda temos uma imagem em escala de cinza, que pode ser usada como entrada para algum tipo de processamento computacional. À direita temos um esquema de uma matriz $M$ por $N$, equivalente à imagem da esquerda, onde cada ponto da matriz representa um pixel da imagem.

\subsubsection{Microscopia de fluorescência}

Esta técnica de microscopia confocal oferece vantagens significativas com relação a microscópios fluorescentes convencionais [82]. Isto é devido à exclusão da maior parte da luz vinda da amostra que não está no plano focal do microscópio, gerando assim, um maior contraste na imagem [83]. A microscopia confocal é uma recente combinação de tecnologia de fluorescência e de exposição de imagem ponto a ponto, que tem proporcionado novas oportunidades para análises de estruturas celulares [82,84]. Um microscópio confocal cria imagens nítidas de estruturas que não seriam definidas, caso analisadas em um microscópio de fluorescência convencional, conforme Figura $8[83,85]$. 

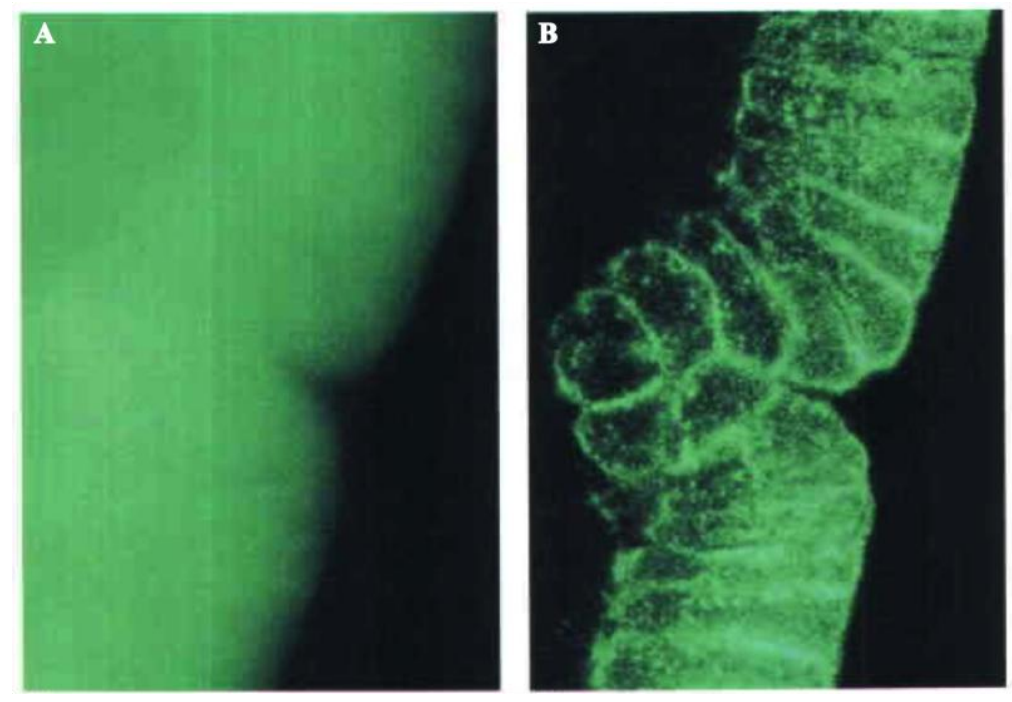

Figura 8: Comparação entre uma imagem obtida por microscopia de fluorescência convencional (A) e por confocal (B). Ambas as imagens evidenciam filamentos de actina de um embrião de Drosófila. A imagem $\mathbf{A}$, fica ofuscada devido à presença de estruturas fluorescentes acima e abaixo do plano focal. Enquanto que a imagem $\mathbf{B}$, as estruturas fluorescentes fora de foco são removidas, resultando em uma imagem mais nítida (imagem adaptada de [86]).

A aplicação biológica mais comum da microscopia confocal está na detecção de fluoróforos excitados, que nada mais são do que corantes aplicados na amostra, por instrumentos úteis na captação de imagem por refletância. No modo fluorescente, o microscópio confocal é capaz de resoluções de $0.2 \mu \mathrm{m}$ no plano focal (eixos laterais $x \mathrm{e}$ y) e $0.8 \mu \mathrm{m}$ na direção axial $(z)$ [84].

Para um melhor entendimento do microscópio confocal, construímos um esquema de um par de lentes que centraliza a luz do foco de uma lente para o foco da outra, como ilustrado na Figura 9. O feixe em vermelho representa luz fora do plano foco das lentes e, portanto, é barrado na parede e não passa pelo orifício do confocal para formar a imagem. 


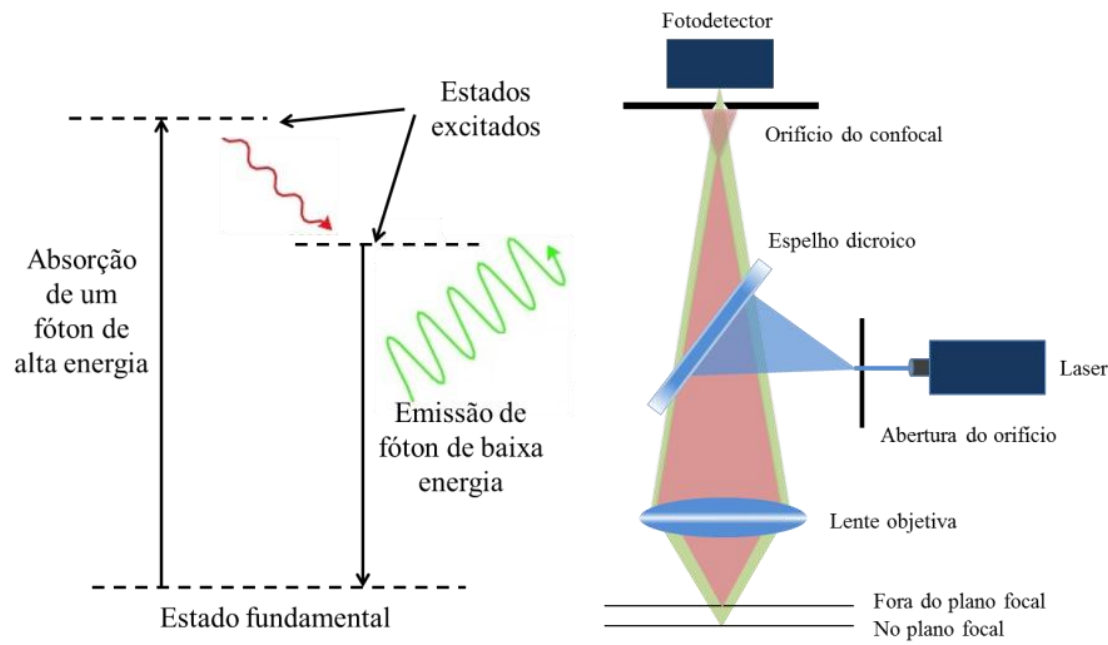

Figura 9: Esquema do funcionamento da fluorescência por um microscópio confocal. Na imagem da esquerda, as linhas horizontais indicam um quantum de nível de energia da molécula. Um corante fluorescente da molécula é elevado a um estado de energia excitado por absorção de um fóton de energia. Um pouco de energia é perdida para outras moléculas e decai para um estado de energia inferior. O restante da energia é perdida por emissão de luz com menor energia do que a absorvida. Na imagem da direita, temos a rejeição da luz que não incide no plano focal. Toda luz vinda do ponto focal, que atinge a tela, passa pelo orifício. Enquanto que, os feixes de luz que não estão no ponto focal são barrados.

Uma grande variedade de fluoróforos tem sido desenvolvida para se estudar a biologia celular. As moléculas fluoróforas percorrem um caminho dentro da célula e se fixam às estruturas intracelulares de interesse, tais como, fibras de actina, microtúbulos e núcleo [83]. A adesão de fluoróforos ou outros marcadores úteis em proteínas é geralmente acompanhado de uma modificação química in vitro [87]. Uma marcação química seletiva é geralmente obtida por um sítio de ligação específica entre a proteína de interesse e o componente fluorescente [88].

As imagens celulares geradas por esta técnica contêm uma riqueza de objetos e padrões que podem transmitir informações fundamentais sobre o mecanismo do citoesqueleto celular. Portanto, uma análise de imagem bem sucedida pode prover meios de quantificar estes objetos, seus padrões e, assim, responder importantes perguntas de interesse biológico. As imagens utilizadas neste trabalho foram obtidas pela técnica de microscopia confocal onde foram evidenciadas as fibras de actina da célula. 


\subsubsection{Processos de identificação de bordas em uma imagem}

Existem vários trabalhos na literatura mostrando a importância que a orientação das fibras de actina desempenham nas funções celulares $[50,51,55,61,89]$. São duas as técnicas mais utilizadas por pesquisadores dessa área para este fim, a identificação de bordas pelo operador de Sobel e a Transformada de Fourier (FFT do inglês Fast Fourier Transform) [50,60,90-93].

Uma boa aplicação da FFT para análise de imagem de células foi a utilizada por Javier Adur et al., no seu trabalho de 2012, onde basicamente se analisou o tumor de ovário de células epiteliais humanas pela técnica de Microscopia de Segundo Harmônico (MSH) e FFT para análise das imagens [55]. Com a utilização da FFT, foi possível caracterizar a anisotropia das fibras de colágeno destas células, conforme Figura 10. Nesta figura, as áreas na imagem das células normal e maligna, as fibras de colágeno e o epitélio, da imagem $\mathbf{A}$, foram selecionadas manualmente.

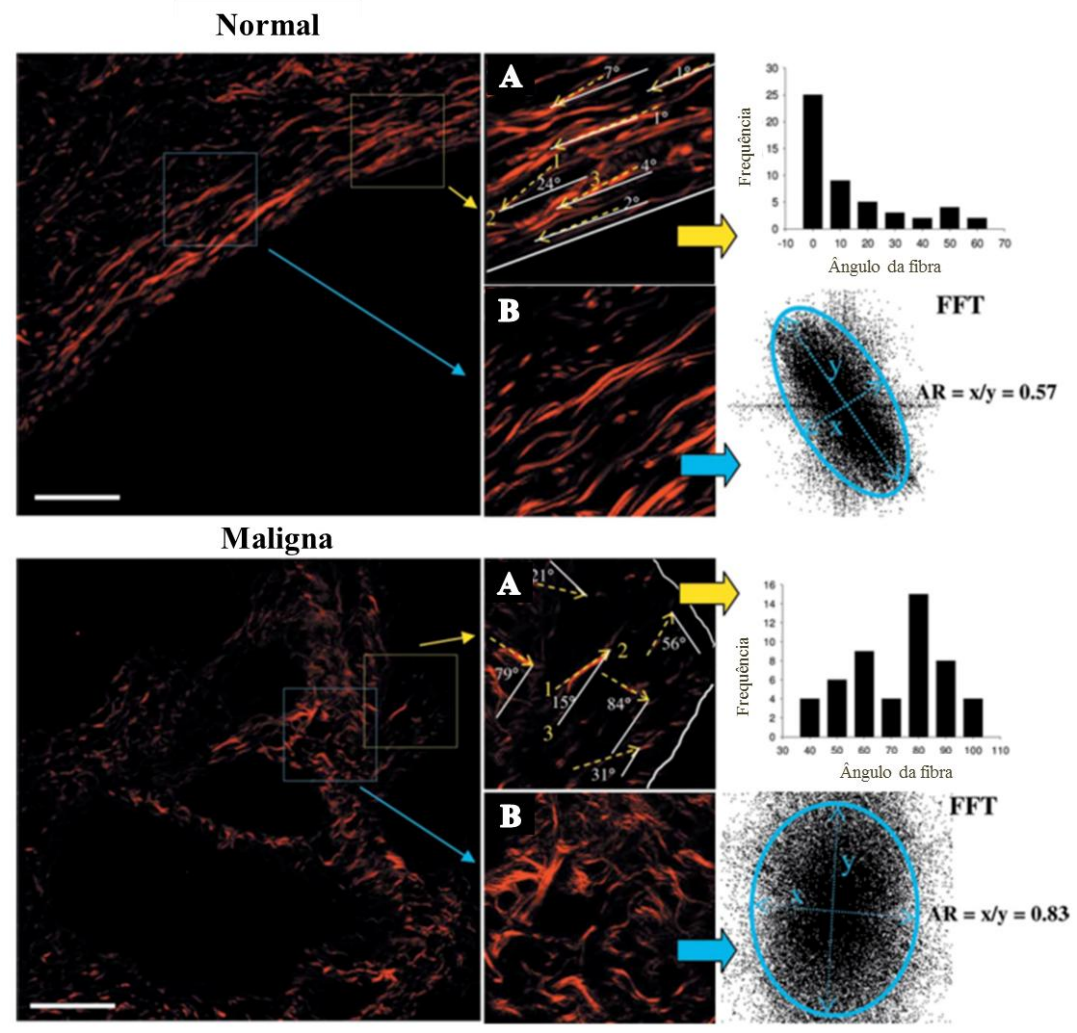

Figura 10: Aplicação da FFT em imagens de tecidos normais e malignos obtidos por MSH. Em A, foi medido o ângulo das fibras de colágeno (linhas amarelas) relativo ao alinhamento do epitélio (linha branca). O histograma ao lado representa a distribuição total das fibras. Em B, região representativa para o cálculo da FFT e o correspondente ajuste da elipse (azul) para o cálculo da anisotropia. $x$ : menor eixo, $y$ : maior eixo, AR: relação de aspecto. Barra de escala $=20 \mu \mathrm{m}$ (imagem adaptada de [55]). 
Os pontos gerados pelo cálculo da FFT referente à Figura 10(B) são ajustados pela elipse em azul de forma manual, onde, o valor de AR varia de 0 até 1 e quanto menor o valor de AR mais organizadas estão as fibras. Com a análise feita pelos pesquisadores deste trabalho foi possível observar alterações no colágeno via MSH com progressão de tumor epitelial assim como, quantificar a orientação das fibras de colágeno com relação ao epitélio de forma a obter uma relação entre a alteração da orientação das fibras de colágeno com o progresso do tumor epitelial [55].

Entretanto, a técnica da FFT não é sensível o suficiente para cálculos da orientação preferencial de fibras, ou o ângulo por pixel da imagem, segundo trabalho publicado por Kmeny et al., em 2011. Neste trabalho, os pesquisadores também mostraram que o operador de Sobel é mais sensível que a FFT para este tipo de análise.

O operador de Sobel é basicamente um identificador de bordas em uma imagem. As bordas de uma imagem são uma de suas características mais básicas, de forma que sua detecção é uma das investigações mais fundamentais em processamentos de imagem [94]. Tecnicamente, o operador de Sobel é um operador diferencial discreto que calcula a aproximação do gradiente da intensidade da imagem [95]. Em cada ponto da imagem, o resultado que o Sobel fornece corresponde ao vetor gradiente naquele ponto.

Basicamente, uma borda é determinada quando a derivada de primeira ordem tem um valor máximo naquele local [91]. Para uma função contínua, $f(x, y)$, na posição $(x, y)$, seu gradiente pode ser expresso pelo vetor:

$$
\nabla f=\left[H_{x}, H_{y}\right]=\left[\frac{\partial f}{\partial x}, \frac{\partial f}{\partial y}\right] .
$$

O gradiente aponta na direção da mais rápida mudança na intensidade. A direção do gradiente é dada por:

$$
\theta=\arctan \left(\frac{H_{y}}{H_{x}}\right)
$$

A intensidade da borda é dada pela magnitude do gradiente 


$$
\|\nabla f\|=\sqrt{H_{x}^{2}+H_{y}^{2}} .
$$

O cálculo do gradiente de uma imagem digital é baseada nas derivadas parciais $H_{x}$ e $H_{y}$ em cada pixel da imagem. Uma vez que as imagens digitais possuem apenas pontos discretos. O operador Sobel utiliza duas matrizes quadradas que percorrem a imagem nas direções $x$ e $y$, para calcular um valor aproximado ao das derivadas da Eq. (1.22) $[90,93,95]$. A dimensão das matrizes utilizadas determina a precisão do gradiente. Usualmente, utiliza-se a maior precisão possível, ou seja, menor dimensão da matriz, que no caso do operador Sobel é uma matriz $3 \times 3$.

Em um trabalho de 2003, Yoshigi et al., utilizaram o operador de Sobel para identificação das fibras de actina evidenciados em uma imagem obtida por microscopia de fluorescência. Neste trabalho os pesquisadores procuraram quantificar o alinhamento de CVML da imagem de um tecido, calculando o alinhamento das fibras de actina das células. A hipótese era de que, quantificando o alinhamento das fibras de actina eles poderiam entender como as células estão alinhadas [93]. A Figura 11, mostra um dos resultados obtidos por estes pesquisadores, utilizando o operador de Sobel. Esta figura ilustra a capacidade do operador em quantificar o alinhamento das fibras de actina de CVML submetidas a um estresse mecânico.

Analisando a Figura 11, vemos que, quando as células não estão submetidas a nenhum estiramento, os filamentos não apresentam nenhuma orientação preferencial, porém, quando se aplica o estiramento na direção horizontal por 5 e 10h, as fibras começam a se alinhar perpendicularmente ao estiramento, de forma a contrabalancear esta força [93].

Portanto, optamos por utilizar o operador de Sobel para realizar nossas análises, tanto por ser mais sensível na identificação das bordas em uma imagem, como por fornecer o valor do ângulo por pixel, gerando assim uma quantidade maior de dados para análise estatística [50]. Em nossa metodologia, identificamos as fibras de actina e calculamos de sua orientação, seguindo o procedimento desenvolvido por Yoshigi et al. 

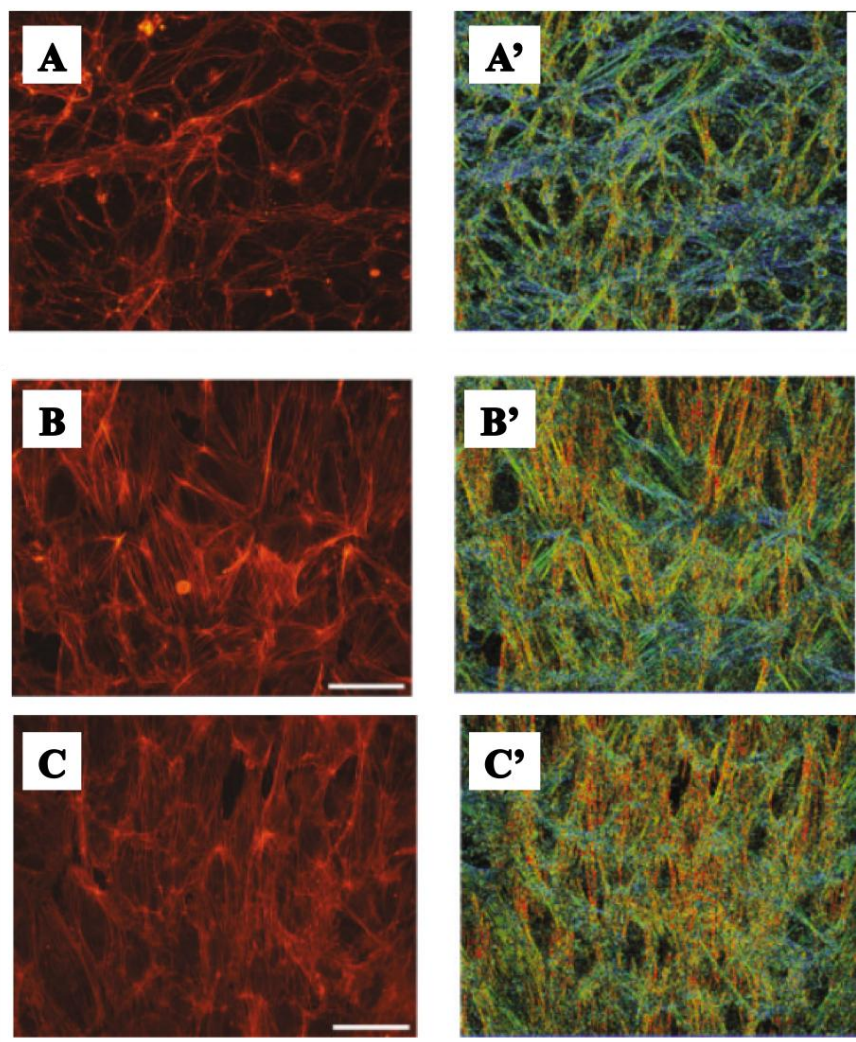
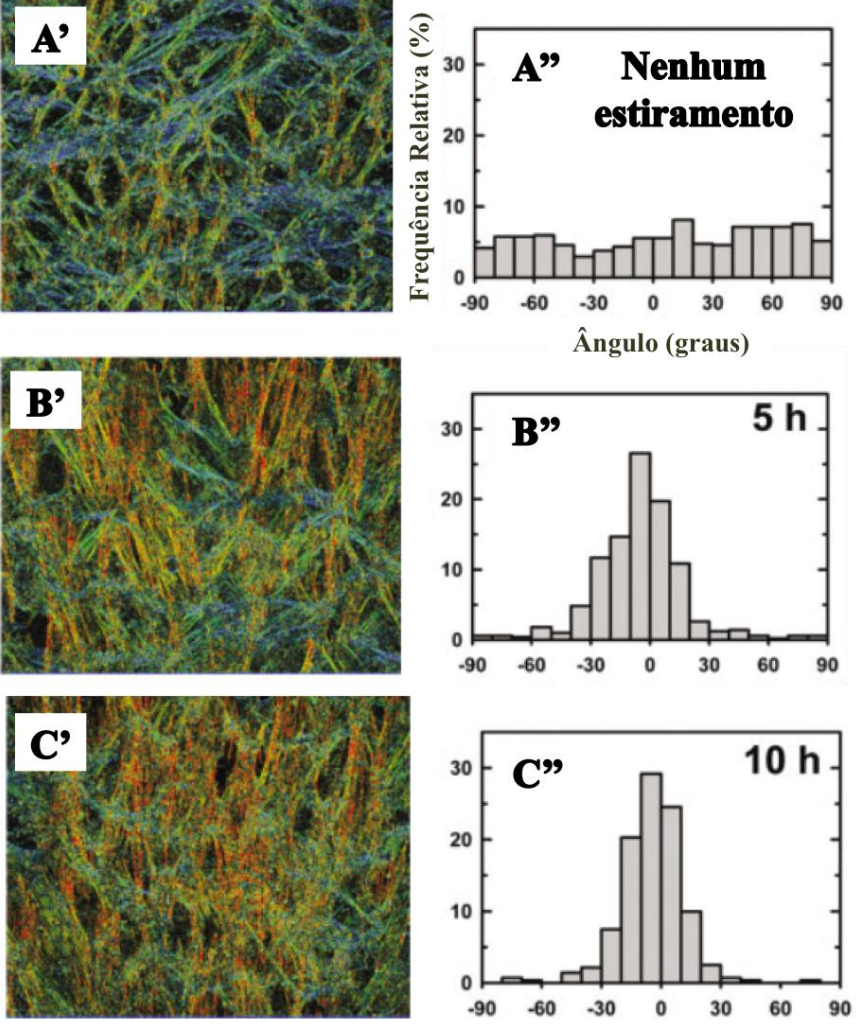

Figura 11: Orientação do citoesqueleto sobre indução de estiramento em células confluentes. A-C: transição do alinhamento do citoesqueleto sobre estiramento com relação ao tempo. A'-C': colorização da orientação das fibras correspondente a cada imagem. Fibras vermelhas estão orientadas perpendicularmente à direção do estiramento, e as azuis paralelamente. A',C': histograma da orientação das fibras calculada para 30 imagens. Barra de escala $=50 \mu \mathrm{m}$ (imagem adaptada de [93]).

\subsubsection{Dimensão fractal}

Uma segunda característica importante analisada em nosso processamento foi com relação à morfologia celular, ou seja, analisamos a Dimensão fractal, $D_{f}$, das células. Recentemente, o estudo sobre geometrias fractais tem crescido em diversas áreas de conhecimento [50,54,57,96-101]. Objetos que possuem geometria fractal podem ser encontrados na natureza ou gerados usando procedimentos matemáticos. Apesar das ideias relacionadas a objetos fractais terem tido sua origem com Leonardo da Vinci, o termo "fractal" foi inicialmente proposto por Benoit Mandelbrot, quando este percebeu que, em alguma situações, é impossível descrever objetos da natureza usando apenas geometria Euclidiana, ou seja, em termos dimensões inteiras. Mandelbrot 
propôs que, geometrias fractais poderiam melhor descrever objetos reais, tais como: árvores, relâmpagos, costas marinhas, entre outros [102].

Os tipo de dimensão mais compreensíveis e utilizadas para descrição de objetos, são: a dimensão Euclidiana e a dimensão topológica. No espaço Euclidiano a dimensão de qualquer objeto ou conjunto de objeto é descrito por números inteiros, 0 para um ponto, 1 para uma linha reta, 2 para uma superfície plana e 3 para um volume ou figura tridimensional [54]. Basicamente, a dimensão Euclidiana é o número de coordenadas necessárias para especificar um objeto [102].

A dimensão topológica está atrelada ao objeto e permanece a mesma sobre qualquer transformação que o objeto possa sofrer sem perder suas características essenciais. Uma linha reta, por exemplo, pode ser transformada em uma curva suave ou rugosa, de forma que a topologia de cada uma seja equivalente [102]. Todavia, quando uma linha reta é transformada em uma curva, a dimensão Euclidiana passa de 1 pra 2. Na Figura 12, podemos ver alguns exemplos que ilustram a diferença entre a dimensão Euclidiana, $D_{E}$, e a dimensão topológica, $D_{T}$, de um objeto.

Os objetos fractais possuem forma complexa que não podem ser medidas apenas pela dimensão topológica. Estes tipo de estruturas podem ser melhor descritas por números não-inteiros, com valores que variam entre a dimensão Euclidiana e a topológica [54]. Estes valores não-inteiros são o que definem a $D_{f}$ de um objeto. De uma maneira geral, podemos definir um fractal como sendo um objeto auto-similar sobre vários graus de magnificação [102,103]. São objetos que apresentam simetria independente da escala, onde cada pequena parte do objeto representa a estrutura como um todo. A $D_{f}$ tem sido utilizada em diversos campos de pesquisa para se analisar, por exemplo, textura, segmentação, formato, crescimento de tumor, infecção de vírus, entre outros $[56,57]$. 


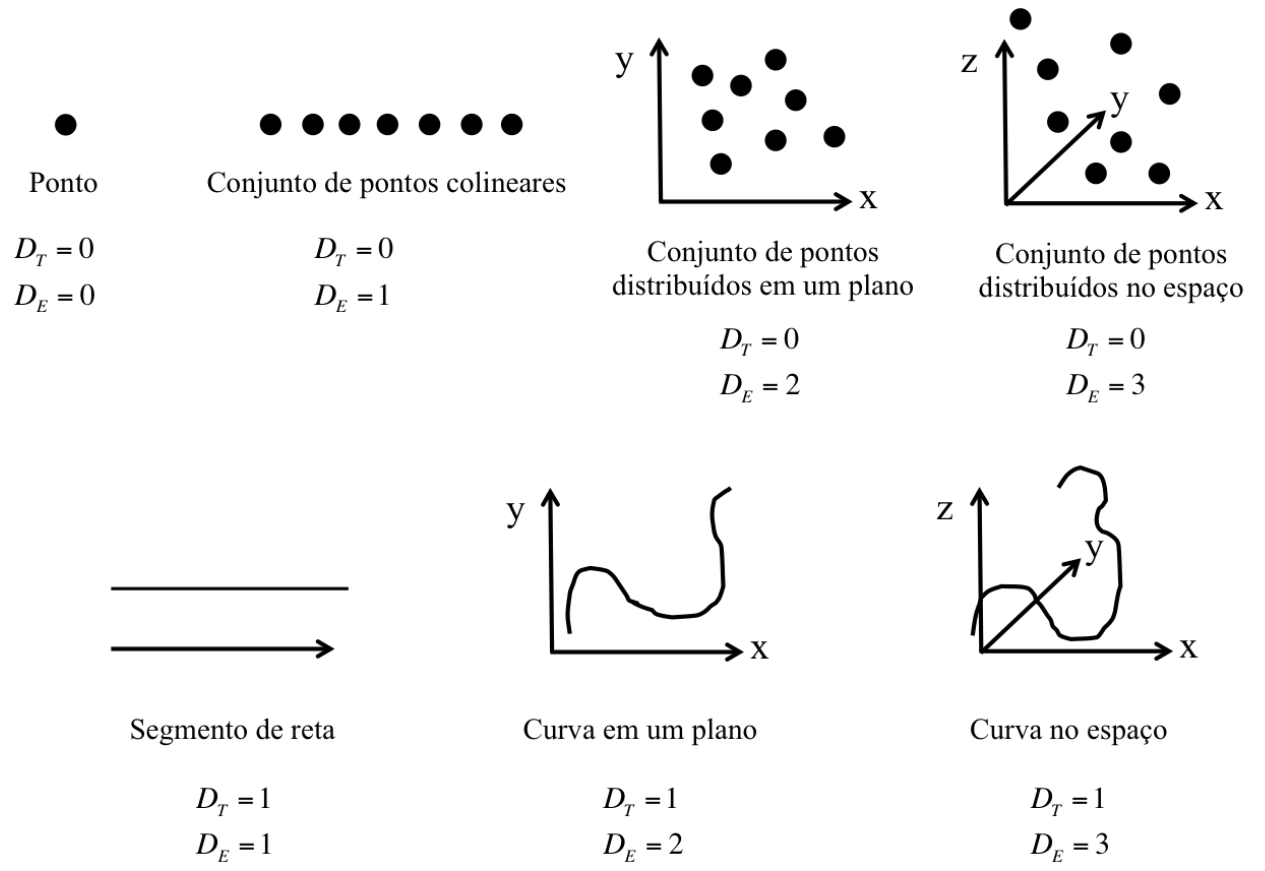

Figura 12: Dimensão Euclidiana e topológica para diversos tipos de objetos. Por clareza, na figura superior os pontos foram representados por círculos com raio maior do que zero.

Entretanto, existe outra categoria de fractais, conhecida como "fractais aleatórios". Estes tipos de fractais são estatisticamente auto-similares. Cada pequena parte destes fractais tem as mesmas propriedades estatísticas do todo [102]. Medir a dimensão desses objetos é um bom caminho para quantificar as propriedades estatísticas auto-similares dos fractais aleatórios. Devido à morfologia complexa e irregular da célula, ou do citoesqueleto, sua geometria e dimensão se enquadram nesta categoria de fractais. Se analisarmos a célula sobre diferentes magnificações, não encontraremos uma pequena parte que representa exatamente o todo, mas sim, pequenas partes que têm propriedades estatísticas similares ao todo.

Um método muito utilizado para estimar a $D_{f}$ desses objetos é o método de box counting [56,102]. Para se calcular a $D_{f}$ de um objeto por este método, cobre-se o objeto de interesse com "caixas" quadradas de lado L. O número de caixas necessárias para recobrir o objeto de interesse $N$, está relacionado com $L$ para o calculo da $D_{f}$. Se imaginarmos a situação de recobrir um plano de área unitária com caixas, verificaríamos que seriam necessárias $N=1 / L^{2}$ caixas de lado $L$, e uma dimensão Euclidiana maior ou igual a dois. De forma similar, para recobrir um sólido tridimensional seriam necessárias $N=1 / L^{3}$ de lado $L$, e uma dimensão Euclidiana 
maior ou igual a três. Notamos que em cada caso o expoente de $L$ é a medida da dimensão do objeto.

Podemos generalizar a expressão para o número de caixas necessária para recobrir um objeto com, $N=1 / L^{D_{f}}$, onde o expoente $D_{f}$ é a dimensão fractal do objeto [102]. Desta forma, podemos ter a seguinte equação geral:

$$
D_{f}=\frac{\log (N)}{\log (1 / L)}
$$

Uma alternativa mais refinada para o calculo de $D_{f}$ pode ser obtida quando variamos o tamanho dos quadrados que recobrem o objeto de interesse da imagem e criamos um gráfico do logaritmo da quantidade, $N$, de quadrados, necessários para recobrir o objeto, pelo logaritmo do inverso do comprimento do lado, $L$, do quadrado. A inclinação da curva que melhor ajusta os pontos deste gráfico representa a $D_{f}$ do objeto.

A última característica importante analisada em nossos processamentos foi à identificação e o comprimento das fibras de actina das células. Esta análise foi realizada com a motivação de posteriormente podermos correlacionar os dados do alinhamento das fibras e sua $D_{f}$ com sua distribuição de comprimentos. Outro fator importante que motivou a análise foi poder correlacionar com o modelo teórico de percolação, conforme será abordado na próxima seção.

\subsection{Modelo de Percolação}

Em termos gerais, a teoria da percolação lida com a geometria e a desordem de redes e materiais [104-106]. Seus conceitos são utilizados em várias aplicações nas teorias de sólidos desordenados e de transição vítrea [107]. Também podemos utilizar a teoria de percolação para tratar a conectividade de sistemas geometricamente complexos, assim como, para descrever sistemas físicos nos quais um fluído se propaga por um meio poroso de forma aleatória.

Uma das principais razões dessa teoria ser amplamente estudada vem do fato da sua interdisciplinaridade, uma vez que, pode ser aplicada a problemas e sistemas 
biológicos, sociais, geológicos e físicos. Os problemas envolvendo percolação podem ser desenvolvidos e testados utilizando métodos de mecânica estatística como, teoria de escala, transição de fase, ponto crítico, etc [107].

Para um melhor entendimento da teoria de percolação, imaginemos uma rede quadrada, grande o suficiente para que qualquer efeito das bordas possa ser negligenciado. Agora, certa fração dos sítios da rede são preenchidos com pontos, enquanto outros continuam vazios, conforme esquema da Figura 13(A). A ocupação desses sítios é aleatória com probabilidade $p$, onde essa probabilidade é completamente independente da ocupação ou não, do seu vizinho [107,108]. As regiões circuladas, na Figura 13(A), denotam um agregado, ou seja, um grupo de sítios vizinhos ocupados pelos pontos.

$\mathbf{A}$

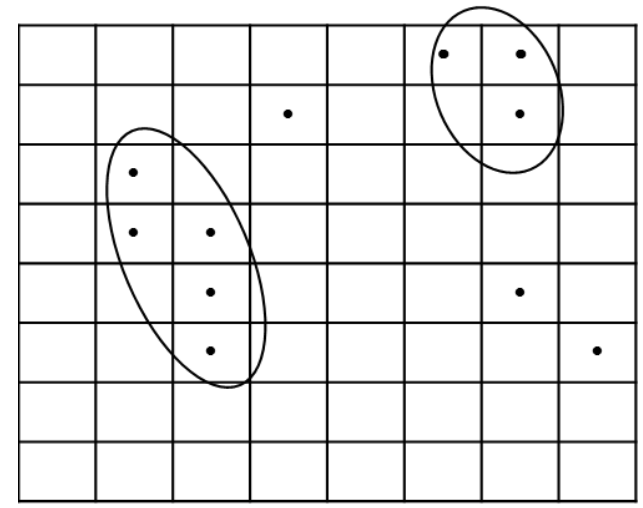

B

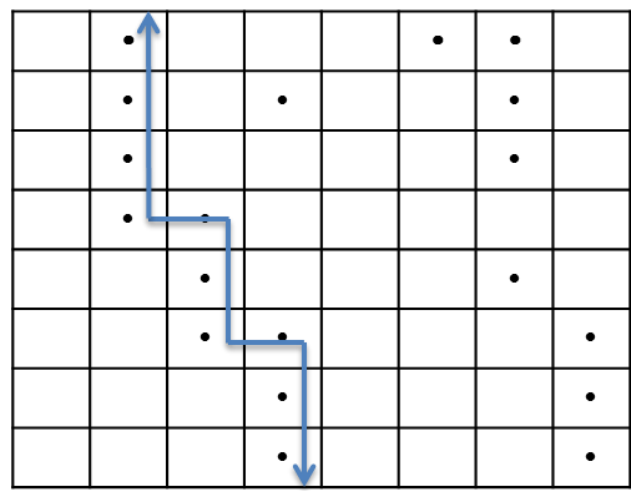

Figura 13: Esquema ilustrativo para definir percolação e seus agregados. A: rede quadrada, onde cada quadrado representa um sítio da rede. As regiões circuladas representam a formação de agregados pela ocupação de alguns sítios por pontos centrais de forma aleatória. B: rede percolada. $\mathrm{O}$ caminho em azul indica que existe um caminho, entre os agregados, do qual pode-se atravessar a rede de uma extremidade a outra.

Nesta figura, chamamos de primeiros vizinhos os sítios preenchidos que tem um lado em comum, já os sítios preenchidos que se tocam pelo vértice são chamados de próximos primeiros vizinhos e não formam um agregado. Conforme aumentamos a probabilidade, $p$, de ocupação da rede, a partir de valores pequenos, vemos que, existe um valor crítico, limiar de percolação $p_{c}$, em que o agregado passa a conectar a rede de uma extremidade a outra, quando isto ocorre dizemos que a rede está percolada $[105,109,110]$, conforme Figura 13(B). Podemos dizer que a teoria de percolação lida 
com as propriedades estatísticas e características morfológicas dos agregados formados na rede, ou seja, com o grupo de sítios vizinhos ocupados na rede [108].

Os pioneiros a estudarem o limiar de percolação em uma rede foram os pesquisadores Broadbent e Hammersley, em 1957, que introduziram um modelo de rede para o fluxo de um fluido por um meio aleatório estático, e mostraram rigorosamente que o fluido somente fluiria se a concentração do meio ativo fosse menor que um valor de limiar, ou seja, este meio deveria possuir poros ou caminhos nos quais fosse possível o fluxo do fluido [111]. Foram eles que introduziram a ideia de probabilidade de percolação, onde seria necessária a conectividade de qualquer região do meio com o restante para que houvesse disponibilidade de condução [105].

Utilizando este modelo como base, Silveira e colaboradores [40], desenvolveram a ideia de que a estrutura que distribui as tensões interna nas células vivas, o citoesqueleto, pode ser caracterizado e modelado a partir de dois parâmetros típicos da teoria de percolação: probabilidade de ocupação e comprimento das fibras. Tal como a integridade de uma estrutura tipo sólida é necessária para a transmissão rápida de sinais mecânicos entre longas distâncias intracelulares, a célula necessita de uma conexão do seu citoesqueleto de uma extremidade a outra para manter sua integridade estrutural [40,112]. Neste trabalho, os pesquisadores investigaram a implicação da organização do citoesqueleto variando as distâncias de conexão que se mantêm próximas do limiar de percolação [40].

Assim, o citoesqueleto foi modelado como uma rede de ligações entre nós, em uma rede bidimensional de tamanho $L \times L$. Essas ligações representam as fibras de actina do citoesqueleto, enquanto que os nós representam adesões focais, que nada mais são do que organizações complexas de proteínas no citoplasma e na superfície da célula no qual os filamentos podem se ancorar [40]. A probabilidade, $P_{i, j}$, de uma ligação para conectar os nós $i$ e $j$, é dada por:

$$
P_{i, j}=p\left(\frac{1}{d_{i, j}}\right)^{s}
$$

onde $d_{i, j}$ é a distância entre os nós $i$ e $j, p$ é a probabilidade de conexão entre os primeiros vizinhos e o expoente $s$ regula a distribuição de comprimento das ligações. 
Melhor analisando o expoente $s$ pela Eq.(1.26), vemos que quando $s \rightarrow \infty$, apenas primeiros vizinhos com $d_{i, j}=1$ podem ser conectados por uma ligação. Quando $s=0$, a probabilidade de conexão entre dois nós é independente da distância $d_{i, j}$. Valores de $s$ intermediários a estes dois extremos podem gerar redes de todos os tipos. Desde redes que favoreciam ligações de curto alcance a redes que favoreciam ligações de longo alcance [40]. Neste trabalho, os pesquisadores construíram redes para um conjunto de expoentes desde 0 até $\infty$ para diferentes tamanho de sistemas $L$ e um de seus resultados mostra a distribuição relativa do comprimento das ligações entres os nós para diferentes valores de $s$.

Com isto, os pesquisadores proporiam que células sujeitas a grandes magnitudes de estiramento possuem conexões entre as fibras de actina mais longas do que células adaptadas a ambientes mais rígidos. Mostraremos que nossos resultados de análise de imagens corroboram com os obtidos por este modelo de percolação, no que concerne à distribuição de comprimento das fibras de actina. 


\section{Objetivo}

Determinar as razões físicas relevantes para as alterações viscoelásticas observadas em células vivas. Da seguinte forma:

Montar uma plataforma de análise de imagem de células obtidas por microscopia confocal que seja capaz de:

1) Quantificar o alinhamento das fibras de actina evidenciada nas imagens;

2) Calcular a dimensão fractal das células da imagem para analisarmos sua organização estrutural;

3) Quantificar a distribuição de comprimento das fibras de actina das células;

4) Estudar o modelo teórico de percolação para interpretar os resultados.

O desenvolvimento da plataforma de análise de imagem proposta nesta dissertação pode contribuir para o entendimento de alterações estruturais em células, e com isso, poder correlacionar os dados obtidos com medidas experimentais da viscoelasticidade de células. 


\section{Metodologia}

Nesta seção, os procedimentos experimentais utilizados para cultura e isolamento de células, marcação de actina e aquisição da imagem, encontram-se detalhados no Anexo I. Estes procedimentos experimentais foram realizados pela aluna de Doutorado, Carla Dinardo, da Faculdade de Medicina de São Paulo, em parceria com nosso grupo. Nosso trabalho consistiu em todo desenvolvimento teórico da plataforma de análise de imagem, interpretação e correlação dos resultados com suas propriedades mecânicas.

\subsection{Processamento e análise das imagens}

A plataforma de análise de imagens foi desenvolvida em ambiente MATLAB R2012a 64-bit em um computador (Macintosh) Intel Core i7 de $2.3 \mathrm{GHz}$ com quatro núcleos e 4GB RAM. O desenvolvimento da nossa metodologia de quantificação do índice de alinhamento das fibras de actina da imagem via detecção de bordas, fundamentou-se nos trabalhos de Yoshigi et al. e de Kemeny et al., [50,93]. Também analisamos a distribuição de comprimento das F-actina da imagem via componentes conectados, assim como, a dimensão fractal, $D_{f}$, das células pelo método de box counting [54,56]. Todas as análises foram realizadas em imagens no formato Tiff, sem compressão, obtidas por microscopia confocal de CVML de diferentes leitos arteriais sendo, 8 imagens da artéria da aorta abdominal e 10 imagens de cada uma das seguintes artérias: femoral, renal, mamária, carótida, aorta torácica e coronária. 


\subsection{Quantificação da Dimensão fractal}

O processo de quantificação das imagens envolveu três passos básicos. No primeiro passo, realçamos o contraste da imagem em escala de cinza, para melhor evidenciarmos as fibras de actina. Este passo é frequentemente utilizado em processamentos de imagens, pois, realça o brilho da imagem e melhora os resultados do passo seguinte que se refere à eliminação do ruído de fundo [46,50,56,93]. Este realce é feito aumentando ou diminuindo a intensidade do pixel, caso ele represente um objeto ou região de fundo, respectivamente. Em nossas imagens, variamos da intensidade do pixel em $1 \%$ acima e a baixo do seu valor inicial, pois, este valor altera muito pouco as características da imagem e melhora significativamente os resultados obtidos.

No segundo passo, eliminamos o ruído de fundo da imagem. Um método muito utilizado para esta finalidade é o método de Otsu [44,46,50,95,113-115]. Esta metodologia utiliza funções do tipo Gaussianas para gerar um histograma da distribuição de pixels de fundo e pixels do objeto e, com isto, encontrar um limiar de corte, $L_{c}$, que minimize a variância entre as distribuições [116]. Este valor de $L_{c}$, é utilizado para eliminar o ruído de fundo, onde valores de pixel inferiores à $L_{c}$ são substituídos por zero. Porém, para o nosso caso, o método de Otsu gerou um limiar muito alto para todas as imagens analisadas, eliminando várias regiões de fibras significativas para a análise, conforme Figura 14(B).

Devido a isto, desenvolvemos um algoritmo de eliminação do ruído de fundo mais conservador. Em nossa metodologia, o valor de $L_{c}$ correspondia a uma porcentagem do valor máximo do pixel na imagem e era fixo para todas elas. Assim, pixels com valores menores que $L_{c}$ eram substituídos por zero. Dessa forma evitamos eliminar muitos pixels referentes a fibras das análises posteriores, aumentando assim nossa estatística sem levar em conta o ruído.

A fim de estimar como a imagem é sensível ao corte de ruído de fundo, testamos diversos valores de $L_{c}$, conforme Figura 14. Nesta imagem, em C, D, E e F, os valores de $L_{c}$ variaram de $20 \%, 10 \%$, $5 \%$ e $3 \%$ do valor do pixel máximo, respectivamente. Comparando com a imagem original, Figura 14(A), tanto o método de Otsu (Figura 14(B)), quanto valores de $L_{c}$ de $20 \%$ e $10 \%$ (Figura $14(\mathbf{C})$ e (D), respectivamente), eliminaram várias regiões de fibras da imagem. Isto leva a uma perda de informação e 
interfere nos resultados finais das análise das imagens. No entanto, usando um $L_{c}$ de $5 \%$ e de 3\% (Figura 14(E) e (F), respectivamente), praticamente não se elimina fibras. Portanto, com o intuito de poder eliminar o ruído de fundo evitando perder informações relevantes sobre as fibras, escolhemos um $L_{c}$ de $5 \%$ do pixel máximo, visto que valores próximos a este geram resultados semelhantes.
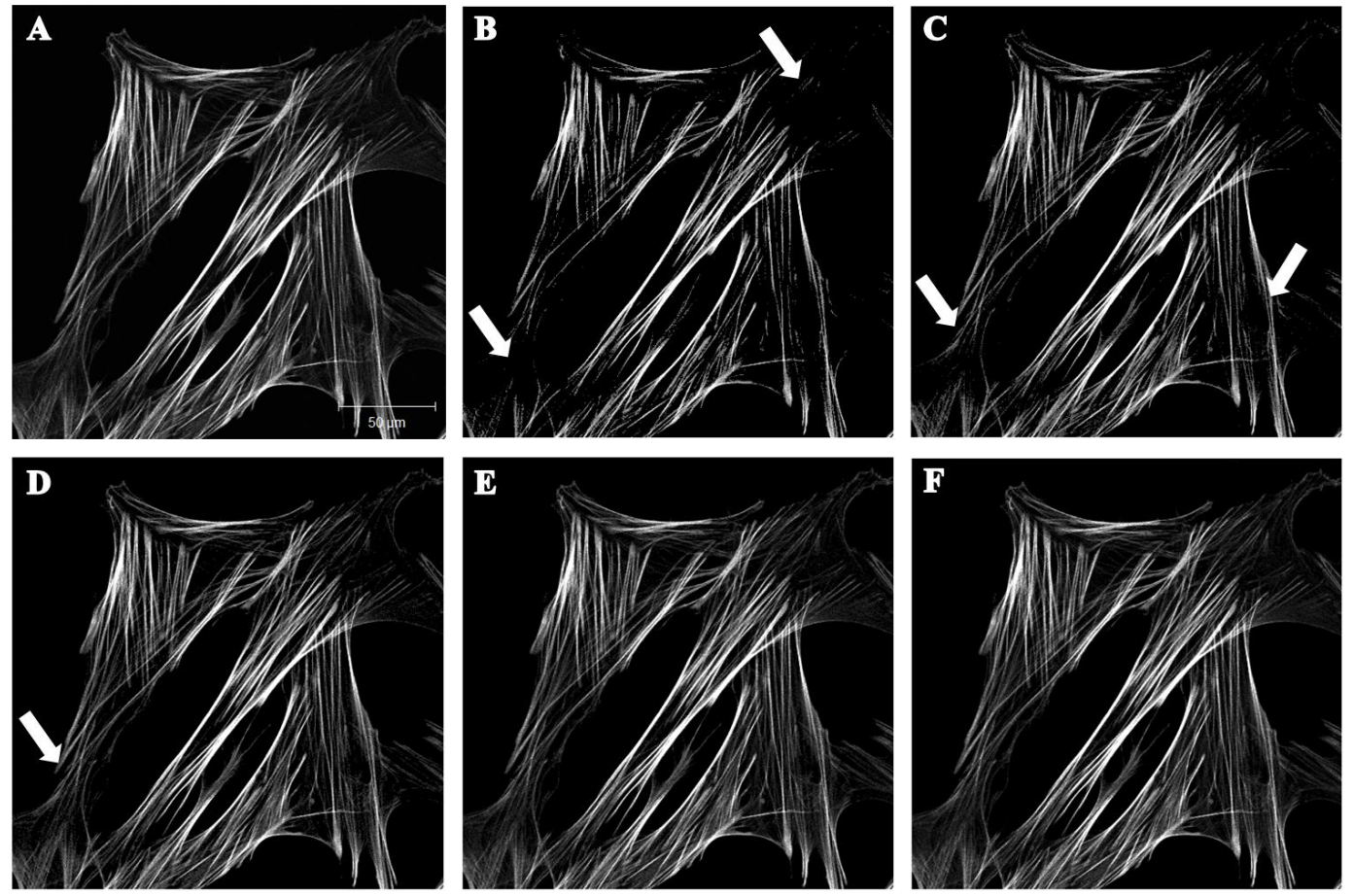

Figura 14: Teste do limiar de corte. A: imagem de entrada. B: imagem resultando do corte de ruído pelo método de Otsu. C, D, E e F: imagens resultantes do corte de ruído utilizando um $L_{c}$ de 20, 10, 5 e $3 \%$ do valor do pixel máximo da imagem $\mathbf{A}$, respectivamente.

O terceiro passo foi criar um método que selecionasse regiões específicas do objeto de interesse, no caso, as células, de forma automatizada. Analisamos estas regiões para determinação do Índice de Alinhamento (IA) e a $D_{f}$, de forma independente do usuário do programa. Para isto, geramos uma imagem binária utilizando o mesmo valor de $L_{c}$ do processo anterior. Neste caso, se o pixel possuísse valor inferior a $L_{c}$, era substituído por zero, caso contrário por um. Portanto, nesta imagem binária, as regiões de fibras possuíam valor um e as regiões de fundo, valor zero.

Esta imagem foi utilizada apenas para selecionarmos as regiões específicas das células. Porém, as imagens que seguiriam para o processamento eram da imagem em 
escala de cinza com os valores dos pixels normalizados entre 0 e 1 . Esta normalização foi realizada dividindo o valor de cada pixel pelo valor do pixel máximo da imagem. Desta forma, os pixels ficaram distribuídos de forma discreta em intervalos de $2^{N_{b}}$, onde $N_{b}$ é o número de bits da imagem, que no nosso caso foi de 8 .

Fizemos uma varredura na imagem binária em janelas, não superpostas, de $L \times L$ pixels. Se a janela contivesse uma quantidade, $N_{p}$, de pixels com valor igual a 1 , onde $N_{\min }<N_{p}<N_{\max }$, a região selecionada pela janela era aceita. Janelas com quantidades $N_{p}$ inferiores à $N_{\min }$, representavam regiões de fundo, enquanto que, quantidades maiores ou iguais à $N_{\max }$, representavam regiões de saturação de fibras na imagem, e eram excluídas da análise. Após testarmos diversos valores de $N_{\min }$ e $N_{\max }$, para várias de nossas imagens, verificamos visualmente, que os valores ideais para se utilizar eram de $1 / 8$ e 1 , respectivamente. Valores em torno desses também geravam bons resultados.

Com esta implementação, calculamos a $D_{f}$ das imagens pelo método de box counting. Para isto, utilizamos janelas quadradas de diferentes tamanhos $L$ para recobrir a região de borda das células da imagem, fazendo $L=2^{i}$, com $i=1,2, \ldots, 6$. Para cada valor de $L$, contávamos quantas janelas eram necessárias para recobrir a superfície das células, e assim, montamos um gráfico do logaritmo do número de janelas, $\log (N)$, pelo logaritmo do inverso de $L, \log (1 / L)$, conforme Eq.(1.25). O coeficiente angular dessa curva representaria a $D_{f}$ da imagem.

Para cada imagem analisada extraiu-se o valor da $D_{f}$. Como para cada leito arterial tínhamos várias imagens, calculamos o valor médio da $D_{f}$ e seu respectivo desvio padrão para cada leito arterial. Montamos um gráfico da $D_{f}$ média por leito arterial. Com isto analisamos o comportamento deste parâmetro de acordo com o tipo de artéria.

\subsection{Quantificação do Índice de Alinhamento}

Para a quantificação do IA das F-actina, utilizamos o operador Sobel. Este operador é capaz de calcular o gradiente de brilho de cada pixel da imagem [90-92]. 
Portanto, para identificarmos as F-actina na imagem, utilizamos as seguintes matrizes de convolução horizontal $\left(M_{h}\right)$ e vertical $\left(M_{v}\right)$ :

$$
M_{h}=\left(\begin{array}{ccc}
-1 & 0 & 1 \\
-2 & 0 & 2 \\
-1 & 0 & 1
\end{array}\right) \quad M_{v}=\left(\begin{array}{ccc}
-1 & -2 & -1 \\
0 & 0 & 0 \\
1 & 2 & 1
\end{array}\right)
$$

Seguindo a metodologia desenvolvida por Yoshigui et al., quantificamos o alinhamento das fibras fazendo uma varredura em toda a imagem, aplicando as matrizes $M_{h}$ e $M_{v}$ pixel a pixel [93]. Para cada pixel $P_{i, j}$ da imagem, em escala de cinza, seus vizinhos foram selecionados em uma matriz amostra $S_{i, j}$.

$$
S_{i, j}=\left(\begin{array}{ccc}
P_{i-1, j-1} & P_{i-1, j} & P_{i-1, j+1} \\
P_{i, j-1} & P_{i, j} & P_{i, j+1} \\
P_{i+1, j-1} & P_{i+1, j} & P_{i+1, j+1}
\end{array}\right)
$$

Desta forma, durante a varredura na imagem, calculava-se o valor da convolução horizontal $\left(H_{h}\right)$ e vertical $\left(H_{v}\right)$ de cada pixel, da seguinte forma:

$$
H_{h}(i, j)=\sum M_{h} \cdot S_{i, j} \quad H_{v}(i, j)=\sum M_{v} \cdot S_{i, j}
$$

Os valores de $H_{h}(i, j)$ e $H_{v}(i, j)$ representam a magnitude do gradiente de brilho ao longo das direções horizontal e vertical, respectivamente. O ângulo $(\theta)$ de cada pixel foi calculado da seguinte forma:

$$
\theta(i, j)=\arctan \left(\frac{H_{v}}{H_{h}}\right)
$$

Ambas as equações (3.3) e (3.4), são conceitualmente idênticas as equações (1.22) e (1.23), apresentadas na Introdução. No entanto, estas são utilizadas em funções de distribuição discreta, enquanto que, aquelas, em distribuição contínua.

Com isso, montamos um histograma com os valores dos ângulos associados a cada pixel entre $90^{\circ} \mathrm{e}-90^{\circ}$, por exemplo, um ângulo de $100^{\circ}$ foi ajustado para $-80^{\circ}$. Em seguida, desenvolvemos um código de cores para podermos visualizar o ângulo dos 
pixels na própria imagem. Assim, associamos uma cor correspondente ao ângulo de cada pixel, de forma que, ângulos mais próximos de $90^{\circ}$, ou seja, fibras verticais na imagem, tinham cor vermelha que diminuía seu brilho exponencialmente até $0^{\circ}$ enquanto que, ângulos mais próximos de $0^{\circ}$, fibras horizontais na imagem, possuíam cor azul que diminuía exponencialmente até $90^{\circ}$ [50,93].

Calculamos o valor de IA para todas as imagens de cada leito arterial. Em seguida, calculamos o valor médio do IA e seu respectivo desvio padrão para cada leito arterial. Montamos um gráfico com este valor em função do leito arterial.

\subsection{Processamento para quantificação da distribuição de comprimento das fibras}

São poucas as referências encontradas na literatura que utilizam de alguma análise de imagem para quantificar o comprimento de fibras. Existe um plugin para o ImageJ, que se propõe a realizar este cálculo, porém, se utiliza de ajustes automáticos para a identificação e cálculo do comprimento das fibras. Como por exemplo, o processo de esqueletização da imagem, no qual removem-se pixels da borda do objeto sem deixar que ele se quebre, e a partir disso, calcula-se o comprimento das fibras [48]. Ou seja, este tipo de processamento calcula o comprimento das fibras de uma imagem muito diferente da original, conforme Figura 16.

Devido a isto, construímos nosso próprio algoritmo para estimarmos o comprimento das F-actina da imagem. Para isso, desenvolvemos uma metodologia diferente da encontrada na literatura. Descreveremos a seguir a parte metodológica inicial dos resultados obtidos com essa nova implementação.

O processamento da imagem para o realce do contraste e eliminação do ruído de fundo, foi idêntico ao descrito na seção 3.2. Eliminado o ruído de fundo, prosseguimos com a identificação do eixo principal de cada fibra evidenciada na imagem. Este processo é importante, pois pode servir como uma representação da imagem original, uma vez que contém toda informação necessária para reconstrução do formato inicial da imagem. 
Para isto, identificamos as bordas da imagem com um processamento similar ao Sobel, porém, utilizamos dois limiares de corte para detectarmos bordas mais e menos intensas. Com isso, bordas menos intensas eram desprezadas caso não estivessem conectadas com as mais intensas. Em seguida, removemos pixels das bordas resultantes para manter apenas seu eixo principal, uma mínima estrutura conectada. Ou seja, como as bordas resultantes são referentes aos pixels de maior intensidade, apenas retira-se os pixels que representariam a espessura da fibra, de forma a manter o comprimento idêntico, porém, com a espessura de um pixel.

Em seguida, removemos os pontos de intersecção para que as fibras sobrepostas pudessem ser identificadas. Com isto, verificamos que restavam na imagem uma quantidade grande de pequenos pixels que, após a identificação do eixo principal, ainda permaneciam na imagem. Portanto, para evitar que esses pixels fossem identificados e posteriormente computados como fibras, quantidades de pixels conectados menores do que um determinado valor, $Q$, eram eliminados da imagem.

A imagem da Figura 15 ilustra a importância de se retirar esse "ruído" remanescente do processo de identificação do eixo principal. Depois de diversos testes, verificamos visualmente que, para nossas imagens, um valor de $Q$ em torno de 20 pixels eliminava de forma satisfatória estes ruídos. Com esta eliminação, evitamos que estes ruídos fossem contabilizados como fibras, melhorando assim nossa estatística. 


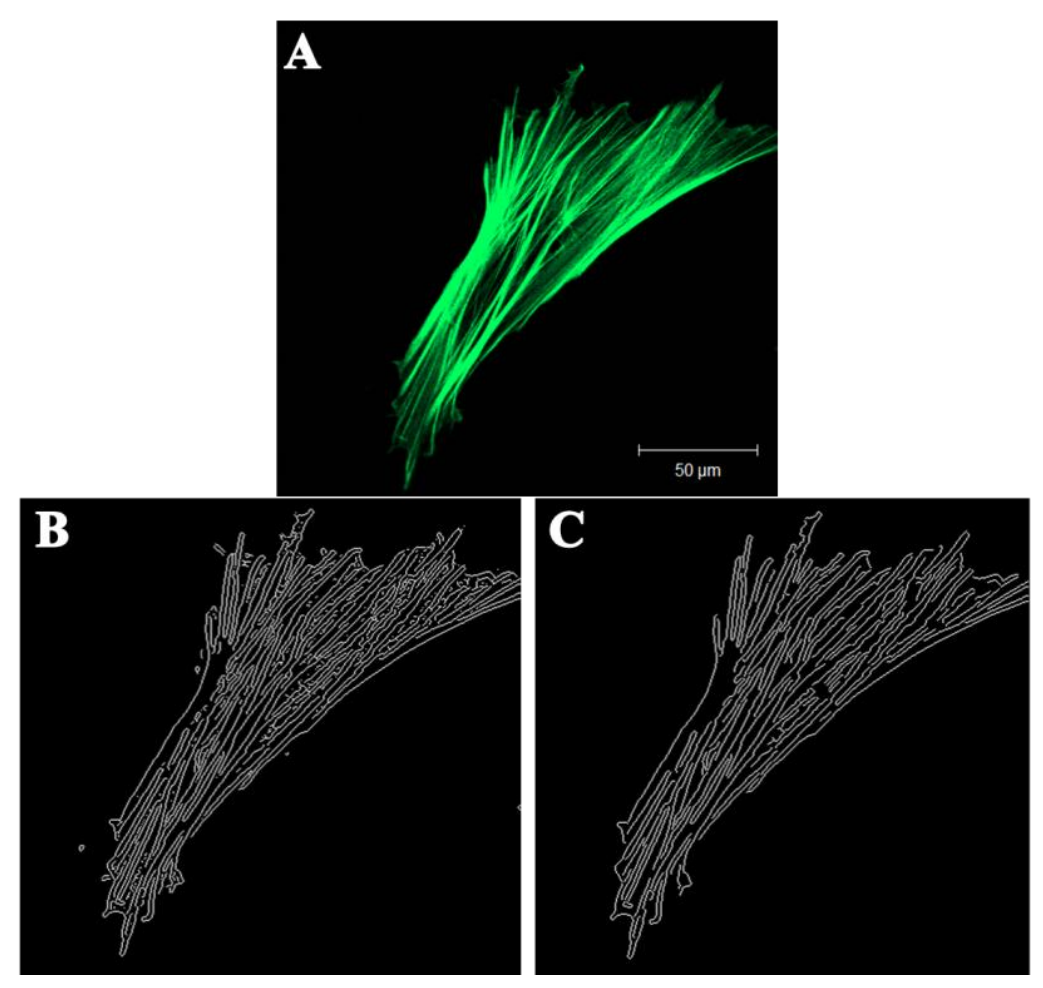

Figura 15: Eliminação de ruído remanescente na identificação do eixo principal. A: Imagem de entrada, neste caso utilizamos uma imagem de CVML da artéria Femoral. B: Imagem após identificação do eixo principal das fibras, ainda com ruído remanescente. C: Imagem após eliminação do ruído, ou seja, quantidade de pixels conectados menores do que 20 foram eliminados da imagem.

Desta forma, conseguimos utilizar uma função que identifica componentes conectados na imagem. Assim, pixels marcados com valor 0, são de fundo, marcados com valor 1, compõem um objeto, ou seja, uma fibra, marcados com valor 2 outra fibra, e assim por diante. Um exemplo da imagem resultante após esse processamento, e o processamento de esqueletização, pode ser visto na Figura 16. Com este processo de identificação das fibras de actina da imagem, geramos um histograma da distribuição de comprimento dessas fibras.

Para cada leito arterial calculamos a distribuição média dos comprimentos, para podermos comparar esta distribuição entre os leitos. Desta forma, comparamos estes resultados com os obtidos do IA e a $D_{f}$ das células, assim como, com a previsão teórica dessa distribuição obtida pelo modelo de percolação para a CVML, proposto pelo professor Dr. Paulo Silveira e colaboradores [40]. 


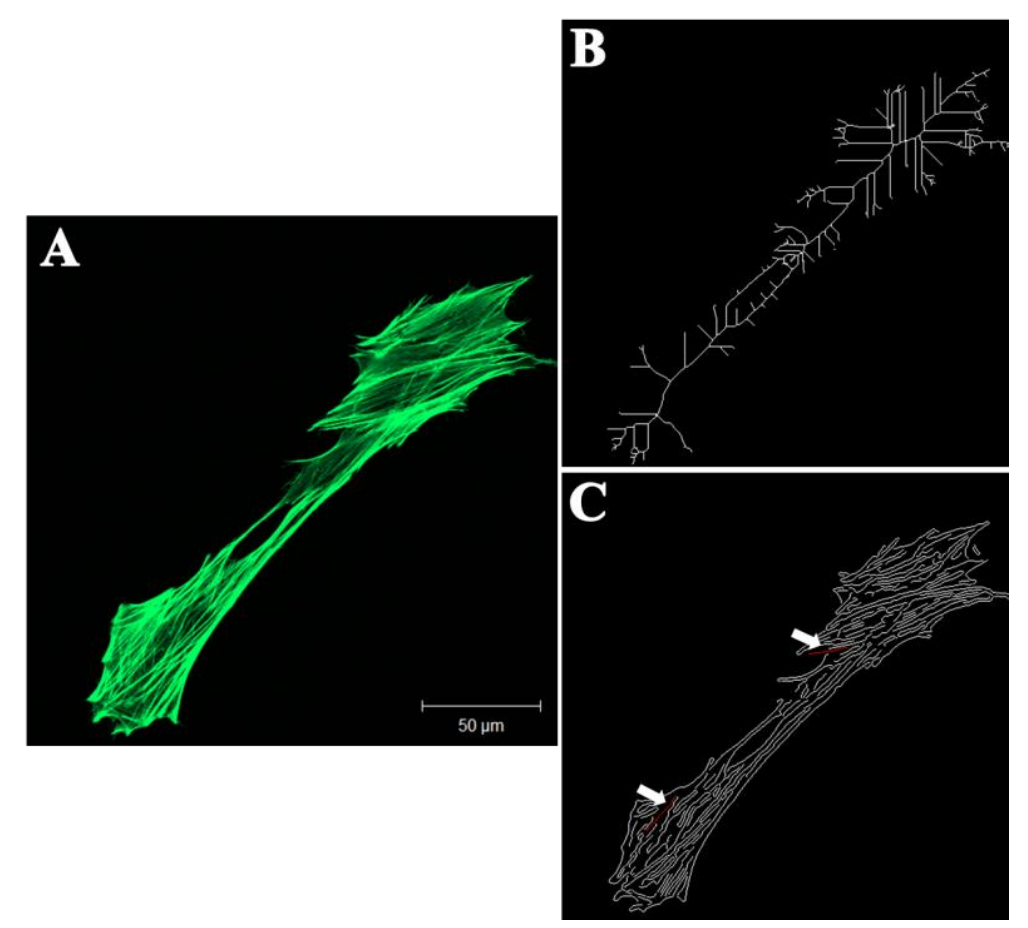

Figura 16: Comparação entre o processo de esqueletização, utilizada pelo ImageJ, e de identificação do eixo principal, desenvolvido pelo nosso algoritmo. A: Imagem de entrada do programa de uma CVML da artéria Aorta Torácica. B: Imagem após o processamento de esqueletização da imagem. C: Imagem após o processamento de identificação do eixo principal das fibras. As setas indicam fibras marcadas em vermelho que ilustram o poder de identificação de fibras que o programa possui.

\subsection{Testes de aplicabilidade da metodologia desenvolvida}

Para verificar a aplicabilidade do algoritmo desenvolvido em nossa plataforma de análise de imagens, realizamos diversos testes, modificando os parâmetros envolvidos. Para a quantificação da $D_{f}$, analisamos como a variação dos valores de limiar de corte, $L_{c}$, e das quantidades $N_{\min }$ e $N_{\max }$, modificavam a distribuição das janelas na imagem. A Figura 17 ilustra alguns dos testes realizados. 

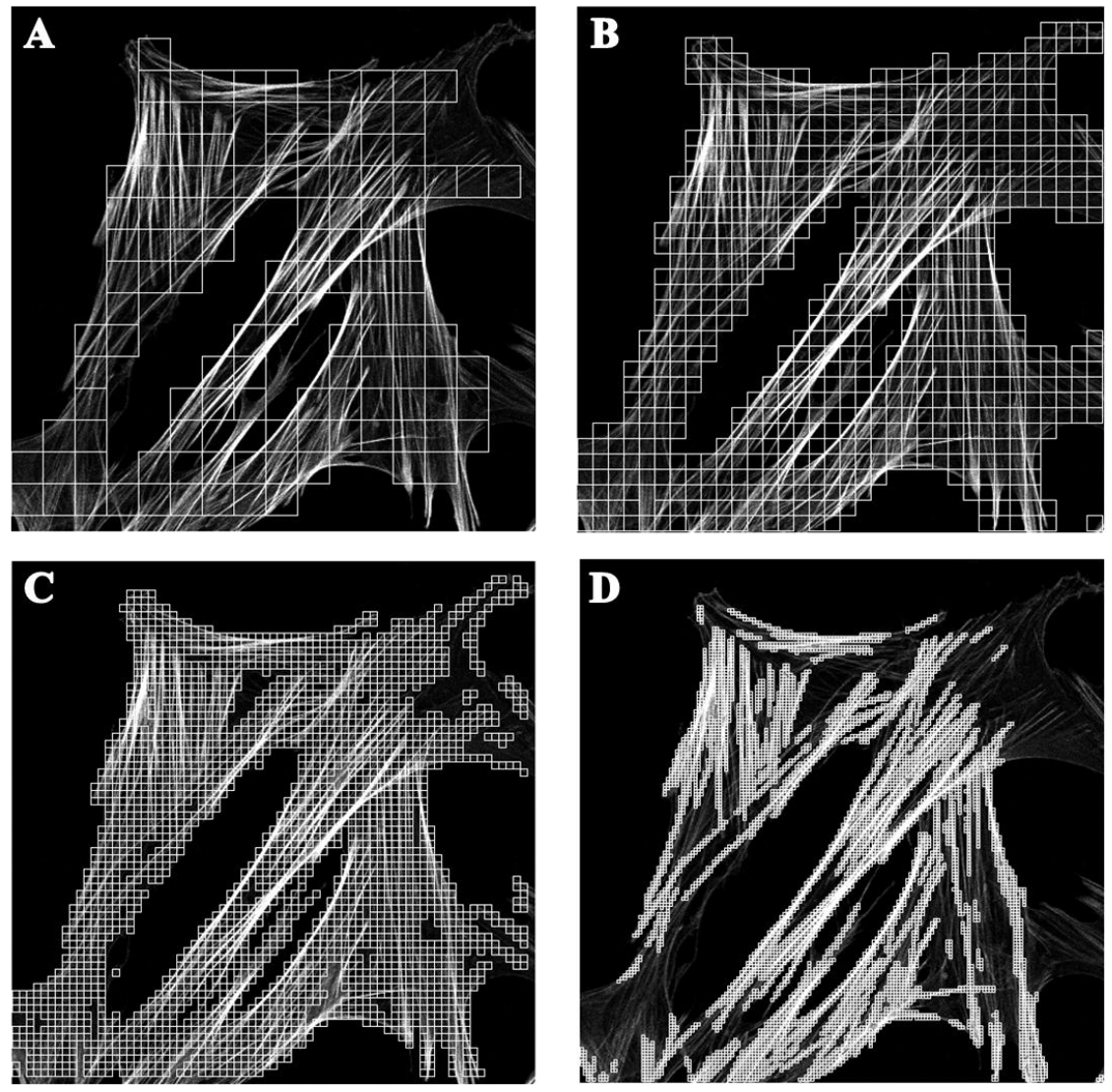

Figura 17: Teste dos parâmetros $L_{c}, N_{\min }$ e $N_{\text {max }}$, para o cálculo da $D_{f}$ das células. Utilizamos como amostra uma imagem de CVML da artéria Coronária. Em A, utilizamos $L_{c}$ de $5 \%$ do pixel máximo e $N_{\min }=1 / 2, N_{\max }=0.9$ e $L=32$. Em B, utilizamos $L_{c}$ de $5 \%$ do pixel máximo e $N_{\min }=1 / 8$, $N_{\max }=1$ e $L=16$. Em C, o valor de $L_{c}$ utilizado foi de $10 \%$ do pixel máximo, com $N_{\min }=1 / 8$, $N_{\max }=1$ e $L=8$. Enquanto que em $\mathbf{D}$, o valor de $L_{c}$ utilizado foi de $30 \%$ do pixel máximo, com $N_{\min }=1 / 8, N_{\max }=1 \mathrm{e} L=4$.

Vemos que, variando o valor de $N_{\min }$ e $N_{\max }$ podemos deixar de analisar regiões de fibras, conforme pode ser visto na Figura 17(A). Já na Figura 17(B), utilizando os valores de $N_{\min }$ e $N_{\max }$ de $1 / 8$ e 1 , respectivamente, vemos que as janelas se distribuem melhor na imagem recobrindo praticamente toda região de fibra. Nas imagens (C) e (D), modificamos o valor de $L_{c}$ para $10 \%$ e $30 \%$ do valor do pixel máximo da imagem, respectivamente. Com estes valores, deixamos de recobrir regiões de fibras da imagem, principalmente com um valor alto como de $30 \%$.

Podemos perceber com estes testes, que utilizando valores adequados de $N_{\min }$, $N_{\text {max }}$ e $L_{c}$, é possível recobrir as regiões de fibras da imagem com confiabilidade, como pode ser visto na Figura 17(B). Por fim, conforme o valor de $L$ diminui, as janelas tendem a se distribuir em regiões de bordas das células, devido a maior probabilidade de se atingir o valor de $N_{\max }$, em janelas menores. 
Para análise da identificação de bordas via método de Sobel, criamos imagens de hastes retas e verificamos se a identificação, o código de cores e o histograma eram reproduzidos com confiabilidade, conforme Figura 18. Nesta figura, temos em A e B as imagens de entrada, que são hastes distribuídas na horizontal, vertical e diagonal. Usando a metodologia descrita, processamos as imagens identificando suas bordas e utilizando o código de cores, conforme A' e B'.

Podemos ver que tanto as bordas quanto o código de cores foram bem executados, mostrando que a metodologia é válida. Os histogramas mostrados em A" e B' são referentes às imagens $\mathbf{A}$ ' e $\mathbf{B}$ ' respectivamente. No histograma de $\mathbf{A}^{\prime}$ vemos um pico em 0 radiano e outro em 1.5 radiano, que estão de acordo com a imagem uma vez que temos apenas hastes verticais e horizontais. Já no histograma de B' vemos um pico a mais em torno de 1 radiano, que representa justamente as linhas diagonais. As pequenas elevações em outros ângulos são dos pixels das extremidades das hastes que também são identificados. Esta imagem mostra que realmente a metodologia é sensível o suficiente para calcular o ângulo dos pixels da imagem com confiabilidade.

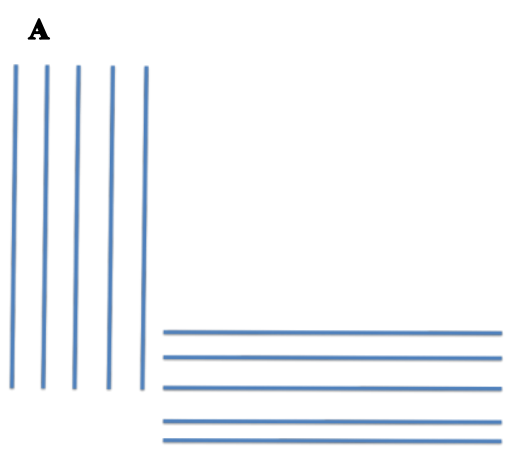

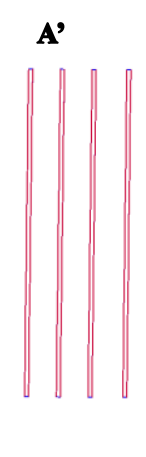

$\mathbf{B}^{3}$
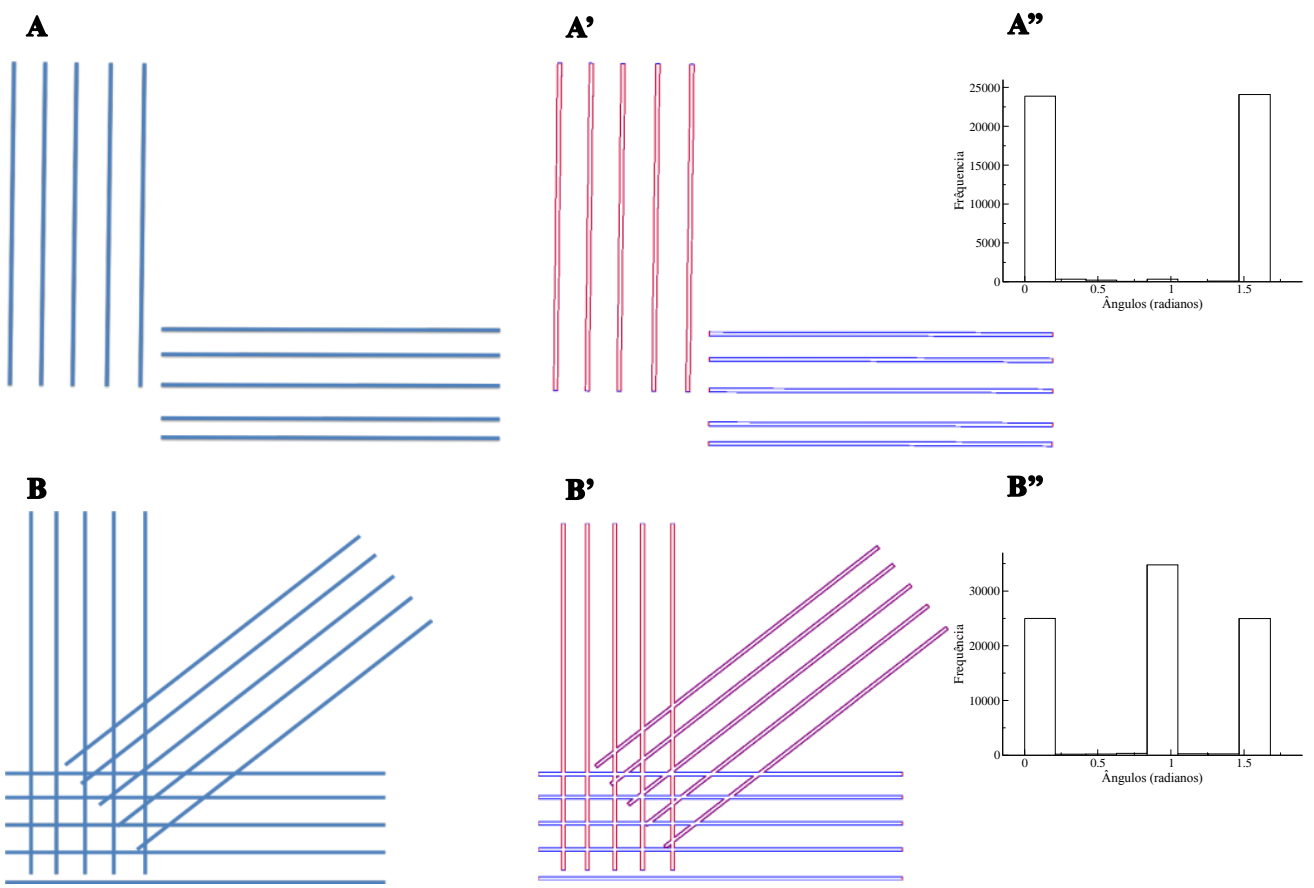

B"

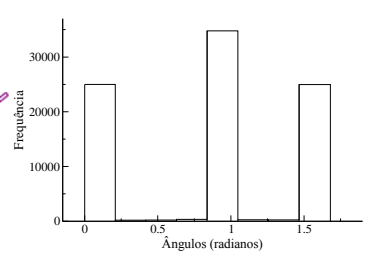

Figura 18: Teste do algoritmo em imagens artificiais. As imagens A e B são imagens de entrada do programa. Em A' e B', temos a imagem resultante após a identificação das bordas e o cálculo dos ângulos com seu respectivo código de cor por pixel. Em A'" e B', temos o histograma resultante da distribuição dos ângulos para cada imagem, mostrando que o algoritmo realmente está operando como desejado. 
Por fim, para verificarmos se a identificação das fibras via componentes conectados, geravam imagens semelhantes à original com o mínimo de ruído possível. Para isto, usamos diversos valores de $Q$, para verificarmos se a imagem resultante apresentava quantidades pequenas de pixels desvinculadas das fibras resultantes, conforme Figura 19. Vemos que essencial utilizarmos um valor de $Q$ adequado, para não computarmos, no processos subsequentes, estes pequenos pixels remanescentes como fibras. Neste contexto, a imagem (D), da Figura 19, é a que melhor elimina este ruído, restando a penas as fibras mais intensas da imagem. O valor de $Q$ utilizado para obtermos esta imagem foi de 20, sendo este, portanto, o que utilizamos em nosso processamento.
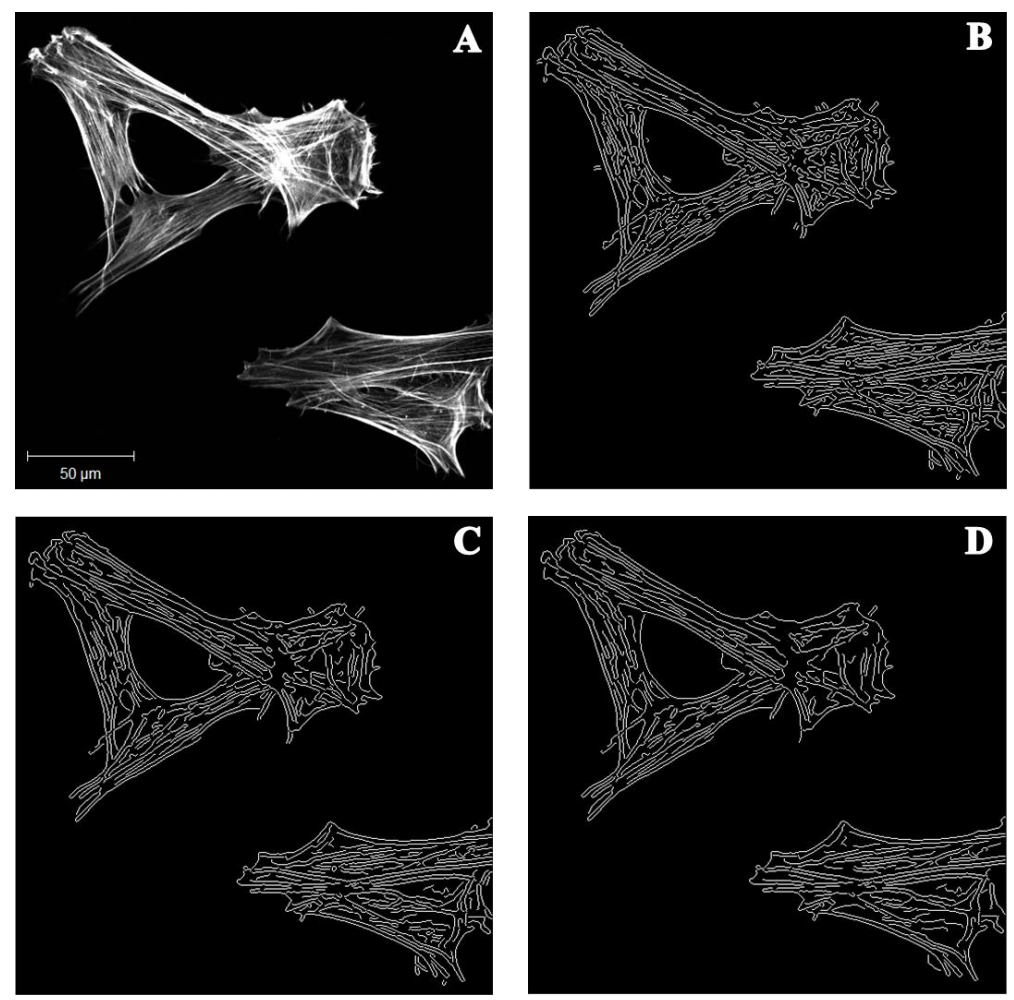

Figura 19: Variação da quantidade, $Q$, para remoção de pequenos pixels interpretados como ruído remanescente do processo de identificação do eixo principal das fibras. Em A, temos a imagem de entrada do programa, que no caso, se refere a uma imagem de CVML da artéria Aorta Torácica utilizada em nossas análises. Em B $\mathbf{B}$ temos a imagem resultante do processo de identificação do eixo principal das fibras, utilizando um valor de $Q=5$. Em $\mathbf{C}$ e $\mathbf{D}$ temos o mesmo tipo de processamento utilizado em $\mathbf{B}$, porém, com valores de $Q=10$ e $Q=20$, respectivamente. 


\section{Resultados}

Nesta seção, abordaremos os resultados da análise das imagens obtidas pela plataforma desenvolvida. Iniciaremos com os resultados do Índice de alinhamento e Dimensão fractal, para em seguida mostrarmos os da distribuição de comprimento das fibras de actina na imagem. Todos estes resultados foram comparados com as propriedades mecânica das células, obtidas no trabalho de Carla Dinarto et al., apresentados na seção 1.5 da Introdução deste trabalho [41].

\subsection{Caracterização morfológica de células vasculares de músculo liso: Índice de alinhamento de Dimensão fractal}

A caracterização morfológica das CVML foi realizada via método de box counting, descrito em detalhes na seção 3.2 da Metodologia. Com a variação do tamanho do lado $L$ das janelas que recobriam as regiões de bordas das células na imagem, fizemos o cálculo da $D_{f}$ das células via Eq.(1.25). Na Figura 20(A), (B) e (C), ilustramos a distribuição das janelas em uma imagem de CVML da artéria renal, para valores de $L$ de 64, 16 e 4, respectivamente. Nestas imagens vemos que conforme diminuímos o tamanho $L$ das janelas, estas tendem a se distribuírem nas regiões de bordas das células, conforme discutido na seção 3.5 da Metodologia. Em D temos o ajuste dos pontos do logaritmo da quantidade de janelas, $N$, pelo logaritmo do inverso de $L$, curva em preto. Cada ponto no gráfico foi obtido para um tamanho de $L$, onde o primeiro ponto corresponde a um $L$ de tamanho 64 pixels, os seguintes foram obtidos para $L$ de tamanho $32,16,8,4$ e 2 pixels, respectivamente. 

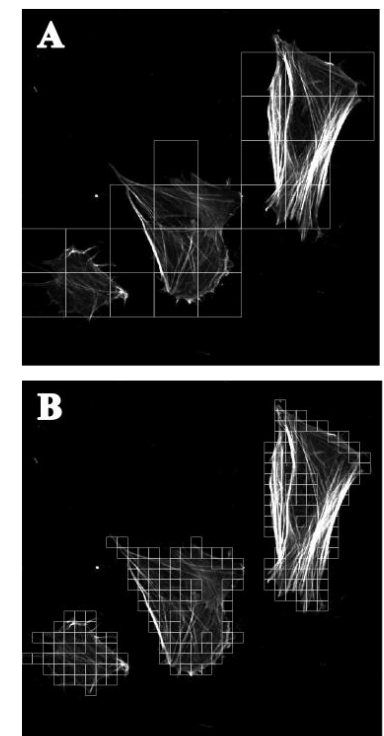

\section{D}
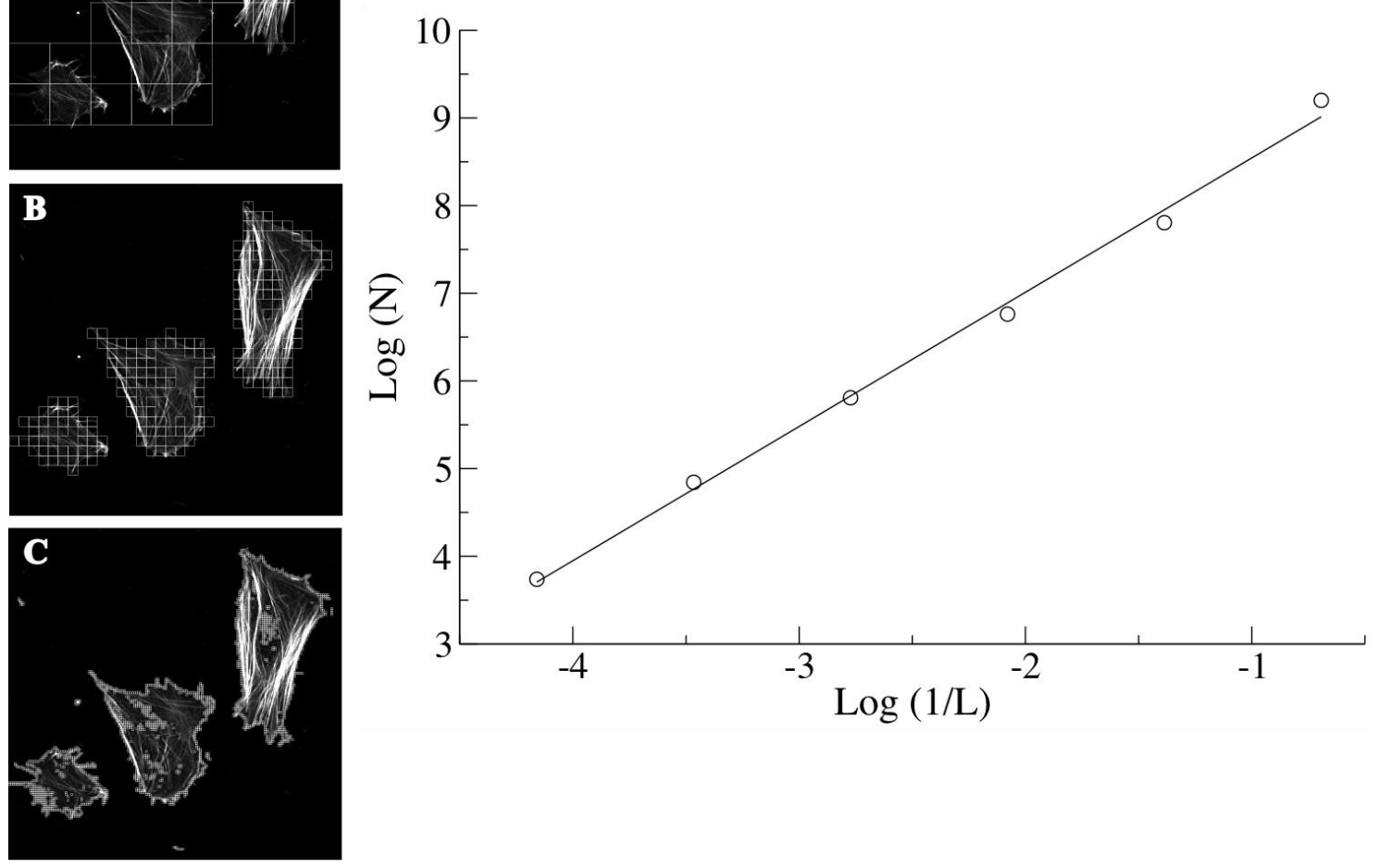

Figura 20: Estimativa da $D_{f}$ obtida pelo método de box counting. com o tamanho, $L$, das janelas variando de 64 a 2 pixels. Para janelas de tamanho, $L$ igual a 64, 16 e 4 pixels, destacamos uma das imagens de CVML da artéria Renal, utilizadas para o cálculo, em $\mathbf{A}, \mathbf{B}$ e $\mathbf{C}$, respectivamente.

Para cada imagem foi construído um gráfico deste tipo e calculado o coeficiente angular da curva que ajustava os pontos, onde este coeficiente era à $D_{f}$ da imagem. Portanto, cada leito arterial possuía um valor de $D_{f}$ para cada imagem. Para podermos comparar a $D_{f}$ de cada leito, calculamos o valor médio de $D_{f}$ por leito arterial, com seu respectivo desvio padrão.

Utilizando o procedimento descrito na metodologia, para o cálculo do IA das fibras de actina, geramos um histograma das regiões locais das células, que eram selecionadas pelas janelas quadradas, durante o processamento das imagens. Para isto, seguimos o critério de seleção das regiões locais de fibras da imagem, como descrito na Metodologia. Identificamos as bordas, via operador Sobel, calculamos o ângulo de cada pixel utilizando a Eq.(3.4) e geramos um histograma de distribuição desses ângulos para a região local selecionada. 
Com este histograma, identificamos o ângulo de orientação preferencial da distribuição e, então, deslocamos este valor para zero. Uma vez que, o que mais nos importava não era o valor deste ângulo, mas sim, como se distribuíam os ângulos a partir dessa orientação preferencial. Devido a isto, deslocamos este valor para $0^{\circ} \mathrm{e}$ redistribuímos o histograma entre $-90^{\circ}$ e $90^{\circ}$. Em seguida, geramos um histograma da distribuição média dos ângulos deslocados de cada região local da imagem, conforme Figura 21. Desta forma, podemos atribuir a cada imagem apenas um histograma, que representa a distribuição média dos ângulos em regiões localizadas da imagem.

A partir deste resultado, geramos o módulo da distribuição, restringindo os valores dos ângulos $0^{\circ}$ e $90^{\circ}$. Com isso, foi possível observar um comportamento exponencial do módulo dos ângulos. Desta forma, calculamos o logaritmo da frequência da distribuição, obtendo o coeficiente angular da curva, conforme Figura 21. O valor desse coeficiente é o que chamamos de IA.

Nesta figura, temos em A e $\mathbf{A}^{\prime}$ a imagem de entrada e seu histograma de distribuição dos ângulos, respectivamente. Esta distribuição de ângulos foi gerada para a imagem como um todo. Desta forma não se evidencia um alinhamento preferencial das fibras da imagem, pois, os ângulos estão distribuídos de forma relativamente uniforme. Apesar de existir um certo alinhamento local na imagem, este alinhamento muda em pontos distintos da imagem, conforme indicado nas setas da Figura 21. Diferente do que acontece com a nossa metodologia, onde, os alinhamentos locais são evidenciados, como pode ser visto no histograma $\mathbf{B}$ ' correspondente à imagem $\mathbf{B}$, da Figura 21. 

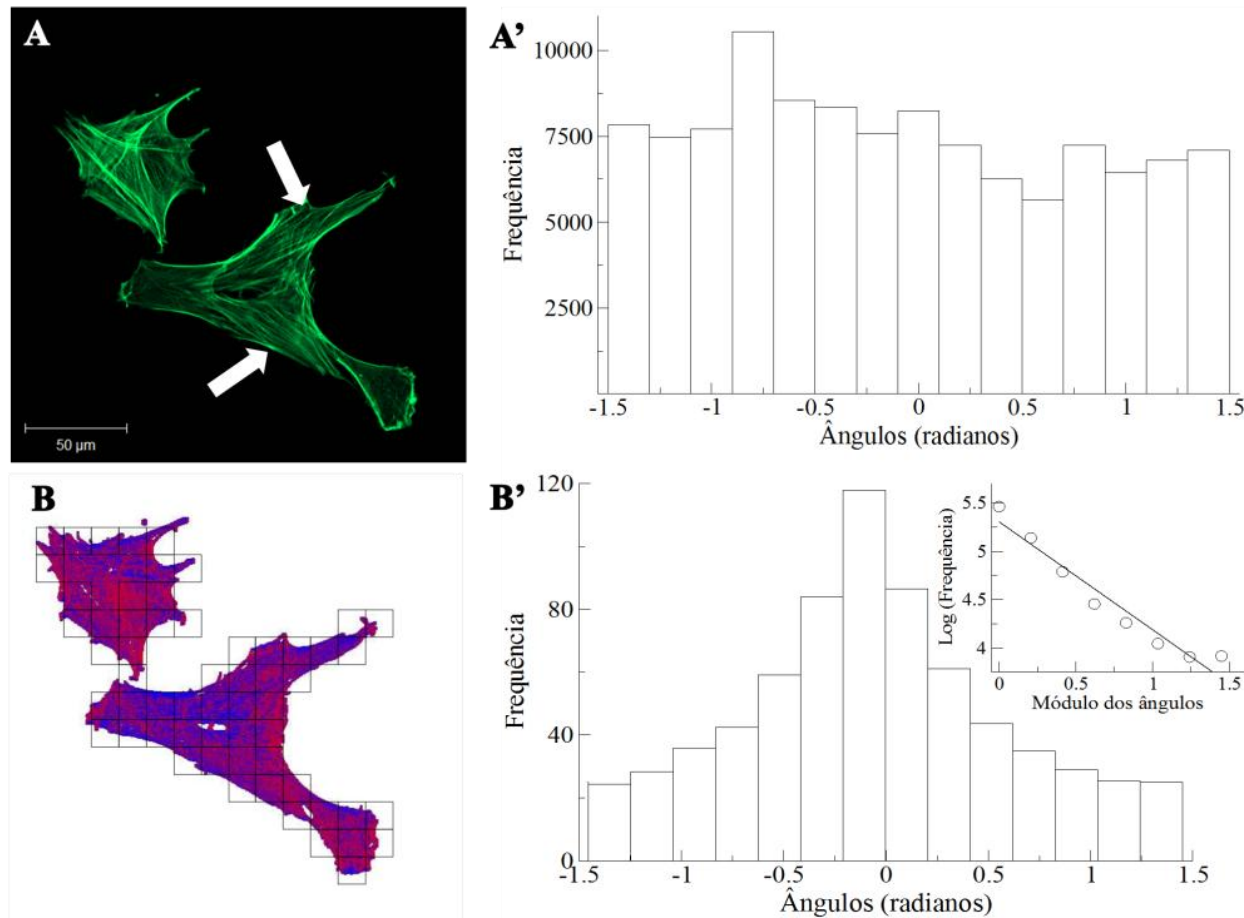

Figura 21: Etapas do processo das imagens. A: Imagem de microscopia confocal de uma CVML da artéria da Aorta Torácica, com magnificação de 40× marcadas com faloidina. As fibras em verde são as fibras de actina. A': Histograma típico da orientação das fibras da imagem inteira. B: Ilustração das janelas quadradas sobre a região de interesse da imagem, distribuídas de forma automatizada. Nesta imagem, os pixels brancos correspondem à regiões sem células da imagem, identificados pelo critério de corte. Pixels em azul e vermelho possuem orientação predominantemente horizontal e vertical respectivamente. B': Histograma correspondente, obtido pela média da distribuição dos ângulos deslocados da orientação preferencial, para cada caixa. Inset: O IA correspondente ao coeficiente angular da curva em preto que ajusta os pontos.

Esta imagem ilustra etapas do nosso processamento, onde, a região branca, corresponde ao fundo da imagem. Esta região de fundo foi devidamente identificada no corte do ruído e retirada da análise. Nesta imagem, ainda podemos ver as cores associadas a orientação das fibras identificadas, e as janelas quadradas distribuídas sobre as fibras de actina das células. Em B', temos o histograma obtido do processamento de análise local da distribuição. Observamos uma distribuição quase simétrica dos ângulos em torno de $0^{\circ}$, que é o ângulo preferencial deslocado. Ainda na figura B' em inset, temos o módulo da distribuição com os pontos ajustados pela curva em preto, de onde foi calculado o coeficiente angular, IA.

Para definirmos o tamanho $L$ da janela quadrada que usaríamos para a varredura da imagem para o cálculo do IA, fizemos diversos testes variando seu tamanho e processando as imagens, conforme Figura 22. Fizemos o cálculo do IA para a região quadrada selecionada de tamanhos $L$ de: $64,32,16$ e 8 pixels. O comportamento do IA 
ao longo dos leitos arteriais praticamente não muda, exceto para a artéria coronária, leito este que mais modifica seu valor com a variação de $L$. O desvio padrão para as janelas com $L$ de 16 e 8 pixels é menor quando comparados aos de 64 e 32 pixels.
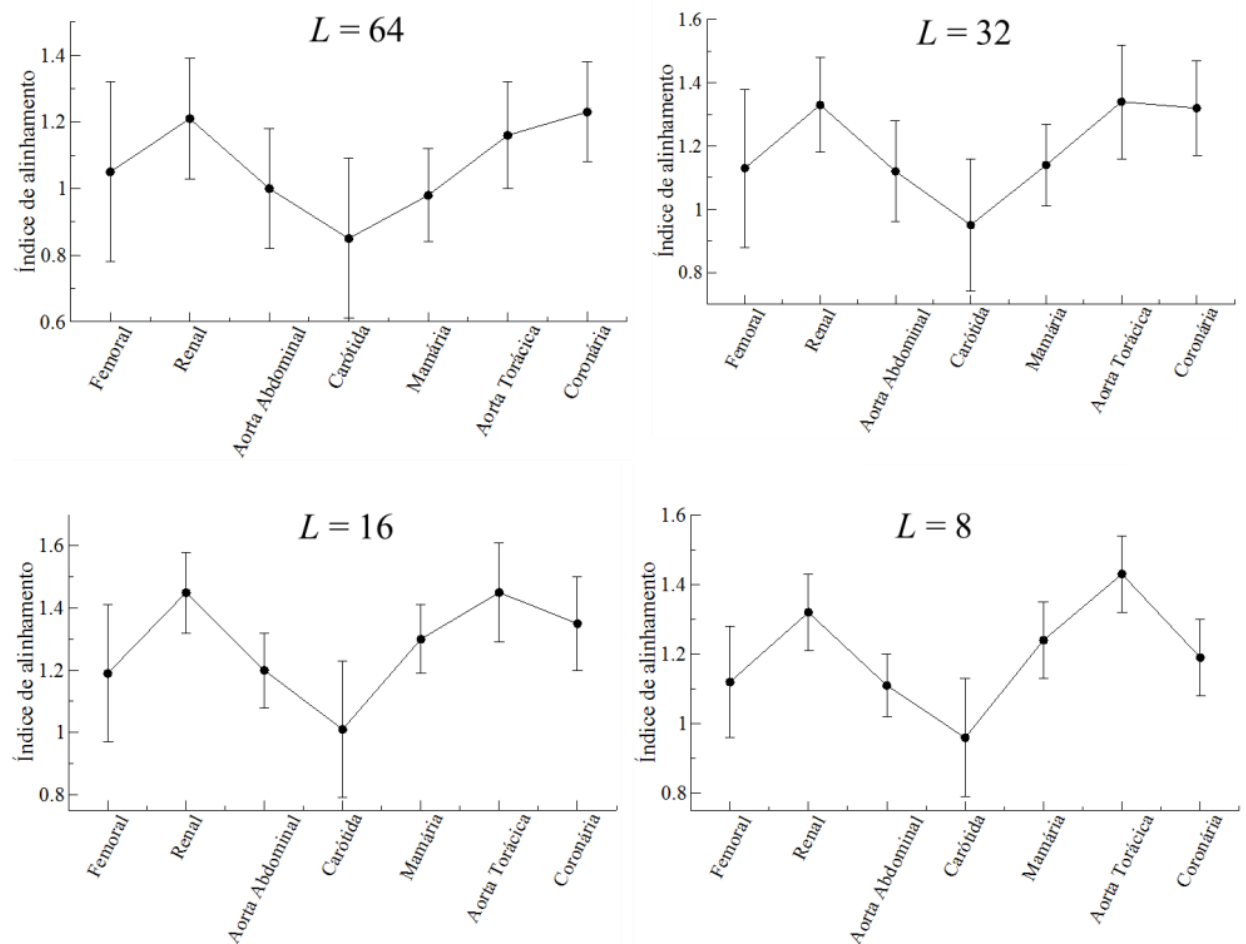

Figura 22: Comportamento do IA com a variação do tamanho da lado, $L$, da janela quadrada.

Devido a esta similaridade de comportamento, exceto para a artéria coronária, decidimos adotar como padrão o tamanho de janela quadrada com $L=32$. Este tamanho engloba melhor as regiões localizadas da amostra, conforme Figura 21(B), pois, capta quantidades menores de regiões sem células, comparada com uma janela de $L$ igual a 64 (ver Figura 20(A)), e evita captar poucas fibras como acontece para $L$ de tamanhos menores (ver Figura 20(B e C)).

Para podermos comparar o IA entre os diferentes leitos arteriais, calculamos seu valor médio por leito e ajustamos um gráfico do inverso deste valor para cada leito, conforme Figura 23. Nesta figura, a curva em azul, representada por linhas pontilhadas e quadrados, se referem ao valor médio da $D_{f}$ de cada CVML analisadas. Enquanto que, a linha preta, representada por linha contínua e círculos, se referem ao valor médio do IA de cada imagem das CVML. No resultado mostrado na Figura 23, temos, portanto, a 
distribuição dos valores médios da $D_{f}$ e do inverso do IA, para melhor analisarmos como estas grandezas se comportam de acordo com o leito arterial a qual pertencem.

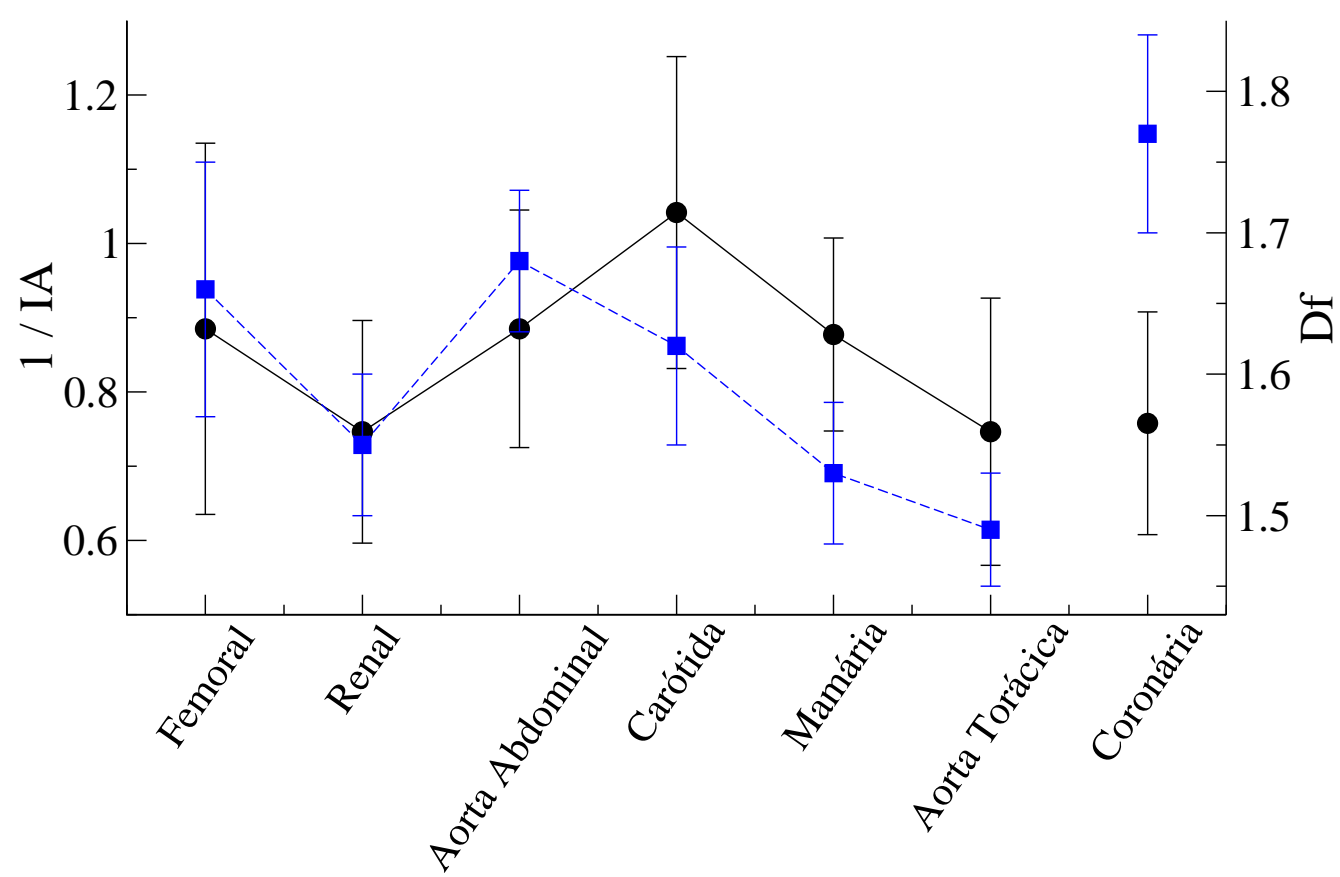

Figura 23: Comportamento do IA de da $D_{f}$ de acordo com o leito arterial. A curva em preto, representada por círculos e linhas contínuas, se refere ao inverso do IA, enquanto que a curva em azul, representada por quadrados e linhas pontilhadas, se refere a $D_{f}$. As artérias estão dispostas em ordem decrescente da distância ao coração, sendo elas: Femoral, Renal, Aorta Abdominal, Carótida, Mamária e Aorta Torácica. O comportamento de IA e $D_{f}$ sugerem uma correlação negativa.

Os leitos arteriais estão distribuídos conforme a sua distância ao coração, indo do mais afastado, CVML da artéria femoral, ao mais próximo, artéria coronária, da mesma forma que no gráfico da Figura 6, apresentado na Introdução deste trabalho. Conseguimos notar uma leve diferença entre o IA das CVML, porém, o desvio padrão é relativamente alto. Conforme nos aproximamos do coração, o IA atinge seu valor mínimo e a partir daí aumenta até seu valor máximo nas CVML da artéria aorta torácica.

Já a $D_{f}$ aparenta um comportamento mais próximo ao de $Z G$ (Figura 6). Da artéria femoral para a renal, a $D_{f}$ diminui e em seguida aumenta na artéria aorta abdominal. Comportamento este que é o oposto do IA. A $D_{f}$ continua diminuindo até 
atingir seu mínimo nas CVML da artéria aorta torácica. Com isto vemos que IA e $D_{f}$ sugerem uma correlação negativa. Novamente, desvinculamos os resultados do IA e da $D_{f}$ para a artéria coronária. Para esta artéria, o IA é praticamente o mesmo da aorta torácica, porém a $D_{f}$ atinge seu valor máximo.

Este resultado pode ter uma correlação com a mecânica do citoesqueleto, conforme resultado da Figura 6 apresentada na subseção 1.5.2 da Introdução. Analisando ambos os resultados, vemos que a rigidez das CVML tende a diminuir quanto mais próximo este leito estiver do coração. Comportamento similar ao obtido para a $D_{f}$, a partir da artéria da aorta abdominal, enquanto que, o IA tende a aumentar a partir da artéria da carótida. Podemos supor que quanto mais rígida for à célula, maior será sua $D_{f}$ e menor o alinhamento das fibras de actina. Se a célula for mais mole o comportamento será o contrário.

Para a $D_{f}$ esta diminuição de valor é mais evidente a partir da artéria aorta abdominal, enquanto que para o IA, ocorre a partir da artéria carótida. A correlação negativa entre estas grandezas fica bem evidente nos três primeiros leitos arteriais, femoral, renal e aorta abdominal. Diferencia-se na artéria carótida e em seguida segue a mesma tendência até a artéria aorta torácica. Por mais que a rigidez das CVML não apresente este comportamento inicial, a tendência de $Z G, D_{f}$ e o inverso de IA são muito similares e podem estar correlacionados.

\subsection{Caracterização morfológica de células vasculares de músculo liso: Probabilidade de distribuição do comprimento das fibras de actina}

Com todas as fibras identificadas, via componentes conectados, calculamos seu perímetro computando a distância entre cada par de pixels adjacentes ao redor de uma fibra marcada, conforme Figura 24. Dividimos o perímetro por dois para obtermos o comprimento da fibra. Para este cálculo, foi essencial eliminarmos a espessura da fibra, pois caso contrário, fibras mais espessas teriam um comprimento maior do que fibras menos espessas. Portanto, nosso algoritmo elimina este tipo de erro para termos um cálculo mais preciso do comprimento das fibras. 


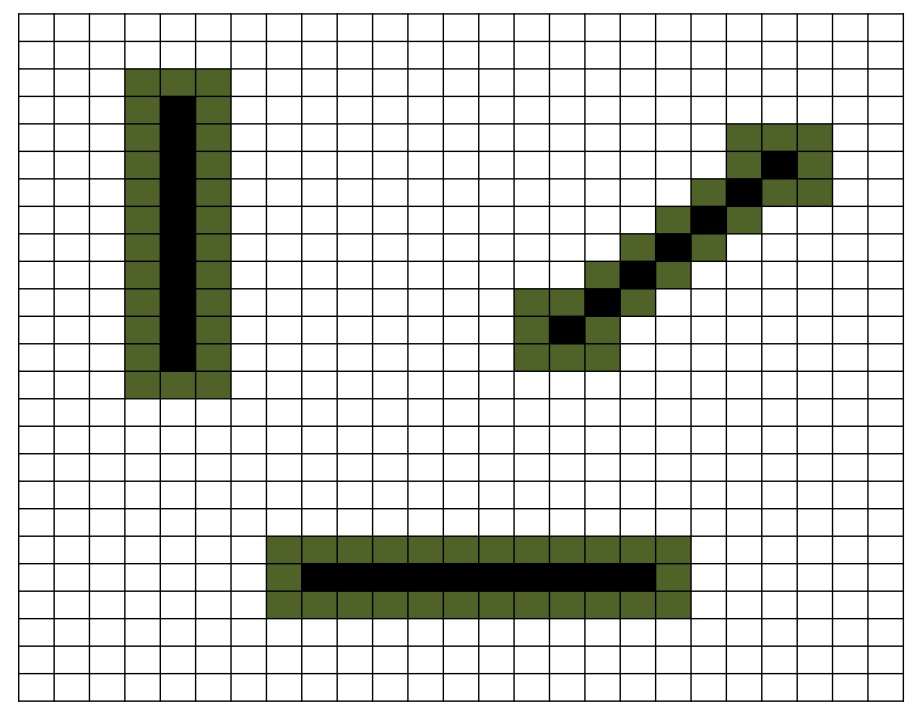

Figura 24: Esquema ilustrativo do cálculo do perímetro das fibras selecionadas. Em preto temos um exemplo de fibras em uma imagem, onde cada quadrado corresponde a um pixel da imagem. Em verde temos os pixels adjacentes a fibras computados para o cálculo do perímetro.

Realizamos este cálculo para cada imagem dos leitos arteriais, em seguida fizemos uma média da distribuição dos comprimentos por artéria. Normalizamos o histograma da distribuição média de comprimentos e igualamos sua integral à unidade. Com isso, obtivemos uma frequência relativa de distribuição dos comprimentos das fibras das células de cada leito arterial, conforme Figura 25. 


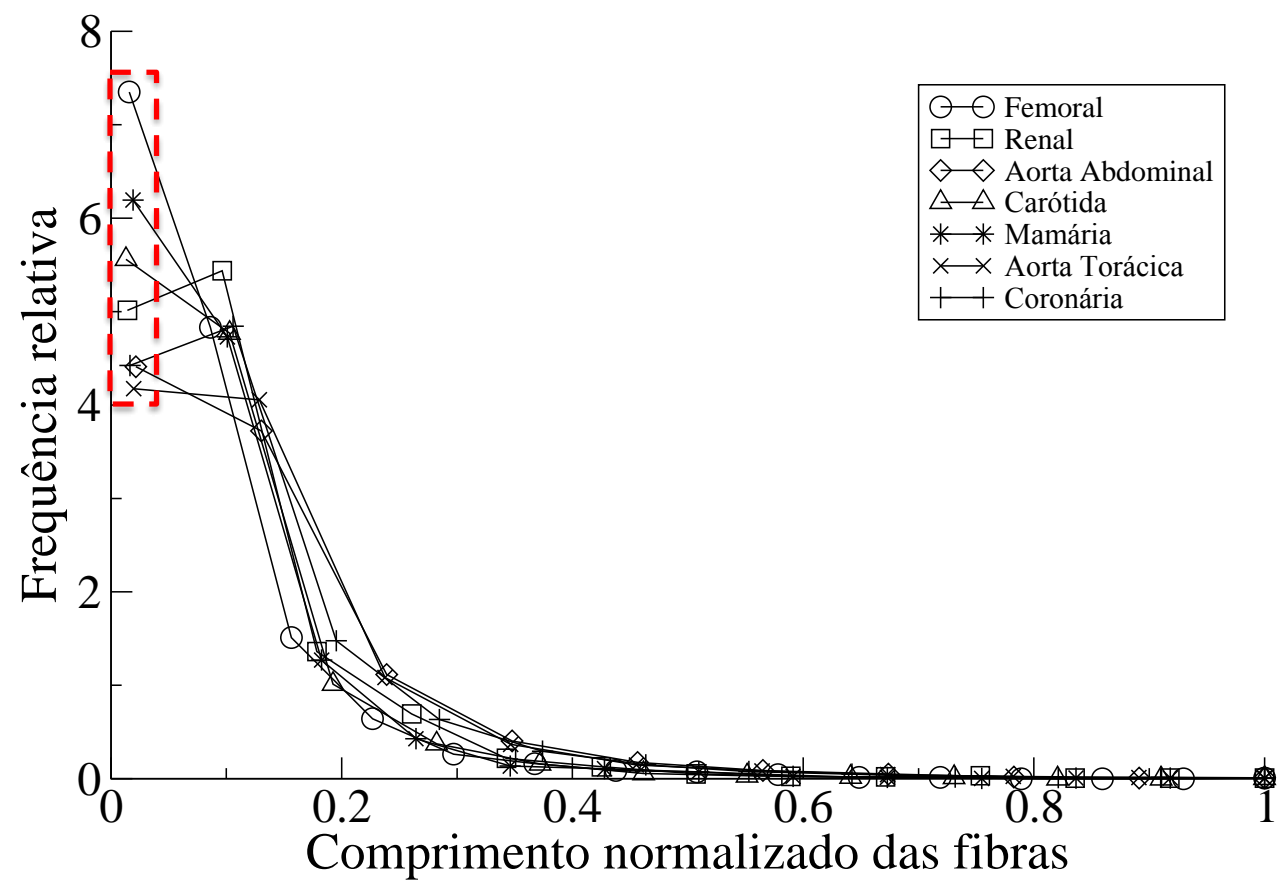

Figura 25: Frequências relativas de comprimentos normalizados das fibras, obtidas pela imagem das células de cada artéria (Femoral, Renal, Aorta Abdominal, Carótida, Mamária, Aorta Torácica e Coronária). Em detalhe a frequência relativa de filamentos curtos (ver Tabela 1).

O gráfico mostra que, a frequência relativa de distribuição para cada leito arterial é praticamente a mesma. Temos uma probabilidade alta de, em uma CVML, encontrarmos fibras de actina de comprimento curto e, uma probabilidade baixa de encontrarmos fibras de actina de comprimento longo. Evidenciamos no gráfico os pontos correspondentes à frequência relativa de comprimentos curtos.

Podemos ver que por mais que a distribuição seja semelhante entre os diferentes leitos, quando analisamos em termos de comprimentos curtos encontramos algumas diferenças. As CVML da artéria femoral são as que possuem uma maior quantidade de filamentos curtos comparadas com as outras artérias, enquanto que as CVML da artéria aorta torácica são as que possuem uma menor quantidade desses filamentos. Para melhor compararmos os valores da frequência relativa de comprimentos curtos para cada leito arterial, montamos a Tabela .

Os valores sugerem que para as CVML da artéria femoral temos uma probabilidade maior de encontrarmos fibras de actina de comprimentos curtos, quando comparada com as demais artérias, enquanto que, para a artéria aorta torácica temos uma probabilidade menor de encontrarmos estes tipos de filamentos. 


\section{Tabela 1}

Frequência relativa de comprimentos curtos por leito arterial

\begin{tabular}{cc}
\hline Células & $\begin{array}{c}\text { Frequência relativa de } \\
\text { comprimentos curtos }\end{array}$ \\
\hline Femoral & 7.35 \\
Renal & 5.01 \\
Aorta Abdominal & 4.41 \\
Carótida & 5.56 \\
Mamária & 6.19 \\
Aorta Torácica & 4.17 \\
Coronária & 4.42 \\
\hline
\end{tabular}

Para melhor evidenciarmos o comportamento da frequência relativa para comprimentos mais longos, calculamos o logaritmo do eixo y da Figura 25, que corresponde à frequência relativa, e montamos um novo gráfico. Para cada leito arterial, os pontos se distribuem praticamente de forma linearmente descendente, conforme Figura 26. Os pontos para as CVML das artérias aorta torácica e aorta abdominal encontram-se mais acima dos demais leitos arteriais. $\mathrm{O}$ que está de acordo com a Tabela , uma vez que estas artérias são as que têm uma menor quantidade de filamentos curtos em suas células, logo uma maior quantidade de filamentos longos. 


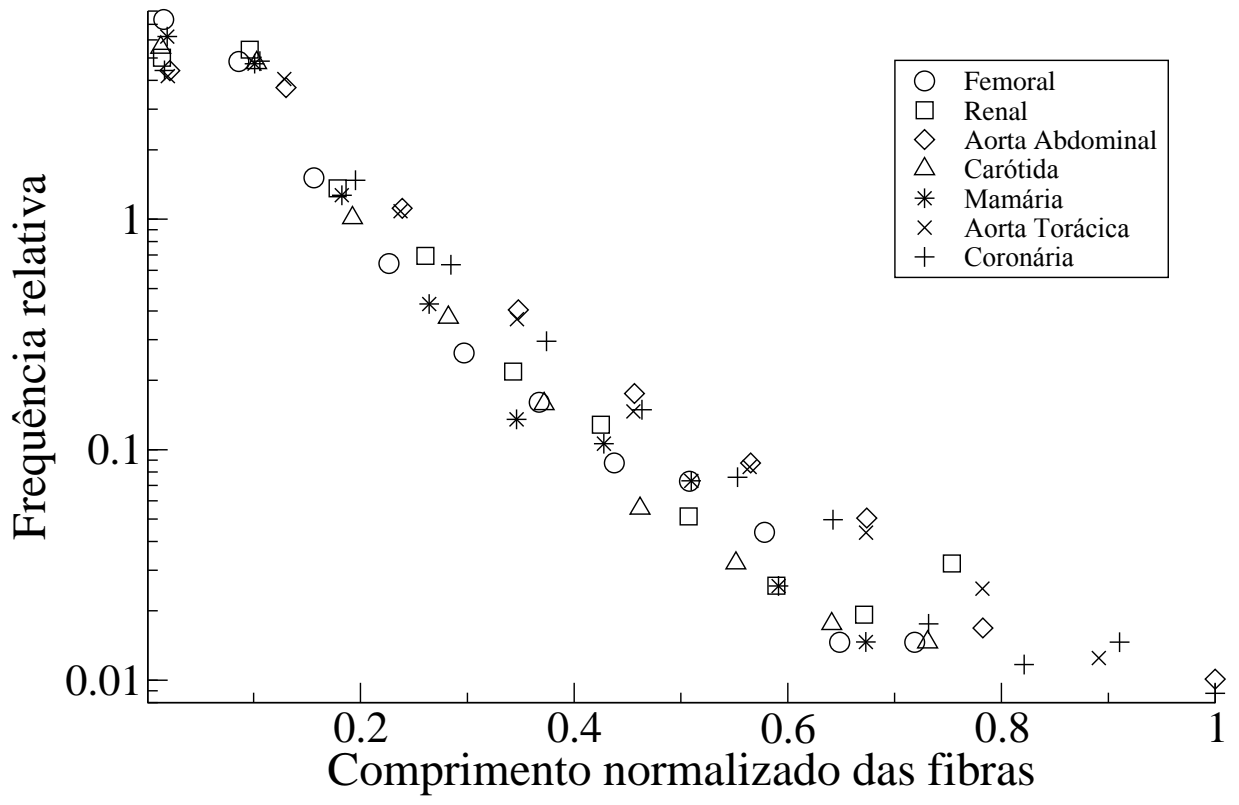

Figura 26: Gráfico com frequência relativa em escala logarítmica, ilustrando o comportamento para filamentos de comprimentos longos. 


\section{Discussão e Considerações Finais}

Neste estudo, demonstramos que podemos correlacionar propriedades mecânicas com estruturais de CVML de diferentes leitos arteriais. Desenvolvemos uma metodologia de análise de imagem inovadora, abordando três aspectos estruturais importantes, que são: o alinhamento, a morfologia e a distribuição de comprimento de fibras. Com esta abordagem é possível comparar células de leitos arteriais diferentes ou até de mesmo leito, porém, sobre condições diferentes, como por exemplo, células sobre efeitos de drogas ou sobre estresse mecânico. Esta possibilidade de comparação é de muita utilidade, pois, possuir uma plataforma de análise de imagens que seja capaz de comparar propriedades estruturais de células sob diversas condições e ainda poder estimar suas características mecânicas, representa uma nova ferramenta de pesquisa.

As características mais importantes da análise de imagens desenvolvida neste trabalho estão relacionadas ao fato dos processamentos serem independentes do usuário do programa, do IA e da $D_{f}$ servirem como parâmetros de comparação entre células, assim como, a metodologia de cálculo da probabilidade de distribuição de comprimentos ser completamente nova e eficaz naquilo que se propõe. Uma análise de imagem independente do usuário é muito importante, pois os resultados obtidos para uma imagem devem ser idênticos, independente dos grupos de pesquisa que a processem.

Analisando a Figura 10, apresentada na Introdução, ambas as áreas selecionadas para a imagem do tecido normal e maligno e a identificação das fibras de colágeno e do epitélio, foram feitas de forma manual. A partir disso, calculou-se o ângulo das fibras e a FFT. Desta forma, as seguintes perguntas podem surgir: se estas mesmas imagens fossem analisadas por outro grupo de pesquisa teriam o mesmo resultado? Se as regiões selecionadas fossem outras, o resultado poderia ser diferente? A análise de imagens feitas por Javier Adur et al, em seu trabalho [55], apresentou bons resultados, porém, as dúvidas levantadas também são coerentes e poderiam ser evitadas com uma análise de imagens independente do usuário do programa.

A nossa plataforma de análise possui em sua essência a ideia de processar imagens de forma totalmente automatizada, ou seja, o resultado fornecido será o 
mesmo, para uma determinada imagem, independente de quem a processe. Uma vez ajustado o tamanho $L$ das janelas quadradas que farão a varredura das imagens e o limiar de corte, $L_{c}$, para o cálculo do IA e da $D_{f}$, o programa inicia o processamento sem nenhuma interferência do usuário.

O método de box counting utilizado para o cálculo da $D_{f}$ mostrou-se simples e eficaz, pois, gerou resultados compatíveis com a rigidez das células. Conforme diminuíamos o tamanho $L$ das janelas, desde um tamanho de 64 pixels até 2 pixels, estas cada vez mais se ajustavam nas bordas das células. De forma que o cálculo da $D_{f}$ nos dá uma ideia de quão rugosa é a superfície da célula, ou seja, quanto maior o valor de $D_{f}$ mais rugosa é a superfície da célula. Portanto, os dados sugerem que leitos mais afastados do coração apresentam uma superfície mais rugosa do que leitos mais próximos ao coração.

Para o cálculo do IA, o desenvolvimento mostrou ser de grande utilidade, pois, faz uma análise minuciosa do alinhamento local das fibras de actina das células gerando um valor que representa o grau de alinhamento dessas fibras na imagem. O IA calculado pelo nosso programa se diferencia dos trabalhos de Yoshigui et al., e de Kemeny et al., mencionados anteriormente [50,93], uma vez que não estamos calculando a orientação das fibras, ou seu ângulo preferencial de orientação, mas sim, o quão alinhadas estão as fibras de actina na célula. Esta é uma diferença sutil, mas muito importante, pois, supondo que tivéssemos calculado a orientação das fibras conforme realizado em [50] e [93], e em uma das imagens as fibras de actina estivessem bem orientadas a $30^{\circ}$ e em outra estivessem a $20^{\circ}$, como poderíamos comparar o alinhamento das fibras entre as imagens? Nestas condições não conseguimos fazer uma análise quantitativa do grau de alinhamento das fibras de actina das imagens e compará-las entre si.

Neste sentido fica claro que o IA calculado no nosso programa é um parâmetro que nos diz se as fibras da imagem de uma célula estão mais ou menos alinhadas do que de outra. Em nosso trabalho, analisamos especificamente as fibras de actina de CVML, porém esta análise pode ser expandida para qualquer tipo de fibras, tais como, microtúbulos, filamentos intermediários, entre outros. Outro aspecto importante é o de deslocar o ângulo preferencial da distribuição local para zero. Isto nos permite obter uma distribuição média dos ângulos. Este processamento é crucial para o cálculo do IA das fibras de actina das CVML e se diferencia de outros programas que calculam a distribuição dos ângulos usando o operador de Sobel. 
Além disto, o fato de analisarmos a distribuição dos ângulos em regiões locais das células faz com que seja possível quantificar o alinhamento de fibras em imagens, uma vez que, se fossem analisadas como um todo, nem sempre isto seria possível. Existe um plugin para o ImageJ capaz de calcular a orientação de fibras em uma imagem, chamado OrientationJ. Este plugin gera um histograma de toda a imagem e não de regiões locais de interesse. Devido a esta limitação, este plugin dificilmente observaria o alinhamento de fibras de actina nas imagens analisadas neste trabalho, conforme apresentado na Figura 21 (A'). Isto também justifica o fato de termos optado por desenvolver nosso próprio algoritmo ao invés de utilizar um já existente, como o OrientationJ. Assim, conseguimos modificar a análise e aprimorá-la de forma que nossos resultados apresentam uma variação de alinhamento das fibras de actina entre as CVML dos diferentes leitos e se correlacionam tanto com a rigidez da célula, quanto com a $D_{f}$ e a distribuição de comprimento dessas fibras.

O último parâmetro analisado foi a distribuição de comprimento das fibras de actina nas imagens das CVML. Este tipo de cálculo é importante no sentido de fornecer uma nova forma de se realizar tal análise, pois, difere-se do processo de esqueletização da imagem, como abordado na Metodologia. Esta análise pode ser utilizada para confirmar resultados de simulação computacional, baseada no modelo de percolação. Este modelo, proposto por Paulo Silveira e colaboradores, gera, como um de seus resultados, uma probabilidade de distribuição dos nós de ligação da rede [40]. Neste trabalho os pesquisadores compararam este resultado com a distribuição de comprimentos das fibras de actina da imagem de uma célula disponível na internet, e verificaram que os resultados sugeriam uma correlação, conforme Figura 27.

Cada valor de $s$ corresponde a uma dada distribuição de comprimento dos filamentos ancorados aos nós, geradas aleatoriamente no modelo, e podem ser comparadas com a distribuição de fibras de actina de uma imagem, como pode ser visto na Figura 27 (B e C). Existe um acordo razoável entre a predição do modelo e os dados da imagem, sugerindo que células vivas regulam seu citoesqueleto em torno de $s=2$ [40]. 
$\mathbf{A}$

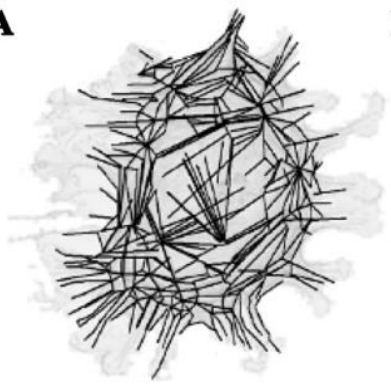

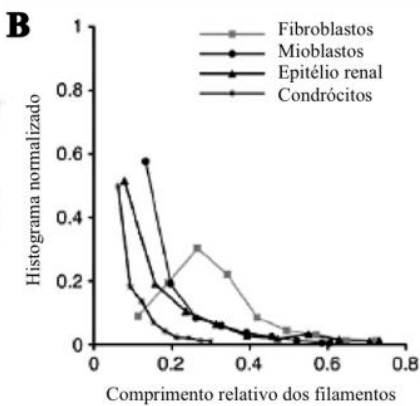

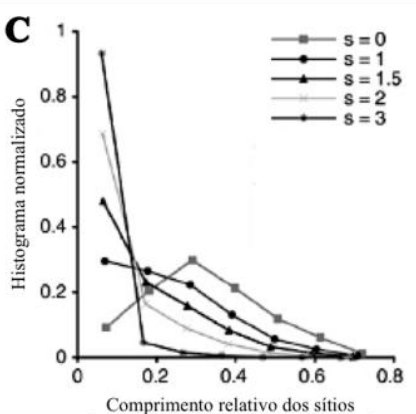

Figura 27: Comparação entre a predição teórica da distância relativa entre os sítios de uma rede no modelo de percolação, com a distribuição relativa de filamentos de uma imagem publicada na internet. A: imagem publicada da internet de uma célula utilizada no processamento. B: Distribuição do comprimento dos filamentos obtida pela imagem da célula. $\mathrm{O}$ comprimento dos filamentos foi normalizado pelo eixo principal da célula. C: Distribuição do comprimento dos sítios da rede obtido por simulação computacional baseada no modelo de percolação, para vários valores de $s$. O comprimento entre os sítios foi normalizado pelo comprimento diagonal da rede (Imagem adaptada de [40]).

Conforme visto na Figura 25, nossos resultados também apresentam um acordo razoável com a predição do modelo. Porém, as imagens, por nós analisadas, foram obtidas por microscopia confocal de CVML de diferentes leitos arteriais, sugerindo assim, um resultado mais confiável do que o obtido na Figura 27 (B). Nossos resultados sugerem que as CVML mais rígidas apresentam uma maior quantidade de filamentos curtos, como visto na Tabela 1, para as CVML da artéria femoral, do que células menos rígidas, como as CVML da artéria aorta torácica. Essa probabilidade de distribuição de comprimentos obtida na Figura 25, mostra que o modelo de percolação pode servir como uma boa aproximação computacional para simular o comportamento de CVML. Estes dados estão estritamente correlacionados com a rigidez, $Z G$, o IA e a $D_{f}$ das CVML analisadas neste trabalho.

A correlação entre a probabilidade de distribuição das fibras de actina, a $D_{f}$, o IA e $Z G$ sugere que quanto mais rígidas forem as células, maior será sua $D_{f}$ e quantidade de filamentos curtos, enquanto que, menor será o alinhamento de suas fibras de actina. Células menos rígidas apresentaram um comportamento contrário. Para melhor visualizarmos a relação entre tais parâmetros, construímos uma tabela expondo seus valores para cada leito arterial. 


\section{Tabela 2}

Comparação entre ZG, Frequência relativa de comprimentos curtos, $\boldsymbol{D}_{\boldsymbol{f}}$ e IA

\begin{tabular}{ccccc}
\hline Células & ZG & $\begin{array}{c}\text { Frequência relativa } \\
\text { de comprimentos } \\
\text { curtos }\end{array}$ & $\boldsymbol{D}_{\boldsymbol{f}}$ & IA \\
& \multicolumn{5}{c}{$\begin{array}{c} \\
\text { Femoral }\end{array}$} & $0.575 \pm 0.66$ & 7.35 & $1.66 \pm 0.09$ & $1.13 \pm 0.25$ \\
Renal & $0.3 \pm 0.91$ & 5.01 & $1.55 \pm 0.05$ & $1.34 \pm 0.15$ \\
Aorta Abdominal & $0.026 \pm 0.72$ & 4.41 & $1.68 \pm 0.05$ & $1.13 \pm 0.16$ \\
Carótida & $-0.085 \pm 0.23$ & 5.56 & $1.62 \pm 0.07$ & $0.96 \pm 0.21$ \\
Mamária & $-0.085 \pm 0.39$ & 6.19 & $1.53 \pm 0.05$ & $1.14 \pm 0.13$ \\
Aorta Torácica & $-0.44 \pm 0.51$ & 4.17 & $1.49 \pm 0.04$ & $1.34 \pm 0.18$ \\
Coronária & $0.15 \pm 0.34$ & 4.42 & $1.77 \pm 0.07$ & $1.32 \pm 0.15$ \\
\hline
\end{tabular}

Por mais que ao longo dos leitos arteriais ocorram flutuações, quando comparamos os extremos, CVML das artérias femoral e aorta torácica, vemos uma boa correlação entre os parâmetros. Cada parâmetro estrutural, obtido pela análise das imagens, relaciona-se entre si, e todos estes podem ser afetados pela mecânica celular.

Podemos supor que se as CVML são menos rígidas, mais suave é sua superfície, pois, menor é o valor da sua $D_{f}$ e maior é a quantidade de fibras de actina longas, fazendo com que estas sejam mais alinhadas, conforme visto na Figura 11 da Introdução. Quanto maior o estresse mecânico ao qual a célula esta submetida, maior o alinhamento das fibras de actina [93]. Portanto, somos levados a crer que as CVML mais próximas ao coração estão sujeitas a um estresse mecânico maior do que células mais afastadas. Isso pode explicar o maior alinhamento das fibras de actina das CVML analisadas neste trabalho.

Esse resultado é coerente, uma vez que leitos arteriais mais próximos ao coração recebem um fluxo sanguíneo maior do que os mais afastados, podendo gerar uma dilatação maior do vaso arterial o que sujeitaria as CVML deste leito, a um estresse cíclico maior do que leitos mais afastados.

Além da dilatação do vaso arterial, vários outros fatores podem estar correlacionados com este comportamento, tais como: o diâmetro do vaso arterial, 
quantidade de matriz extracelular, entre outros [41]. Carla Dinardo et al., fizeram uma análise completa destes fatores anatômicos, conforme Tabela 3.

\section{Tabela 3}

Diferenças estruturais e anatômicas entre as CVML estudadas

\begin{tabular}{ccccc}
\hline Células & $\begin{array}{c}\text { Espessura } \\
\text { média }(\boldsymbol{\mu m})\end{array}$ & $\begin{array}{c}\text { Diâmetro } \\
\text { interno }(\boldsymbol{\mu m})\end{array}$ & $\begin{array}{c}\text { \% de } \\
\text { Colágeno }\end{array}$ & $\begin{array}{c}\text { \% de } \\
\text { Elastina }\end{array}$ \\
\hline Femoral & $324 \pm 21$ & $1,645 \pm 12$ & $12.78 \pm 6.57$ & $14.3 \pm 2.9$ \\
Renal & $207 \pm 39$ & $944 \pm 134$ & $24.17 \pm 5.63$ & $9.2 \pm 3.5$ \\
Aorta Abdominal & $318 \pm 16$ & $4,500 \pm 500$ & $12.76 \pm 3.82$ & $12.2 \pm 4.5$ \\
Carótida & $270 \pm 42$ & $1,896 \pm 340$ & $22.34 \pm 8.45$ & $17.4 \pm 5.3$ \\
Mamária & $142 \pm 21$ & $1,924 \pm 244$ & $14.7 \pm 3.5$ & $43.1 \pm 7.7$ \\
Aorta Torácica & $1,242 \pm 56$ & $12,876 \pm 251$ & $18.13 \pm 3.9$ & $56 \pm 2.8$ \\
Coronária & $94 \pm 10$ & $1,284 \pm 90$ & $19.23 \pm 9.9$ & $3.2 \pm 1$ \\
\hline
\end{tabular}

(Tabela modificada de [41])

Analisando os extremos, CVML das artérias femoral e aorta torácica, a primeira possui um diâmetro interno e uma espessura do vaso menor do que a segunda, assim como a porcentagem de colágeno e elastina, proteínas estas estruturais, comumente encontradas em artérias. Logo, tais propriedades anatômicas também influenciam a rigidez das CVML e sua estrutura. Os dados da Tabela 3 apresentam uma coerência razoável com os da Tabela 2, complementando assim o estudo.

As imagens das CVML da artéria coronária mostraram-se um caso a parte em nosso trabalho. Este leito arterial foi o que apresentou uma maior sensibilidade de quantificação do IA conforme variávamos o tamanho das janelas quadradas que recobriam as regiões de fibras das células na imagem, conforme Figura 22 apresentada nos Resultados. Para este leito, quanto menor o tamanho do quadrado, menor o valor de IA. Logo, neste caso, os valores da $D_{f}$ e do IA estão ligeiramente contra a relação proposta nesta discussão. Conforme mencionado, isto pode estar relacionado à sua diferença com relação aos outros leitos arteriais estudados, que recebem o fluxo sanguíneo durante a sístole enquanto este recebe durante a diástole. Porém, este motivo não é suficiente para explicarmos por completo sua diferença e mais estudos devem ser feitos. 
Por fim, a plataforma de análise de imagens desenvolvida neste trabalho pode ser utilizada como uma ferramenta de estudo de vários problemas científicos que diversos grupos de pesquisa podem vir a enfrentar. Portanto, acreditamos que o trabalho apresentado atingiu seus objetivos, pois, através da plataforma de análise de imagens desenvolvida, fomos capazes de mostrar uma relação estrutural com as propriedades mecânicas das CVML analisadas, conforme nossas hipóteses iniciais apresentadas nos Objetivos deste trabalho. 


\section{Referências}

[1] S.S.M. Rensen, P. a F.M. Doevendans, G.J.J.M. Eys, Regulation and characteristics of vascular smooth muscle cell phenotypic diversity, Netherlands Hear. J. 15 (2007) 100-108. doi:10.1007/BF03085963.

[2] G.K. Owens, M.S. Kumar, B.R. Wamhoff, Molecular regulation of vascular smooth muscle cell differentiation in development and disease., Physiol. Rev. 84 (2004) 767-801. doi:10.1152/physrev.00041.2003.

[3] E.M. Rzucidlo, K. a Martin, R.J. Powell, Regulation of vascular smooth muscle cell differentiation., J. Vasc. Surg. 45 Suppl A (2007) A25-32. doi:10.1016/j.jvs.2007.03.001.

[4] G.A. Meininger, K.L. Fehr, M.B. Yates, Anatomic and hemodynamic characteristics of the blood vessels feeding the cremaster skeletal muscle in the rat., Microvasc. Res. 33 (1987) 81-97.

[5] P.W. Alford, A.P. Nesmith, J.N. Seywerd, A. Grosberg, K.K. Parker, Vascular smooth muscle contractility depends on cell shape., Integr. Biol. (Camb). 3 (2011) 1063-70. doi:10.1039/c1ib00061f.

[6] G. Owens, M. Reidy, Hyperplastic growth response of vascular smooth muscle cells following induction of acute hypertension in rats by aortic coarctation., Circ. Res. 57 (1985) 695-705.

[7] M.W. Majesky, Developmental basis of vascular smooth muscle diversity., Arterioscler. Thromb. Vasc. Biol. 27 (2007) 1248-58. doi:10.1161/ATVBAHA.107.141069.

[8] W.T. Gerthoffer, Mechanisms of Vascular Smooth Muscle Cell Migration, Circ. Res. 100 (2007) 607-621. doi:10.1161/01.RES.0000258492.96097.47.

[9] J.E. Hungerford, C.D. Little, Developmental biology of the vascular smooth muscle cell: building a multilayered vessel wall., J. Vasc. Res. 36 (1999) 2-27. doi:25622.

[10] C.P. Heisenberg, Y. Bellaïche, Forces in tissue morphogenesis and patterning., Cell. 153 (2013) 948-62. doi:10.1016/j.cell.2013.05.008.

[11] B.I. Shraiman, Mechanical feedback as a possible regulator of tissue growth., Proc. Natl. Acad. Sci. U. S. A. 102 (2005) 3318-23. doi:10.1073/pnas.0404782102. 
[12] E. Hannezo, J. Prost, J.F. Joanny, Mechanical Instabilities of Biological Tubes, Phys. Rev. Lett. 109 (2012) 018101. doi:10.1103/PhysRevLett.109.018101.

[13] B. Lubarsky, M.A. Krasnow, Tube Morphogenesis, Cell. 112 (2003) 19-28. doi:10.1016/S0092-8674(02)01283-7.

[14] P. Katira, M.H. Zaman, R.T. Bonnecaze, How Changes in Cell Mechanical Properties Induce Cancerous Behavior, Phys. Rev. Lett. 108 (2012) 028103. doi:10.1103/PhysRevLett.108.028103.

[15] M.F. Coughlin, D.R. Bielenberg, G. Lenormand, M. Marinkovic, C.G. Waghorne, B.R. Zetter, et al., Cytoskeletal stiffness, friction, and fluidity of cancer cell lines with different metastatic potential., Clin. Exp. Metastasis. 30 (2013) 237-50. doi:10.1007/s10585-012-9531-z.

[16] M.J. Buehler, Y.C. Yung, Deformation and failure of protein materials in physiologically extreme conditions and disease., Nat. Mater. 8 (2009) 175-88. doi:10.1038/nmat2387.

[17] C.T. Lim, E.H. Zhou, S.T. Quek, Mechanical models for living cells--a review., J. Biomech. 39 (2006) 195-216. doi:10.1016/j.jbiomech.2004.12.008.

[18] C.T. Lim, E.H. Zhou, a. Li, S.R.K. Vedula, H.X. Fu, Experimental techniques for single cell and single molecule biomechanics, Mater. Sci. Eng. C. 26 (2006) 1278-1288. doi:10.1016/j.msec.2005.08.022.

[19] D. Stamenović, Effects of cytoskeletal prestress on cell rheological behavior., Acta Biomater. 1 (2005) 255-62. doi:10.1016/j.actbio.2005.01.004.

[20] R.D. Kamm, Cellular fluid mechanics., Annu. Rev. Fluid Mech. 34 (2002) 21132. doi:10.1146/annurev.fluid.34.082401.165302.

[21] T. Ludwig, R. Kirmse, K. Poole, U.S. Schwarz, Probing cellular microenvironments and tissue remodeling by atomic force microscopy., Pflugers Arch. 456 (2008) 29-49. doi:10.1007/s00424-007-0398-9.

[22] D.E. Discher, P. Janmey, Y.L. Wang, Tissue cells feel and respond to the stiffness of their substrate., Science. 310 (2005) 1139-43. doi:10.1126/science.1116995.

[23] S. Na, G. a Meininger, J.D. Humphrey, A theoretical model for F-actin remodeling in vascular smooth muscle cells subjected to cyclic stretch., J. Theor. Biol. 246 (2007) 87-99. doi:10.1016/j.jtbi.2006.11.015.

[24] N. Wang, K. Naruse, D. Stamenović, J.J. Fredberg, S.M. Mijailovich, I.M. TolićNørrelykke, et al., Mechanical behavior in living cells consistent with the tensegrity model., Proc. Natl. Acad. Sci. U. S. A. 98 (2001) 7765-70. doi:10.1073/pnas.141199598. 
[25] D.E. Ingber, Tensegrity I. Cell structure and hierarchical systems biology, J. Cell Sci. 116 (2003) 1157-1173. doi:10.1242/jcs.00359.

[26] N. Gavara, P. Roca-Cusachs, R. Sunyer, R. Farré, D. Navajas, Mapping cellmatrix stresses during stretch reveals inelastic reorganization of the cytoskeleton., Biophys. J. 95 (2008) 464-71. doi:10.1529/biophysj.107.124180.

[27] B. Fabry, G. Maksym, J. Butler, M. Glogauer, D. Navajas, J. Fredberg, Scaling the Microrheology of Living Cells, Phys. Rev. Lett. 87 (2001) 1-4. doi:10.1103/PhysRevLett.87.148102.

[28] P. Kollmannsberger, B. Fabry, Linear and Nonlinear Rheology of Living Cells, Annu. Rev. Mater. Res. 41 (2011) 75-97. doi:10.1146/annurev-matsci-062910100351.

[29] M.R.K. Mofrad, R.D. Kamm, Cytoskeletal Mechanics Models and Measurements, 2006. doi:10.1016/S0065-2156(08)70305-3.

[30] M.R.K. Mofrad, Rheology of the Cytoskeleton, Annu. Rev. Fluid Mech. 41 (2009) 433-453. doi:10.1146/annurev.fluid.010908.165236.

[31] H. Yamaoka, S. Matsushita, Y. Shimada, T. Adachi, Multiscale modeling and mechanics of filamentous actin cytoskeleton., Biomech. Model. Mechanobiol. 11 (2012) 291-302. doi:10.1007/s10237-011-0317-z.

[32] K.E. Kasza, C.P. Broedersz, G.H. Koenderink, Y.C. Lin, W. Messner, E. a Millman, et al., Actin filament length tunes elasticity of flexibly cross-linked actin networks., Biophys. J. 99 (2010) 1091-100. doi:10.1016/j.bpj.2010.06.025.

[33] D. Kardas, U. Nackenhorst, D. Balzani, Computational model for the cellmechanical response of the osteocyte cytoskeleton based on self-stabilizing tensegrity structures., Biomech. Model. Mechanobiol. 12 (2013) 167-83. doi:10.1007/s10237-012-0390-y.

[34] A. Vaziri, Z. Xue, R.D. Kamm, M.R. Kaazempur Mofrad, A computational study on power-law rheology of soft glassy materials with application to cell mechanics, Comput. Methods Appl. Mech. Eng. 196 (2007) 2965-2971. doi:10.1016/j.cma.2006.11.019.

[35] K.K. Mandadapu, S. Govindjee, M.R.K. Mofrad, On the cytoskeleton and soft glassy rheology., J. Biomech. 41 (2008) 1467-78. doi:10.1016/j.jbiomech.2008.02.014.

[36] P. Cañadas, V.M. Laurent, C. Oddou, D. Isabey, S. Wendling, A cellular tensegrity model to analyse the structural viscoelasticity of the cytoskeleton., J. Theor. Biol. 218 (2002) 155-173. doi:10.1006/yjtbi.3064.

[37] D.E. Ingber, Tensegrity II. How structural networks influence cellular information processing networks, J. Cell Sci. 116 (2003) 1397-1408. doi:10.1242/jcs.00360. 
[38] D.E. Ingber, Cellular tensegrity: defining new rules of biological design that govern the cytoskeleton., J. Cell Sci. 104 ( Pt 3 (1993) 613-27.

[39] D.E. Ingber, Tensegrity: the architectural basis of cellular mechanotransduction., Annu. Rev. Physiol. 59 (1997) 575-99. doi:10.1146/annurev.physiol.59.1.575.

[40] P.S.P. Silveira, A.M. Alencar, A. Majumdar, M. Lemos, J.J. Fredberg, B. Suki, Percolation in a network with long-range connections: Implications for cytoskeletal structure and function, Phys. A Stat. Mech. Its Appl. 388 (2009) 1521-1526. doi:10.1016/j.physa.2008.12.024.

[41] C.L. Dinardo, G. Venturini, E.H. Zhou, I.S. Watanabe, L.C.G. Campos, R. Dariolli, et al., Variation of mechanical properties and quantitative proteomics of VSMC along the arterial tree., Am. J. Physiol. Heart Circ. Physiol. 306 (2014) H505-16. doi:10.1152/ajpheart.00655.2013.

[42] H.T. Moriya, D.J. Colen, G.N. Maksym, A.M. Alencar, Citometria ópticomagnética de rotação: Exemplo de um método para medir as propriedades reológicas da célula, Fig.if.usp.br. (2008) 1234-1237.

[43] C.L. Dinardo, G. Venturini, S.V. Omae, E.H. Zhou, J.M. da Motta-Leal-Filho, R. Dariolli, et al., Vascular smooth muscle cells exhibit a progressive loss of rigidity with serial culture passaging., Biorheology. 49 (2012) 365-73. doi:10.3233/BIR120621.

[44] M.X.Q. Doan, A.K. Sarvari, P. Fischer-Posovszky, M. Wabitsch, Z. Balajthy, L. Fesus, et al., High content analysis of differentiation and cell death in human adipocytes., Cytometry. A. (2013). doi:10.1002/cyto.a.22333.

[45] R. Cicchi, N. Vogler, D. Kapsokalyvas, B. Dietzek, J. Popp, F.S. Pavone, From molecular structure to tissue architecture: collagen organization probed by SHG microscopy., J. Biophotonics. 6 (2013) 129-42. doi:10.1002/jbio.201200092.

[46] F. Li, Z. Yin, G. Jin, H. Zhao, S.T.C. Wong, Chapter 17: bioimage informatics for systems pharmacology., PLoS Comput. Biol. 9 (2013) e1003043. doi:10.1371/journal.pcbi.1003043.

[47] D. Rönnlund, A.K.B. Gad, H. Blom, P. Aspenström, J. Widengren, Spatial organization of proteins in metastasizing cells., Cytometry. A. 83 (2013) 855-65. doi:10.1002/cyto.a.22304.

[48] G. Chinga-Carrasco, O. Solheim, M. Lenes, a Larsen, A method for estimating the fibre length in fibre-PLA composites., J. Microsc. 250 (2013) 15-20. doi:10.1111/jmi.12012.

[49] C. a Schneider, W.S. Rasband, K.W. Eliceiri, NIH Image to ImageJ: 25 years of image analysis, Nat. Methods. 9 (2012) 671-675. doi:10.1038/nmeth.2089.

[50] S.F. Kemeny, A.M. Clyne, A simplified implementation of edge detection in MATLAB is faster and more sensitive than fast fourier transform for actin fiber 
alignment quantification., Microsc. Microanal. 17 (2011) 156-66. doi:10.1017/S143192761100002X.

[51] S. Schaub, J.-J. Meister, A.B. Verkhovsky, Analysis of actin filament network organization in lamellipodia by comparing experimental and simulated images., J. Cell Sci. 120 (2007) 1491-500. doi:10.1242/jcs.03379.

[52] J. Leemreis, A. Versteilen, Digital image analysis of cytoskeletal Fâ€• actin disintegration in renal microvascular endothelium following ischemia/reperfusion, Cytom. Part .... 978 (2006) 973-978. doi:10.1002/cyto.a.

[53] L. Huang, B.P. Helmke, A Semi-Automatic Method for Image Analysis of Edge Dynamics in Living Cells., Cell. Mol. Bioeng. 4 (2011) 205-219. doi:10.1007/s12195-010-0141-z.

[54] J.W. Fuseler, C.F. Millette, J.M. Davis, W. Carver, Fractal and image analysis of morphological changes in the actin cytoskeleton of neonatal cardiac fibroblasts in response to mechanical stretch., Microsc. Microanal. 13 (2007) 133-43. doi:10.1017/S1431927607070225.

[55] J. Adur, V.B. Pelegati, A. a de Thomaz, M.O. Baratti, L. a L. a Andrade, H.F. Carvalho, et al., Second harmonic generation microscopy as a powerful diagnostic imaging modality for human ovarian cancer., J. Biophotonics. 7 (2012) 37-48. doi:10.1002/jbio.201200108.

[56] J. Li, Q. Du, C. Sun, An improved box-counting method for image fractal dimension estimation, Pattern Recognit. 42 (2009) 2460-2469. doi:10.1016/j.patcog.2009.03.001.

[57] J.H. He, Fatalness of virus depends upon its cell fractal geometry, Chaos, Solitons \& Fractals. 38 (2008) 1390-1393. doi:10.1016/j.chaos.2008.04.018.

[58] S. Sugita, T. Matsumoto, Quantitative measurement of the distribution and alignment of collagen fibers in unfixed aortic tissues., J. Biomech. 46 (2013) 1403-7. doi:10.1016/j.jbiomech.2013.02.003.

[59] S. Deguchi, T.S. Matsui, M. Sato, Simultaneous contraction and buckling of stress fibers in individual cells., J. Cell. Biochem. 113 (2012) 824-32. doi:10.1002/jcb.23410.

[60] F. Xu, T. Beyazoglu, E. Hefner, U.A. Gurkan, U. Demirci, Automated and adaptable quantification of cellular alignment from microscopic images for tissue engineering applications., Tissue Eng. Part C. Methods. 17 (2011) 641-9. doi:10.1089/ten.TEC.2011.0038.

[61] D. Uttenweiler, C. Veigel, R. Steubing, C. Götz, S. Mann, H. Haussecker, et al., Motion determination in actin filament fluorescence images with a spatiotemporal orientation analysis method., Biophys. J. 78 (2000) 2709-15. doi:10.1016/S0006-3495(00)76815-9. 
[62] R.D. Kamm, M.R.K. Mofrad, Introduction, with the biological basis for cell mechanics, in: Cytoskelet. Mech. Model. Meas., 2006: p. 244.

[63] R.B. Phillips, J. Kondev, J. Theriot, N. Orme, H. Garcia, Physical biology of the cell, Garland Science New York, 2009.

[64] D. Boal, D.H. Boal, Mechanics of the Cell, Cambridge University Press, 2012.

[65] D. Ingber, Cellular mechanotransduction: putting all the pieces together again, FASEB J. (2006) 811-827. doi:10.1096/fj.05.

[66] S.A. Safran, N. Gov, A. Nicolas, U.S. Schwarz, T. Tlusty, Physics of cell elasticity, shape and adhesion, Phys. A Stat. Mech. Its Appl. 352 (2005) 171201. doi:10.1016/j.physa.2004.12.035.

[67] Y.C. Lin, N.Y. Yao, C.P. Broedersz, H. Herrmann, F.C. MacKintosh, D.A. Weitz, Origins of Elasticity in Intermediate Filament Networks, Phys. Rev. Lett. 104 (2010) 058101. doi:10.1103/PhysRevLett.104.058101.

[68] T. Matsumoto, K. Nagayama, Tensile properties of vascular smooth muscle cells: bridging vascular and cellular biomechanics., J. Biomech. 45 (2012) 745-55. doi:10.1016/j.jbiomech.2011.11.014.

[69] C.S. Chen, D.E. Ingber, Tensegrity and mechanoregulation: from skeleton to cytoskeleton., Osteoarthritis Cartilage. 7 (1999) 81-94. doi:10.1053/joca.1998.0164.

[70] K.Y. Volokh, On tensegrity in cell mechanics., Mol. Cell. Biomech. 8 (2011) 195-214.

[71] M. Laurentz, C. Oddouw, D. Isabeyz, A Cellular Tensegrity Model to Analyse the Structural Viscoelasticity of the Cytoskeleton Patrick Can, (2002) 155-173. doi:10.1006/yjtbi.3064.

[72] D. Stamenović, S.M. Mijailovich, I.M. Tolić-Nørrelykke, J. Chen, N. Wang, Cell prestress. II. Contribution of microtubules., Am. J. Physiol. Cell Physiol. 282 (2002) C617-24. doi:10.1152/ajpcell.00271.2001.

[73] L. Blanchoin, R. Boujemaa-Paterski, C. Sykes, J. Plastino, Actin dynamics, architecture, and mechanics in cell motility., Physiol. Rev. 94 (2014) 235-63. doi:10.1152/physrev.00018.2013.

[74] T.D. Pollard, J.A. Cooper, Actin, a central player in cell shape and movement., Science. 326 (2009) 1208-12. doi:10.1126/science.1175862.

[75] H.A. Barnes, J.F. Hutton, K. Walters, An introduction to rheology, Elsevier, 1989.

[76] T.M. Squires, T.G. Mason, Fluid Mechanics of Microrheology, Annu. Rev. Fluid Mech. 42 (2010) 413-438. doi:10.1146/annurev-fluid-121108-145608. 
[77] P.A. Tipler, G.P. Mosca, Física para cientistas e engenheiros: Mecânica, 2009.

[78] Y.H. Lin, Polymer Viscoelasticity: Basics, Molecular Theories, Experiments and Simulations, World Scientific, 2011.

[79] M. Puig de Morales, E. Millet, B. Fabry, D. Navajas, N. Wang, J.P. Butler, et al., Cytoskeletal mechanics in adherent human airway smooth muscle cells: probe specificity and scaling of protein-protein dynamics., Am. J. Physiol. Cell Physiol. 287 (2004) C643-54. doi:10.1152/ajpcell.00070.2004.

[80] R.C. Gonzalez, R.E. Woods, S.L. Eddins, Digital Image Processing Using Matlabtm, Digit. Image Process. Using Matlabtm, by Rafael C. Gonzalez, Richard E. Woods Steven L. Eddins. ISBN 0-13-008519-7. Publ. by Pearson Prentice Hall, Up. Saddle River, NJ USA, 2004. 1 (2004) 1-11.

[81] J.C. Russ, The image processing handbook, CRC press, 2010.

[82] D. Shotton, Confocal scanning optical microscopy and its applications for biological specimens, J. Cell Sci. (1989).

[83] R.H. Webb, Confocal optical microscopy, Reports Prog. Phys. 59 (1999) 427471. doi:10.1088/0034-4885/59/3/003.

[84] C.L. Smith, Basic confocal microscopy., Curr. Protoc. Neurosci. Chapter 2 (2011) Unit 2.2. doi:10.4081/ejh.2012.br3.

[85] T. Wilson, Confocal microscopy, Acad. Press London, Etc. (1990). doi:10.1081/E-EBBE-120024153.

[86] B. Albert, A. Johnson, J. Lewis, M. Raff, K. Roberts, P. Walter, Molecular Biology of the Cell, 2008.

[87] B.A. Griffin, Specific Covalent Labeling of Recombinant Protein Molecules Inside Live Cells, Science (80-. ). $281 \quad$ (1998) 269-272. doi:10.1126/science.281.5374.269.

[88] N. Soh, Selective Chemical Labeling of Proteins with Small Fluorescent Molecules Based on Metal-Chelation Methodology, Sensors. 8 (2008) 10041024. doi:10.3390/s8021004.

[89] D.J. Fishkind, Y.L. Wang, Orientation and three-dimensional organization of actin filaments in dividing cultured cells., J. Cell Biol. 123 (1993) 837-48.

[90] K. Wong, A. Chekima, Palmprint identification using Sobel operator, Robot. Vis. (2008) 1338-1341. doi:10.1109/ICARCV.2008.4795716.

[91] A.R. Khalid, R. Paily, FPGA Implementation of high speed and low power architectures for image segmentation using Sobel operators, J. Circuits, Syst. Comput. 21 (2012) 1250050. doi:10.1142/S0218126612500508. 
[92] O.R. Vincent, O. Folorunso, A Descriptive Algorithm for Sobel Image Edge Detection, in: Proc. Informing Sci. IT Educ. Conf. 2009, 2009: pp. 1-11.

[93] M. Yoshigi, E.B. Clark, H.J. Yost, Quantification of stretch-induced cytoskeletal remodeling in vascular endothelial cells by image processing., Cytometry. A. 55 (2003) 109-18. doi:10.1002/cyto.a.10076.

[94] W.G.W. Gao, X.Z.X. Zhang, L.Y.L. Yang, H.L.H. Liu, An improved Sobel edge detection, Comput. Sci. Inf. Technol. (ICCSIT), 2010 3rd IEEE Int. Conf. 5 (2010). doi:10.1109/ICCSIT.2010.5563693.

[95] Z. Jin-yu, C. Yan, H. Xian-xiang, Edge detection of images based on improved Sobel operator and genetic algorithms, 2009 Int. Conf. Image Anal. Signal Process. (2009) 31-35. doi:10.1109/IASP.2009.5054605.

[96] L. Lacasa, J. Gómez-Gardeñes, Correlation Dimension of Complex Networks, Phys. Rev. Lett. 110 (2013) 168703. doi:10.1103/PhysRevLett.110.168703.

[97] W. He, H. Xiao, X. Liu, Numerical Simulation of Human Systemic Arterial Hemodynamics Based on a Transmission Line Model and Recursive Algorithm, J. Mech. Med. Biol. 12 (2012) 1250020. doi:10.1142/S0219519411004587.

[98] P. Taylor, G. Schliecker, Advances in Physics Structure and dynamics of cellular systems, (2010).

[99] K.J. Schrenk, N. a M. Araújo, J.S. Andrade, H.J. Herrmann, Fracturing ranked surfaces., Sci. Rep. 2 (2012) 348. doi:10.1038/srep00348.

[100] O. Scholder, Anti-Red Bond Calculation Algorithm in Percolation, Int. J. Mod. Phys. C. 20 (2009) 267-272. doi:10.1142/S0129183109013595.

[101] J.P. Clerc, L. Zekri, N. Zekri, Statistical and finite size scaling behavior of the red bonds near the percolation threshold, Phys. Lett. A. 338 (2005) 169-174. doi:10.1016/j.physleta.2005.02.049.

[102] P.S. Addison, Fractals and chaos: an illustrated course, CRC Press, 1997.

[103] A.L. Barabasi, H.E. Stanley, Fractal concepts in surface growth, 1995, Cambridge Univ. Press. Cambridge, Halpin-Healy T., Zhang YC, Phys. Rep. 254 (1995) 215.

[104] A. Kapitulnik, A. Aharony, G. Deutscher, D. Stauffer, Self similarity and correlations in percolation, J. Phys. A. Math. Gen. 16 (1983) L269-L274. doi:10.1088/0305-4470/16/8/003.

[105] S. Kirkpatrick, Percolation and Conduction, Rev. Mod. Phys. 45 (1973) 574-588. doi:10.1103/RevModPhys.45.574.

[106] A. Aharony, A.B. Harris, Multifractal localization, Phys. A Stat. Mech. Its Appl. 191 (1992) 365-378. doi:10.1016/0378-4371(92)90553-3. 
[107] K. Binder, W. Kob, Glassy materials and disordered solids: An introduction to their statistical mechanics, World Scientific, 2011.

[108] D. Stauffer, A. Aharony, Introduction to percolation theory, Taylor and Francis, 1994.

[109] S. Alonso, M. Bär, Reentry Near the Percolation Threshold in a Heterogeneous Discrete Model for Cardiac Tissue, Phys. Rev. Lett. 110 (2013) 158101. doi:10.1103/PhysRevLett.110.158101.

[110] D. Stauffer, Scaling theory of percolation clusters, Phys. Rep. 54 (1979) 1-74. doi:10.1016/0370-1573(79)90060-7.

[111] J.M. Hammersley, others, Percolation processes. Lower bounds for the critical probability, Ann. Math. Stat. 28 (1957) 2.

[112] N. Wang, Z. Suo, Long-distance propagation of forces in a cell, Biochem. Biophys. Res. Commun. 328 (2005) 1133-1138.

[113] S.A. Shah, P. Santago, B.K. Rubin, Quantification of biopolymer filament structure., $\quad$ Ultramicroscopy. $\quad 104 \quad$ (2005) 244-54. doi:10.1016/j.ultramic.2005.04.007.

[114] G. Chinga, P.O. Johnsen, R. Dougherty, E.L. Berli, J. Walter, Quantification of the 3D microstructure of SC surfaces., J. Microsc. 227 (2007) 254-65. doi:10.1111/j.1365-2818.2007.01809.x.

[115] H. Parameswaran, A. Majumdar, S. Ito, A.M. Alencar, B. Suki, Quantitative characterization of airspace enlargement in emphysema., J. Appl. Physiol. 100 (2006) 186-93. doi:10.1152/japplphysiol.00424.2005.

[116] N. Otsu, A Threshold Selection Method from Gray-Level Histograms, IEEE Trans. Syst. Man. Cybern. 9 (1979) 62-66. doi:10.1109/TSMC.1979.4310076. 


\section{Anexo I}

\section{Cultura e isolamento de células}

Fragmentos das artérias aorta abdominal, femoral, renal, mamária, carótida, aorta torácica e coronária foram coletados de quatro porcos fêmeas, de mesma idade e peso. Os fragmentos dos vasos coletados foram usados para isolar as células vasculares de músculo liso (CVML) utilizando a técnica de explante primário. Nesta técnica as células são extraídas do tecido do doador e isoladas antes da primeira subdivisão. Geralmente, utiliza-se células em crescimento, devido a sua habilidade em fazer migração e proliferação, após ser subcultivada.

Os fragmentos dos vasos tiveram seu lúmen aberto e foram cortados em pequenos pedaços ( $3 \mathrm{~mm}$ x $3 \mathrm{~mm}$ ). O lúmen celular é a parte viva da célula que consiste da: membrana plasmática, citoplasma e núcleo. Em seguida, os fragmentos foram colocados em seis recipientes (pocinho), previamente revestidas com gelatina suínocutânea a 3\%. O meio de cultura utilizado consiste de alta - glicose Dulbecco's Modified Eagle Medium - DMEM (Invitrogen®) suplementado com 20\% de soro bovino fetal (Gibco®), 100 unit $\mathrm{ml}^{-1}$ de penicilina e $100 \mu \mathrm{g} \mathrm{ml}^{-1}$ de estreptomicina (Invitrogen ${ }^{\circledR}$ ). As CVML foram caracterizadas com microscopia confocal (positivo para actina-alfa, negativo para fator von-Willerbrand) e expandida para as passagens subsequentes em uma porção de 1:2.

Marcação da actina e aquisição da imagem

- Até a fixação das células, a placa deve ser mantida sobre gelo; 
- Retira-se o meio de cultura dos poços e lava-se a célula 10 vezes, com PBS (o PBS deve ser colocado e, ao mesmo tempo, retirado dos poços com o auxílio de duas pipetas de $10 \mathrm{ml}$ );

- Bloqueio dos sítios inespecíficos das células com uma solução de PBS/BSA (albumina) - Electron Microscopy Science (EMS) 1\% por 20 minutos;

- Lavar as células com PBS, da maneira já citada;

- Incubação com anticorpo primário anti-CD11b biotilinado (BD/Pharmingen) deluído em PBS/BSA 1\%, durante 40 minutos;

- Lavar as células com PBS, da maneira já citada;

- Fixar as células. Para este procedimento, as lamínulas devem ser transferidas para uma placa de cultivo nova, para se evitar a presença de restos celulares. Antes da transferência das lamínulas deve se colocar 500 $\mu 1$ de PBS em cada poço para evitar a secagem do material;

- Retira-se o PBS e se adiciona paraformaldeído (PFA) 2\% em PBS, por 30 minutos a temperatura ambiente;

- Lavar novamente as células com PBS, da maneira já citada;

- Bloquear os radicais aldeído do PFA (para evitar a auto-fluorescência do

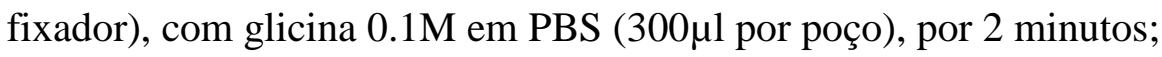

- Lavar as células com PBS, da maneira já citada;

- Nesta etapa o procedimento pode ser interrompido, desde que as células sejam mantidas a $4^{\circ} \mathrm{C}$ e os poços estejam bem preenchidos com PBS;

- Novo bloqueio dos sítios inespecíficos das células com a solução de PBS/BSA $1 \%$ por 20 minutos;

- Lavar as células com PBS, da maneira já citada;

- Incubação com o anticorpo anti-porção Fc (Fc block - BD-Pharmingen), para evitar marcação inespecífica, diluído em PBS/BSA $1 \%$ durante 40 minutos, na concentração fina de $1 \mu \mathrm{g} \%$;

- Como segundo passo se usa estreptavidina conjugada com o fluorocromo ficoeritrina (PE), diluída em PBS/BSA 1\% durante 40 minutos no escuro, na concentração final de $1 \mu \mathrm{g} \%$. Não é preciso efetuar nova lavagem antes deste procedimento, tendo em vista que, antes da incubação, a solução de estreptavidina foi centrifugada por 10 minutos a $10.000 \mathrm{rpm}$, para evitar precipitados; 
- Lavar as células com PBS, da maneira já citada;

- Retirar as lamínulas da placa de cultivo, mergulhar rapidamente em água destilada e efetuar a montagem;

- Montagem das lâminas com resina Vectashield contendo o corante nuclear DAPI (4.6 - diamidino - 2 - fenilindole, dihidroxicloride) (Vector) na concentração de $1.5 \mu \mathrm{g} / \mathrm{ml}$

- Manutenção das lamínulas a $4^{\circ} \mathrm{C}$ para secagem. Após a secagem, as lamínulas devem ser vedadas com esmalte e mantidas no escuro, a $4{ }^{\circ} \mathrm{C}$, até a vizualização do material ao microscópio confocal.

As imagens fluorescentes estudadas foram adquiridas usando um microscópio confocal de varredura a laser da Zeiss LSM 510 META.

OBS: As céluas não podem secar em nenhum momento do experimento. 